\title{
Analysis of economic diversification and financial liquidity effects in sustainably managed forest enterprises
}

\author{
DISSERTATION \\ zur Erlangung des Doktorgrades (Dr. forest.) \\ der Fakultät für Forstwissenschaften und Waldökologie \\ der Georg-August-Universität Göttingen
}

vorgelegt von

Johannes Carl Wildberg

geboren am 14. Dezember 1989 in Wedel (Holstein) 
1. Gutachter: Prof. Dr. Bernhard Möhring

2. Gutachterin: Prof. Dr. Carola Paul

Tag der mündlichen Prüfung: 19. August 2021 


\section{Acknowledgements}

This thesis was mainly written during my time as a research assistant at the Department of Forest Economics. Thusly, this thesis was funded in support of academic qualification at the University of Göttingen.

First, I would like to thank:

My supervisor Prof. Dr. Bernhard Möhring - your expertise was invaluable for me to find the right focus for my research and I am grateful for the discussions we had that lead to the completion of this thesis. I thank you for the opportunity you gave me to work for the department as your assistant and lecturer and for supporting me in my travels abroad.

My second supervisor Prof. Dr. Carola Paul - your supportive, targeted and solutionoriented feedback has been of great help and your positive attitude and success towards publishing in scientific journals has been an inspiration. Thank you for accepting me as your doctoral student without hesitation.

My third supervisor Prof. Dr. Matthias Dieter - I highly appreciate the good talks we had during our colloquia and in Brazil.

I also particularly thank:

Dr. Roman Koster for being a most supportive and empathic colleague and friend with incredible talents.

Dr. Fabian Böttcher for your quick-mindedness and readiness to help out in both professional and personal matters.

Dr. Kai Husmann for being there when I needed an experienced researcher when things got complicated.

Dr. Markus Dög for being a team-player and an enjoyable colleague to work with.

Additionally I would like to thank: Gundula von Arnim, Ferdinand von Plettenberg, Dr. Moritz von Blomberg, Jasper Fuchs, Volker von Groß - it was a pleasure having you around!

My highest gratitude goes to Laura who stood by my side during good times and bad. 


\section{Contents}

Figures

Tables

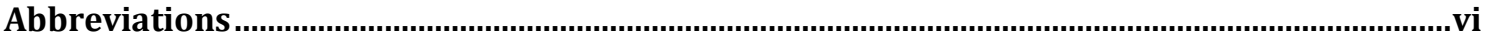

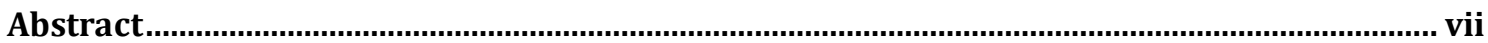

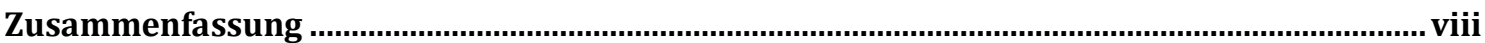

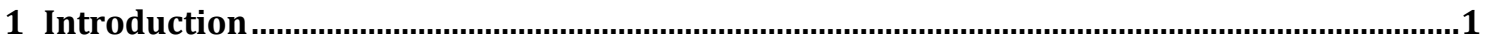

1.1 Introduction of the individual topics and studies.............................................................

1.1.1 Forest accountancy data and empirical diversification effects .............................................. 2

1.1.1.1 Forest accountancy data networks...................................................................... 2

1.1.1.2 Empirical tree species diversification effects......................................................... 3

1.1.2 Financing, liquidity and sustainability in forest enterprises .................................................. 3

1.1.2.1 Financing in times of calamity............................................................................ 3

1.1.2.2 Liquidity and sustainability in forest enterprises ................................................... 3

2 Analysis of empirical tree species diversification effects with the use of forest accountancy data network data

2.1 Study 1: Analysis of a long-term Forest Accountancy Network to Support Management and Controlling.

2.1.1 Background and objective ....................................................................................................... 4

2.1.2 Methodology and main results........................................................................................... 5

2.2 Study 2: Empirical analysis of the economic effect of tree species diversity based on

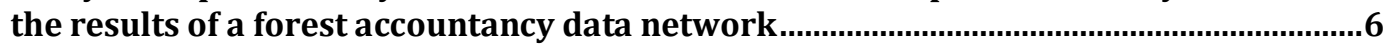

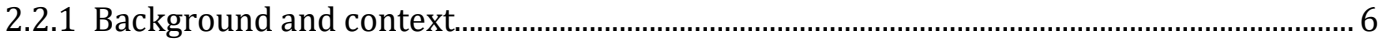

2.2.2 Methodology and main results...................................................................................................

3 Financing, liquidity and sustainability in forest enterprises .......................................... 13

3.1 Study 3: Liquiditätssicherung privater Forstbetriebe bei Kalamität............................... 13

3.1.1 Background and context...............................................................................................................13

3.1.2 Methodology and main results................................................................................................13

3.2 Study 4: Continuous timber harvest - Costly restriction or profitable solution? ........ 16

3.2.1 Background and context......................................................................................................

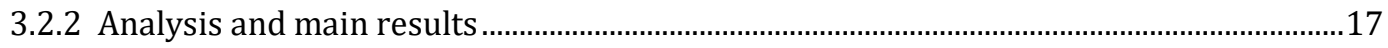

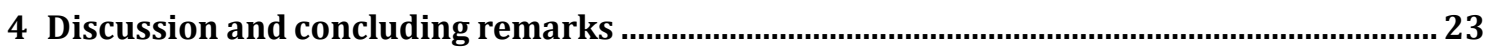

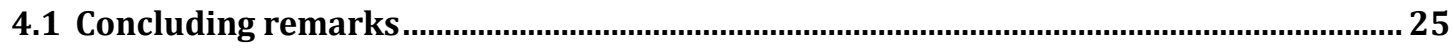




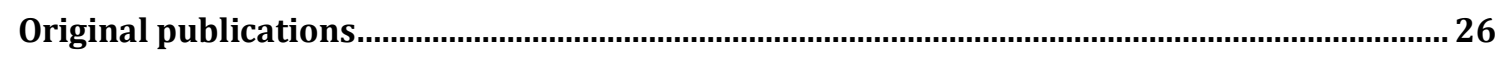

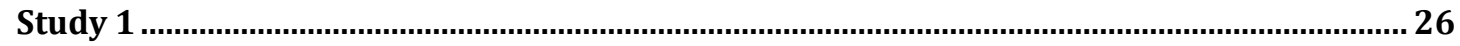

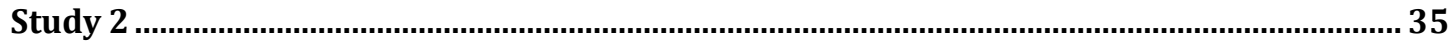

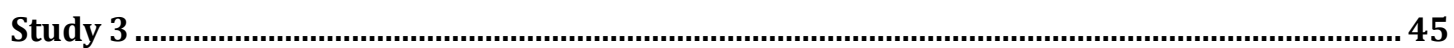

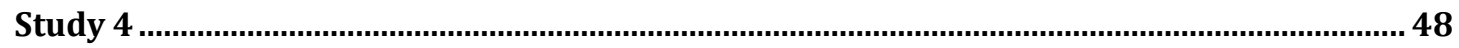

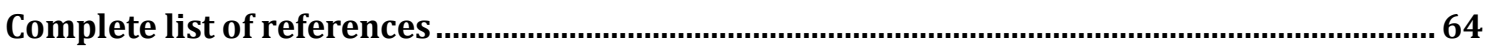




\section{Figures}

Fig. 1. Allocation of tree species groups in the forest enterprises of the FAN Westfalen-Lippe........ 6

Fig. 2 Development of the mean annual contribution margins of the forest enterprises grouped by consultancy circles.

Fig. 3. Mean vs. standard deviation of the annual contribution margins of the forest enterprises grouped by consultancy circles.

Fig. 4 Development of the mean annual contribution margins of the tree species groups...............9

Fig. 5. Mean vs. standard deviation of the annual contribution margins per tree species area of the tree species groups in the forest enterprises.

Fig. 6. Linear combination of return vs. nonlinear combination of risk.

Fig. 7 Undetrended and detrended mean development of the annual contribution margins of the tree species groups of the forest enterprises.

Fig. 8 Underlying natural (a-b) and economic (c) functions of the forest stand production model.

Fig. 9. Net soil rent for varying forest stand rotation ages and interest rates. 18

Fig. 10. Development of the net timber income resulting from the periodic transition (left) and the continuous transition (right)

Fig. 11. Combination of forest enterprise and financial investment. ... 20

Fig. 12. Interest rate curve for varying intensities of capital market imperfection. 21

Fig. 13. Relative profitability, expressed by the maximum annual payout, of the periodic vs. the continuous forest enterprise transition for varying intensities of capital market imperfection. 


\section{Tables}

Tab. 1 Structural overview of the topics and studies that comprise the thesis...................................... 2

Tab. 2 List of operational objectives of the forest enterprises arranged in descending order of priority (over all enterprises).

14

Tab. 3 List of possible measures to avoid expenses, increase revenue and forest policy instruments in descending order of priority (over all enterprises). 15

Tab. 4. Net present value and annuity of the net timber income resulting from the periodic and continuous forest enterprise transitions. 


\section{Abbreviations}

BMEL

Bundesministerium für Ernährung und Landwirtschaft

CM I Contribution margin I

FAN. Forest accountancy data network FPO-rule Faustmann-Pressler-Ohlin rule ha Hectare LEV ... Land expectation value MAP. Maximum annual pay out

NPV Net present value 


\section{Abstract}

Sustainably managed forest enterprises are required to apply and adapt strategies to be able to distribute economic risk and secure financial liquidity. In this context, this thesis analyzes the possibilities of economic effects of tree species diversity in forest enterprises using empirical data. Furthermore, this thesis addresses the current issues of financial liquidity in forest enterprises and subsequently examines the importance of continuity and even flow of income to sustain forest operations.

Part of the empirical analysis of the thesis is based on the data of a forest accountancy data network. First, the possibilities in evaluating and analyzing operational forest enterprise data is illustrated with examples from the tasks in accounting and examples in benchmarking. Then, the time series data of the forest accountancy data network is analyzed in regard to diversification effects of tree species diversity. An indicated correlation between tree species diversity in forest enterprises and decreased volatility of annual net return from timber production is found. Regarding the diversification effect, the time series data show, that the volatility of net return from timber production was decreased in all forest enterprise compared to the sum of the weighted net return from the underlying tree species groups. This effect was highest in the forest enterprises that also generated the lowest enterprise net return. Furthermore, it is shown, that non-stationary development of the time series data needs to be considered in the interpretation of diversification effects.

Furthermore, this thesis addresses the topic of financial liquidity in forestry, initially from the perspective of private forest enterprises following recent calamity events. It is shown that forest enterprises were heavily impacted by calamities resulting in losses of income from timber production. Subsequently possibilities to avoid costs, increase revenue and secure liquidity are identified.

Lastly, the question of the optimal rotation age is analyzed under the influence of different capital market assumptions. It is shown that the profitability of irregular timber income is a consequence of the assumption of constant interest rates in a perfect capital market. By shifting the perspective of a perfect capital market to an imperfect capital market with differing borrowing and lending rates, the common preference of forest enterprises for sustainability in the sense of a steady flow of income can be explained. 


\section{Zusammenfassung}

Nachhaltig bewirtschaftete Forstbetriebe müssen Strategien anwenden und anpassen, um Risiko zu streuen und die finanzielle Liquidität sichern zu können. In diesem Zusammenhang werden in dieser Arbeit die wirtschaftlichen Auswirkungen der Baumartenvielfalt in Forstbetrieben anhand empirischer Daten analysiert. Des Weiteren wird in dieser Arbeit die aktuelle Problematik der finanziellen Liquidität in Forstbetrieben behandelt und anschließend die Bedeutung von Kontinuität und gleichmäßigem Einkommen zur Aufrechterhaltung des Forstbetriebes analysiert.

Ein Teil der empirischen Analyse der Arbeit basiert auf den Daten eines forstlichen Betriebsvergleichs. Zunächst werden die Möglichkeiten der Auswertung und Analyse der Forstbetriebsdaten anhand von Beispielen aus dem Controlling dargestellt. Anschließend werden die Zeitreihendaten des forstlichen Betriebsvergleichs im Hinblick auf Effekte der Baumartendiversität untersucht. Es wird ein Zusammenhang zwischen der Baumartendiversität in Forstbetrieben und einer verringerten Volatilität des jährlichen Deckungsbeitrags aus der Holzproduktion gefunden. Hinsichtlich des Diversifikationseffektes zeigen die Zeitreihendaten, dass die Volatilität des Deckungsbeitrages aus der Holzproduktion in allen Forstbetrieben im Vergleich zur Summe der gewichteten Deckungsbeiträge aus den zugrundeliegenden Baumartengruppen verringert wurde. Dieser Effekt war bei den Forstbetrieben am höchsten, die auch den niedrigsten durchschnittlichen betrieblichen Deckungsbeitrag erwirtschafteten. Weiterhin wird gezeigt, dass die nicht-stationäre Entwicklung der Zeitreihendaten bei der Interpretation von Diversifikationseffekten berücksichtigt werden muss.

Des Weiteren befasst sich diese Arbeit mit dem Thema der finanziellen Liquidität in der Forstwirtschaft, zunächst aus der Perspektive der privaten Forstbetriebe nach den jüngsten Kalamitätsereignissen. Es wird gezeigt, dass die Forstbetriebe durch die Kalamitätsereignisse stark betroffen waren, was zu Einkommensverlusten aus der Holzproduktion führte. Anschließend werden Möglichkeiten zur Einsparung von Kosten, der Umsatzsteigerung und der Liquiditätssicherung aufgezeigt.

Abschließend wird die Frage nach der optimalen Umtriebszeit unter dem Einfluss verschiedener Kapitalmarktannahmen analysiert. Es wird gezeigt, dass die relative Vorteilhaftigkeit unregelmäßiger Holzerträge eine Folge der Annahme konstanter Zinssätze in einem vollkommenen Kapitalmarkt ist. Durch einen Wechsel der Prämissen des vollkommenen Kapitalmarktes auf ein Modell des unvollkommenen Kapitalmarktes mit unterschiedlichen Soll- und Habenzinsen wird gezeigt, dass durch die Änderung der Kapitalmarktprämisse das verbreitet vorzufindende Bestreben der Forstbetriebe nach Nachhaltigkeit im Sinne eines stetigen Zahlungsstromes ökonomisch erklärt/begründet werden kann. 


\section{Introduction}

Forests and forest enterprises are complex systems that are required to consider and deal with increasing biological, social and economic demands (Gutsche, 2014, p. 1; Möhring, 1994, p. 2f.). Forestry is susceptible to a range of climate change induced (Hanewinkel et al., 2013) and market (Holthausen, 2006) risks, which can result in loss of income (e.g. Borchert, 2004) or devaluation of assets (e.g. Möhring et al., 2021). Additionally, sustainable forest management is subject to long production periods, which enhances the difficulty in making rational decisions to ensure profitability.

According to the first edition of Speidel $(1967$, p. 16) the purpose of forest economics is to evaluate economic profitability with respect to operational objectives. Profitability evaluation can be based on past processes to examine operational behavior. Additionally, the possibilities to ensure optimal operational configuration in the future need to be considered. This requires to evaluate the natural, technical and economic situation in the forest enterprises (Speidel, 1967, p. 17) using both long-term and current empirical data. In this regard, the purpose of forest economics is also to aid in decision making (see Möhring, 1994, p. 1). By the use of profitability calculations, theoretical models and simulations, which analyze fundamental interdependencies, indications for solutions to empirical problems can be derived.

The objective of this thesis is to empirically record the significance of diversification as an expression of distributing risk and the importance of liquidity as an expression of economic sustainability in the sense of continuity or as a prerequisite for maintaining forest operations. This thesis comprises empirical current and time series data to evaluate the natural and economic situation in forest enterprises. Furthermore, the thesis analyzes theoretical models and investment alternatives using both empirical data and model simulations.

\subsection{Introduction of the individual topics and studies}

The following Tab. 1 provides an overview on the contents and structure of the cumulative thesis. The thesis addresses the topics of diversification effects, financing and liquidity in forest enterprises in four individual studies that have been summarized into two topics. 
Tab. 1 Structural overview of the topics and studies that comprise the thesis.

\begin{tabular}{|c|c|c|}
\hline & Topic I & Topic II \\
\hline & $\begin{array}{l}\text { Analysis of empirical tree species } \\
\text { diversification effects with the use } \\
\text { of forest accountancy data } \\
\text { network data }\end{array}$ & $\begin{array}{l}\text { Financing, liquidity and } \\
\text { sustainability in forest enterprises }\end{array}$ \\
\hline Empirical studies & Study 1 (Dög et al., 2018) & Study 3 (Arnim et al., 2020) \\
\hline $\begin{array}{l}\text { Analyzing the economic } \\
\text { situation in forest } \\
\text { enterprises }\end{array}$ & $\begin{array}{l}\text { The use of FAN-data to support } \\
\text { tasks in accounting and } \\
\text { controlling }\end{array}$ & $\begin{array}{l}\text { Measures to secure financial } \\
\text { liquidity of forest enterprises in } \\
\text { times of calamity }\end{array}$ \\
\hline $\begin{array}{l}\text { Theoretical background } \\
\text { studies }\end{array}$ & Study 2 (Wildberg \& Möhring, 2019) & Study 4 (Wildberg \& Möhring, 2021) \\
\hline $\begin{array}{l}\text { Analyzing theoretical } \\
\text { concepts and fundamental } \\
\text { interrelations }\end{array}$ & $\begin{array}{l}\text { Empirical diversification effects of } \\
\text { tree species diversity }\end{array}$ & $\begin{array}{l}\text { Liquidity and sustainability under } \\
\text { varying capital market conditions }\end{array}$ \\
\hline & & \\
\hline
\end{tabular}

The studies 1 and 3 are of empirical nature, while the studies 2 and 4 examine theoretical concepts using empirical data, model simulations and profitability calculations. While studies 1 and 2 share the same set of empirical data, study 3 and 4 are connected through the topics of financing and liquidity from two different perspectives.

The following sections 1.1.1 - 1.1.2 will give a short introduction to the studies and state the author contribution of each publication. In the consecutive sections $2-4$ the results and discussions are based on the underlying publications and they will not be further cited. The figures and tables that have either been taken from the publications directly or adapted are marked with a reference accordingly.

\subsubsection{Forest accountancy data and empirical diversification effects}

\subsubsection{Forest accountancy data networks}

The first study "Analysis of a long-term Forest Accountancy Network to Support Management and Controlling" (Dög et al., 2018) demonstrates the applicability of forest accountancy data in forest enterprise management and accounting. The study outlines the major tasks involved in forest management and accounting by applying the time series data of the forest accountancy data network (FAN) Westfalen-Lippe. The data from 1969 to 2018 show the development of financial and operational figures, which are used to describe, explain and interpret the operational situation in the network's participating private and communal forest enterprises. Besides determining the annual felling amount or the financeable working hours for example, the data of the FAN Westfalen-Lippe can be used to calculate the economic contribution of the individual tree species groups. This part of the data is the basis for the consecutive second study. 
The authors Markus Dög, Johannes Wildberg and Bernhard Möhring were involved in publishing this study. Markus Dög conducted the analysis and wrote the article together with Johannes Wildberg. Bernhard Möhring supervised the publication process.

\subsubsection{Empirical tree species diversification effects}

The second study "Empirical analysis of the economic effect of tree species diversity based on the results of a forest accountancy data network" (Wildberg \& Möhring, 2019) applies the theoretical concept of the portfolio diversification effect to the FAN Westfalen-Lippe data. The study follows two major objectives: To measure the empirical diversification effect of tree species diversity in forest enterprises and to validate how the time series data match the premises behind the theoretical concept of the diversification effect specifically regarding the assumption of stationarity of time series.

The authors Johannes Wildberg and Bernhard Möhring were involved in publishing this study. Both authors developed the idea and the conceptual approach of the study. Johannes Wildberg wrote the article under the supervision of Bernhard Möhring.

\subsubsection{Financing, liquidity and sustainability in forest enterprises}

\subsubsection{Financing in times of calamity}

The third study "Liquiditätssicherung privater Forstbetriebe bei Kalamität" (Arnim et al., 2020 ) is an empirical analysis on the financial situation in private forest enterprises after the calamity years 2018/19 in Germany.

The study is based on a Master's thesis by Gundula von Arnim (Arnim, 2020), which was supervised by Johannes Wildberg and Bernhard Möhring. The study was written by Gundula von Arnim with the support of Johannes Wildberg and was supervised by Bernhard Möhring. Note that the study will also be published in Arnim et al. (2021, unpublished).

\subsubsection{Liquidity and sustainability in forest enterprises}

The fourth study "Continuous timber harvest - costly restriction or profitable solution?" (Wildberg \& Möhring, 2021) analyzes how capital market assumptions influence the interpretation of the optimal rotation age and harvesting pattern. Here the profitability of a periodic and a continuous normal forest enterprise transition are evaluated under the assumption of both constant and differing borrowing and lending rates.

The fourth study was conducted by Johannes Wildberg and Bernhard Möhring. Both Johannes Wildberg and Bernhard Möhring developed the topic and model simulation. Johannes Wildberg wrote the article under the supervision of Bernhard Möhring. 
Analysis of empirical tree species diversification effects with the use of forest accountancy data network data

\section{Analysis of empirical tree species diversification effects with the use of forest accountancy data network data}

The first two studies of this thesis apply the data of the FAN Westfalen-Lippe. First a general introduction to the data is given, providing an overview on the possibilities to analyze the data regarding to the tasks involved in forest enterprise accounting. The second study specifically focuses on the empirical diversification effect of tree species diversity in the forest enterprises of the FAN Westfalen-Lippe.

\subsection{Study 1: Analysis of a long-term Forest Accountancy Network to Support Management and Controlling}

\subsubsection{Background and objective}

Forest accountancy data networks are typically used for regular reporting and forest economic monitoring (Kaul \& Leefken, 2001). The data is applied to evaluate natural development and economic activity (Möhring \& Dög, 2019) and allows for comparing operational results between forest enterprises given that the accounting standards follow a similar system (Kaul \& Leefken, 2001). FANs are particularly popular in the "DACH-region" (Germany, Austria and Switzerland) (Sekot et al., 2011; Toscani, 2016, p. 1) where they are not only a tool for controlling, but also for benchmarking (see Sekot, 2008) and future planning. FANs provide an infrastructure for empirical research (Sekot, 2017) and the data have been applied to many different fields of research. These include efficiency analysis using Data Envelopment Analysis (Sekot \& Hoffmann, 2007), the contribution of tree species (Wilhelm \& Möhring, 2014), non-timber forest products (Toscani \& Sekot, 2015) and diversification of non-timber forest products (Ungerböck et al., 2015), forest road infrastructure (Toscani et al., 2020) and other topics revolving around sustainable multiple use forestry (see Toscani \& Sekot, 2018).

The FAN Westfalen-Lippe provides the longest time series in the DACH-region with an average of 35 private and communal participating forest enterprises (Möhring \& Dög, 2019). As a cooperation project between the federal state of North Rhine-Westphalia, the Landesbetrieb Wald $u$. Holz NRW, the Forest Farmers Association NRW and the University of Göttingen, the FAN has collected accountancy data since 1969 (Möhring \& Dög, 2019). The data of the FAN Westfalen-Lippe contribute to the national monitoring of forest enterprises in the Testbetriebsnetz Forst of the Bundesministerium für Ernährung und Landwirtschaft (BMEL) (Möhring \& Dög, 2019). The forest enterprises of the FAN Westfalen-Lippe are mainly located in Northrhine-Westfalia but also Lower Saxony and Hesse. The enterprises are separated into three consultancy circles depending on their dominating tree species group of spruce, hardwood or pine, making it easier to compare enterprises of similar operational orientation (Kaul \& Leefken, 2001). The objective of this study was to demonstrate how data of FANs can contribute to the tasks of internal accounting by providing specific empirical examples (see also Möhring \& Dög, 2019). In the scope of this thesis, study 1 provides an introduction to study 2 (section 2.2) where the empirical diversification effects in the forest enterprises of the FAN Westfalen-Lippe are analyzed. 
Analysis of empirical tree species diversification effects with the use of forest accountancy data network data

\subsubsection{Methodology and main results}

\section{Task 1: Description}

Various indicators and economic figures can be applied to describe the past and current situation and economic activity of a forest enterprise. One of the most important indicators for economic activity includes the annual felling amount (Dög \& Möhring, 2017). The amount of felled timber in the spruce enterprises mostly exceeded that of the other two enterprise types. The amounts of timber felled in the forest enterprises peaked during calamity years for example in 1990 and 2007. Peaks in timber harvest were subsequently followed by a year with lower timber harvests. The spruce enterprises were most affected by volatile timber harvests. The amounts of felled timber are directly reflected in the operating costs and revenues for timber production, which are applied to determine the annual operational net income.

\section{Task 2: Explanation}

The second task of accounting is to interpret results in the data in order to identify factors for success and potentials for operational efficiency. This includes for example calculating the working hours that can be financed with selling a solid cubic meter of timber. In the data of the FAN Westfalen-Lippe, the financeable working hours show a decreasing trend over time. It can be seen for example, that the effect of mechanization and rising labor costs and varying timber prices decreases the financeable working hours.

\section{Task 3: Decision Making}

The third task is designated to determine the factors for decision making, which are based on the factors of success. The third task includes determining the financial contribution of the individual tree species groups. This requires shifting the focus from the level of the forest enterprise to the individual tree species level. It was identified for example, that the spruce harvests (solid cubic meters per hectare tree species area) have decreased over the past years. Together with oak the spruce species returned the highest prices per cubic meter. Regarding the contribution per tree species area, the data revealed that spruce contributed the most to the enterprises followed by the broadleaf species and the pine. 
Analysis of empirical tree species diversification effects with the use of forest accountancy data network data

\subsection{Study 2: Empirical analysis of the economic effect of tree species diversity based on the results of a forest accountancy data network}

\subsubsection{Background and context}

As described in study 1 of section 2.1 the forest enterprises of the FAN Westfalen-Lippe are separated into consultancy circles depending on their dominating tree species group. However, this information alone provides no indication on the areal proportions of all tree species groups within the same forest enterprise. Fig. 1 shows the distribution of the tree species groups in the individual enterprises. This provides a first idea on how diversified the tree species composition in each forest enterprise is.

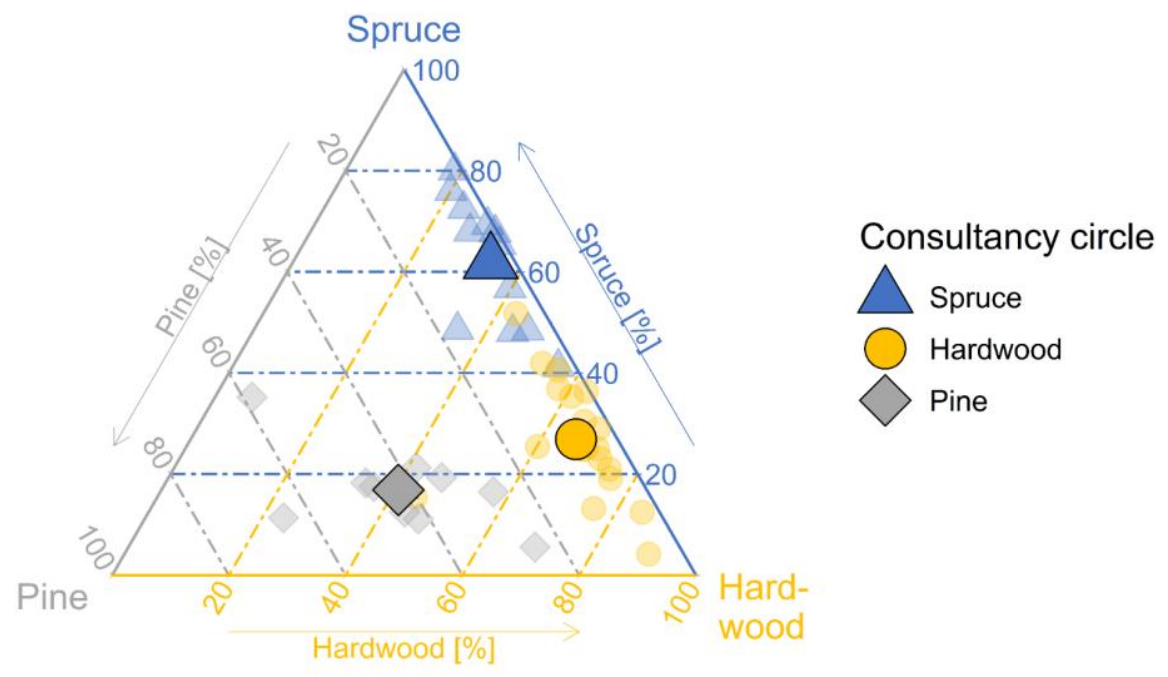

Fig. 1. Allocation of tree species groups in the forest enterprises of the FAN Westfalen-Lippe. The small points illustrate the mean percent values of the tree species group composition in the individual forest enterprises from 1985 to 2015 . The large points represent the mean values of the consultancy circles.

Fig. 1 can be interpreted as follows: The small points show the individual forest enterprises, which proportionally comprise all three tree species groups. Note that the tree species groups beech and oak have been summarized under hardwoods. The closer a forest enterprise is located to one of the corners of the triangle-diagram, the more dominating that tree species group is in the enterprise compared to the other tree species groups. A forest enterprise is more evenly diversified when it is located towards the center of the triangle-diagram, which indicates that all three tree species groups are equally represented. Fig. 1 shows, that only a few enterprises show a particularly high dominance of one of the tree species groups (see corners of the triangle in Fig. 1). This is the case for some spruce enterprises as well as hardwood enterprises. The pine enterprises contain a relatively high portion of hardwood species but show a lack of spruce species. In summary, looking at the mean values of the consultancy circles, the spruce enterprises on average are made up of roughly $35 \%$ hardwood species and the hardwood enterprises have a portion of approximately $30 \%$ spruce species. The pine 
Analysis of empirical tree species diversification effects with the use of forest accountancy data network data

enterprises show the highest even diversity of tree species groups with a large portion of hardwood species and just $20 \%$ spruce. In the original publication, this indicated diversity of tree species in the forest enterprises was confirmed by calculating the standardized diversity Shannon-index (evenness) (see Pretzsch, 2009, p. 279ff.; Shannon \& Weaver, 1948) as a measure for biodiversity.

The studies objective was to analyze the empirical effects of tree species diversity in forest enterprises by applying the data of the FAN Westfalen-Lippe to the concept of the diversification effect, which is a term specifically described in e.g. Gibson (1990), Perold (2004), and Hight (2010) for financial assets. The diversification effect, which, in our specific case, describes the relationship between net timber income correlations and forest enterprise portfolio risks (cf. Hight, 2010) is a fundamental component of Markowitz' (1952) modern portfolio theory. The idea of the diversification effect has long been transferred to biodiversity (see Figge, 2004) and particularly the economics of tree species (see e.g. Knoke et al., 2008).

Besides measuring the diversification effect in forest enterprises, the study focused on the applicability of empirical forest enterprise data to the theoretical concept and discusses specific implications for forestry.

\subsubsection{Methodology and main results}

The economic analysis was based on the performance of the forest enterprises during the years 1985-2015. The relevant data used were the revenues and costs directly connected to timber production (timber harvest). Subtracting the immediate timber harvesting costs from the revenues yields the contribution margin I (CM I) (see Speidel, 1967, p. 76ff.). The CM I is the net revenue from timber harvest, which was calculated for each forest enterprises as a whole and for the individual tree species groups separately. The time series data in Fig. 2 shows the development of the mean CM I per hectare $\left(€\right.$ ha-1 $\left.^{-1}\right)$ of the consultancy circles over time.

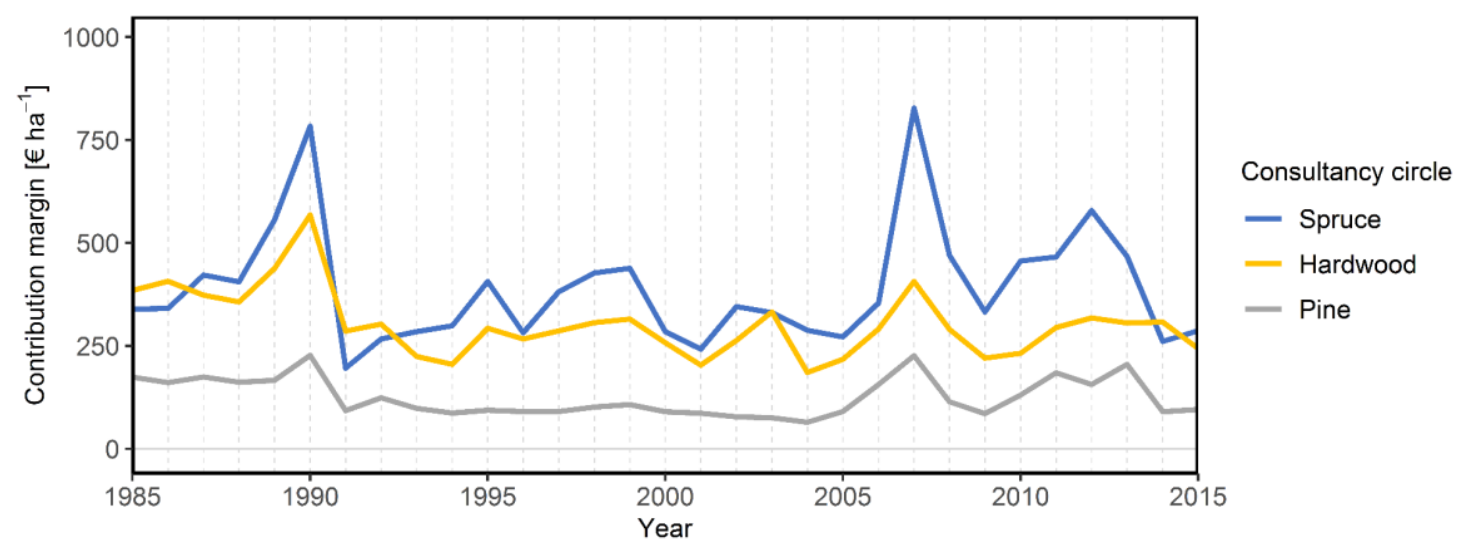

Fig. 2 Development of the mean annual contribution margins of the forest enterprises grouped by consultancy circles. (Figure adapted from Wildberg \& Möhring, 2019, colorized) 
Analysis of empirical tree species diversification effects with the use of forest accountancy data network data

This allows to calculate the mean height and standard deviation of the CM I for all enterprises and consultancy circles as a measure of risk (see Knoke, 2012, p. 81). By graphically plotting the standard deviation against the mean return indicates a correlation between the height of the contribution margin and its volatility. Fig. 3 shows a mean variance diagram typically used for individual asset. A similar figure can be found in Möhring (2004).

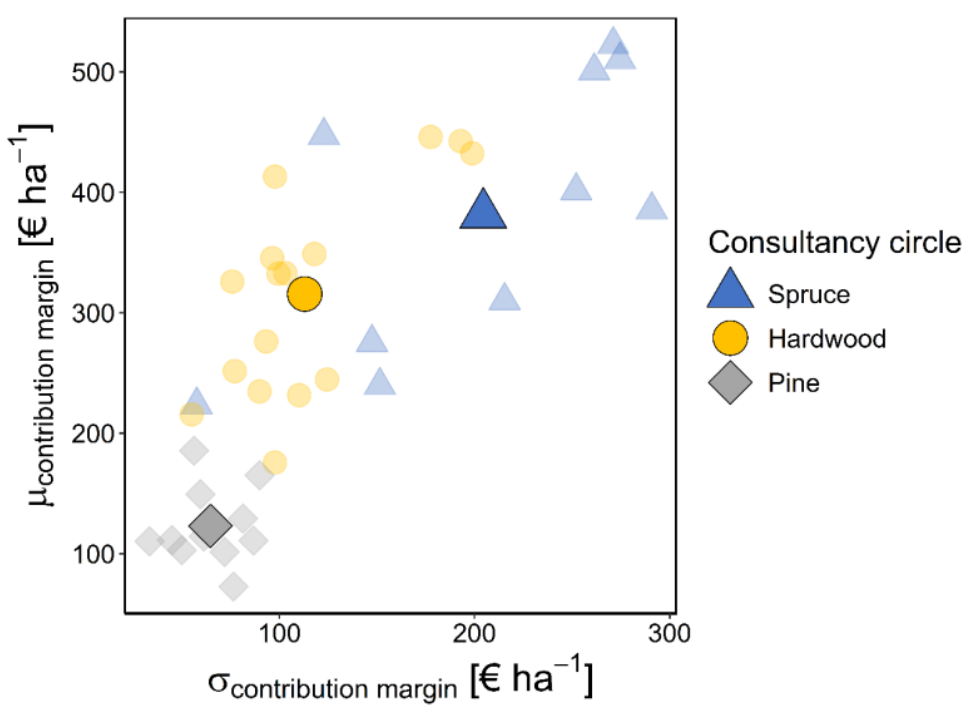

Fig. 3. Mean vs. standard deviation of the annual contribution margins of the forest enterprises grouped by consultancy circles. The small points illustrate the individual forest enterprises while the large points show the mean values of each consultancy circle. (Figure from Wildberg \& Möhring, 2019, colorized. A similar figure can be found in Möhring, 2004)

Fig. 3 shows the spruce enterprises had the highest mean CM I and the highest volatility over time. The spruce enterprises are followed by the hardwood enterprises in terms of CM I height and volatility. The CM I of the pine enterprises were least volatile over time but also showed lower mean levels.

The mean and volatility of the CM I of the forest enterprises is the result of the CM I of the individual underlying tree species groups. Fig. 4 shows the development of the CM I of the tree species groups over time. 
Analysis of empirical tree species diversification effects with the use of forest accountancy data network data

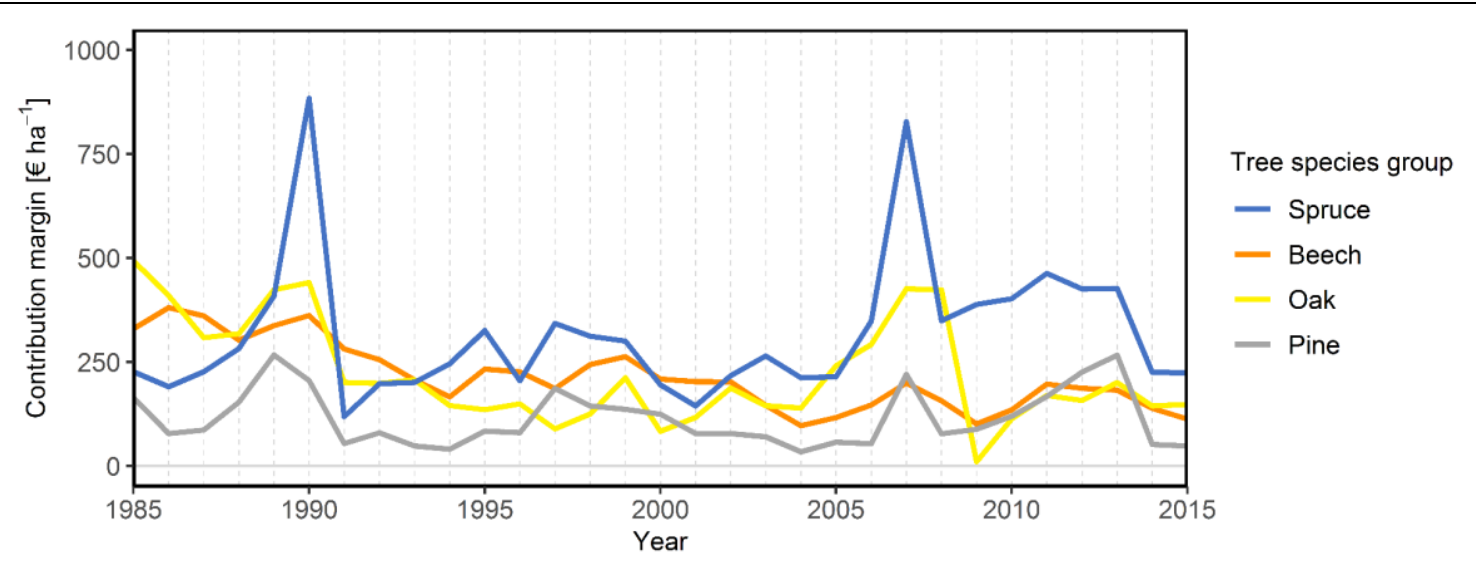

Fig. 4 Development of the mean annual contribution margins of the tree species groups. (Figure adapted from Wildberg \& Möhring, 2019, colorized)

For a better understanding, the same diagram as Fig. 3 for the forest enterprises can be made for the individual tree species groups within these enterprises. This illustrates how the individual tree species group contributed to the development of the CM I of the forest enterprises.

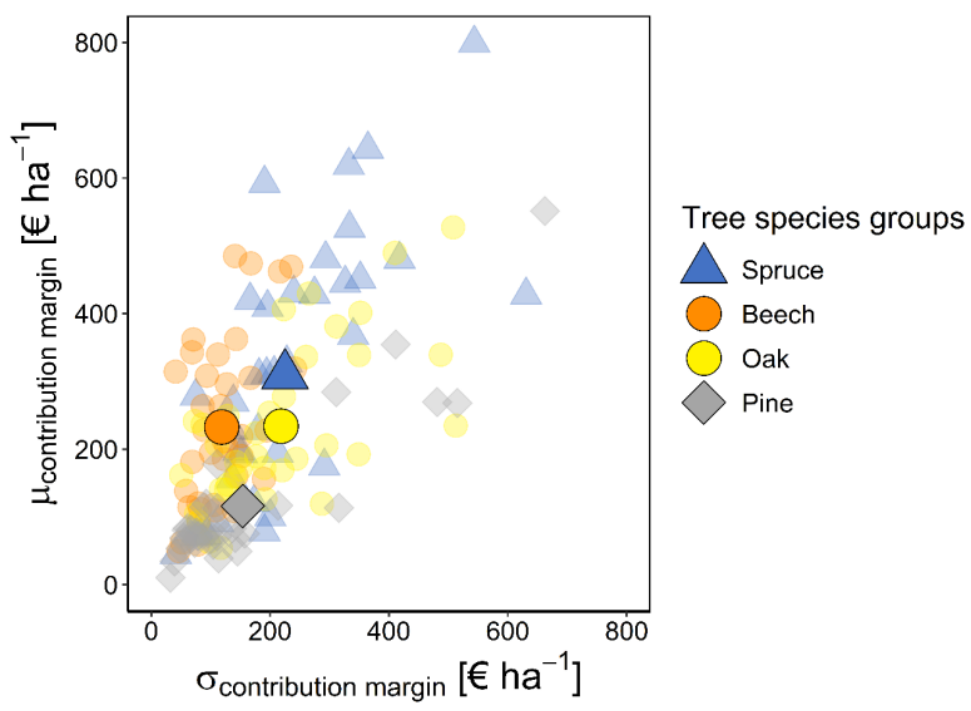

Fig. 5. Mean vs. standard deviation of the annual contribution margins per tree species area of the tree species groups in the forest enterprises. The small points illustrate the individual tree species groups while the large points represent the mean values for each tree species group. (Figure from Wildberg \& Möhring, 2019, colorized)

Fig. 5 shows the spruce species provided the highest CM I per tree species area followed by the hardwood species and the pine. Again, there is a clear indicated correlation between the height 
Analysis of empirical tree species diversification effects with the use of forest accountancy data network data

of the CM I and the standard deviation. It can be inferred for example that the volatility of the CM I in the forest enterprises was mainly caused by the volatility of CM I of the spruce species.

The diversification effect can be explained by connecting the tree species level (as of Fig. 5) to the forest enterprise level (as of Fig. 3): The mean contribution margins of the four individual tree species groups combine linearly (see Perold, 2004) within in a forest enterprise. This means, the sum of the weighted $(\omega)$ mean $(\mu)$ CMs I of the individual tree species groups $(a-d)$ is equal to the mean CM I of the forest enterprise portfolio (see equation 1, which was adapted from Markowitz, 1952).

$\mu_{p}=\omega_{a} \mu_{a}+\omega_{b} \mu_{b}+\omega_{c} \mu_{c}+\omega_{d} \mu_{d}$

The standard deviation of the contribution margin in the forest enterprises $\left(\sigma_{p}\right)$ however, will be lower than the sum of the weighted standard deviation of the CM I of the individual tree species $\left(\sigma_{i}\right)$ given they are not perfectly positively correlated (see equation 2 , which was adapted from Hight, 2010 and is based on the works of Markowitz, 1952 on portfolio risk).

$\sigma_{p}=\sqrt{\begin{array}{l}\omega_{a}^{2} \sigma_{a}^{2}+\omega_{b}^{2} \sigma_{b}^{2}+\omega_{c}^{2} \sigma_{c}^{2}+\omega_{d}^{2} \sigma_{d}^{2}+2 \omega_{a} \omega_{b} \sigma_{a} \sigma_{b} \rho_{a b}+2 \omega_{a} \omega_{c} \sigma_{a} \sigma_{c} \rho_{a c}+ \\ 2 \omega_{a} \omega_{d} \sigma_{a} \sigma_{d} \rho_{a d}+2 \omega_{b} \omega_{c} \sigma_{b} \sigma_{c} \rho_{b c}+2 \omega_{b} \omega_{d} \sigma_{b} \sigma_{d} \rho_{b d}+2 \omega_{c} \omega_{d} \sigma_{c} \sigma_{d} \rho_{c d}\end{array}}$

Hence, the diversification effect is dependent on the correlation between assets (Perold, 2004 on the findings of Markowitz, 1952). In equation 2, the correlation coefficients between the tree species group pairs are expressed as $\rho_{a b}$ for spruce and beech, $\rho_{a c}$ for spruce and oak, $\rho_{a d}$ for spruce and pine, $\rho_{b c}$ for beech and oak, $\rho_{b d}$ for beech and pine and lastly $\rho_{c d}$ for oak and pine. No diversification effect occurs when the (tree species) assets are perfectly positively correlated ( $\rho=1$, meaning they move in the same direction proportionally) (Perold, 2004). As soon as the (tree species) assets are not perfectly positively correlated $(\rho<1)$, the standard deviation of one (tree species) asset will balance out the standard deviation of another (tree species) asset in the (forest enterprise) portfolio (see Perold, 2004).

What is described in equation 1 and 2 was empirically illustrated for the forest enterprise portfolios in Fig. 6. 
Analysis of empirical tree species diversification effects with the use of forest accountancy data network data

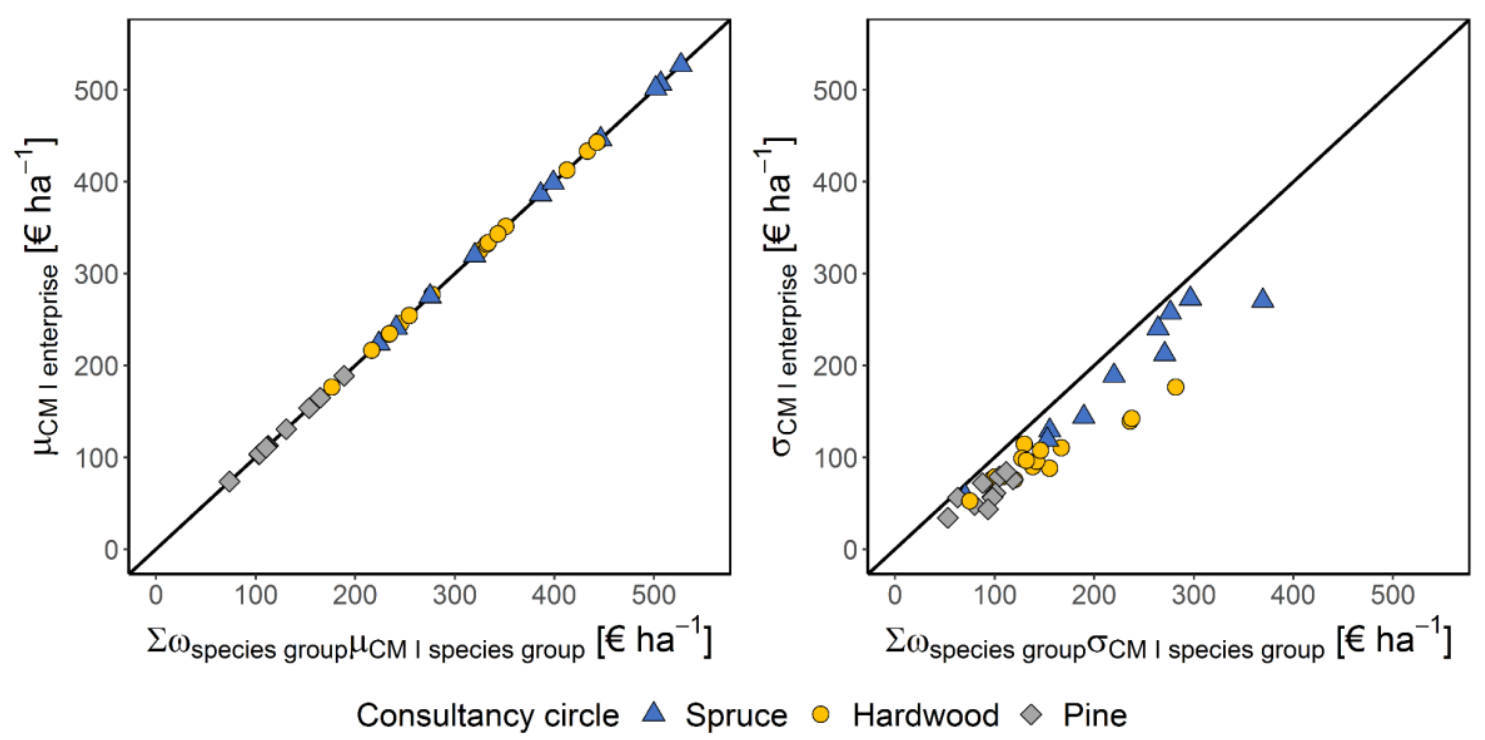

Fig. 6. Linear combination of return vs. nonlinear combination of risk. Comparison of the mean CM I of the forest enterprises ( $\mu \mathrm{CM}$ I enterprise) to the sum of weighted mean CMs I of the tree species groups ( $\Sigma \omega$ species group $\mu \mathrm{CM}$ Ispecies group) (left) and the standard deviation of the CMs I of the forest enterprises ( $\sigma \mathrm{CM}$ I enterprise) to the sum of the weighted standard deviation of the CMs I of the tree species groups ( $\Sigma \omega$ species groupoCM I species group) (right). (Figure from Wildberg \& Möhring, 2019, colorized)

The left side of Fig. 6 shows, that the mean CM I of the forest enterprises is equal to the sum of the weighted mean CM I of the underlying tree species groups as of equation 1 . The right side shows that the standard deviation of the CM I of the forest enterprises is lower than the standard deviation of the CM I of the weighted underlying tree species groups.

As Fig. 6 illustrates a diversification effect in each of the forest enterprises, there is barely a precise indication on the amount of volatility reduction that occurred within the forest enterprises as a measure of the diversification effect. Based on the works of Cheng and Roulac (2007) and Choueifaty and Coignard (2008) the magnitude of the diversification effect can be calculated using a ratio between the volatility of the portfolio and the volatility of the weighted individual assets. The following equation has been adapted from Hight (2009) and Hight (2010) for the four asset forest enterprise portfolio and is fundamentally based on the ideas as seen in Cheng and Roulac (2007) and Choueifaty and Coignard (2008).

$1-\left(\frac{\sigma_{p}}{\omega_{a} \sigma_{a}+\omega_{b} \sigma_{b}+\omega_{c} \sigma_{c}+\omega_{d} \sigma_{d}}\right)$

The equation calculates the amount of volatility reduction within the enterprise portfolio expressed in a value between 0 (no effect) and 1 (Hight, 2010). Calculations of the ratios in the forest enterprises showed that the highest risk reduction or diversification effects occurred in the pine 
Analysis of empirical tree species diversification effects with the use of forest accountancy data network data

enterprises with the highest standardized species diversity. On average, the spruce enterprises showed the lowest diversification effects.

The magnitude of the diversification effect is dependent on the correlation of the contribution margins of the tree species groups, which can be explained by opposing fluctuations in timber prices and harvested amounts of timber. However, when taking a closer look back at the time series data of the individual tree species groups, it could be seen that the contribution margins showed up and down trends over time (see Fig. 7).
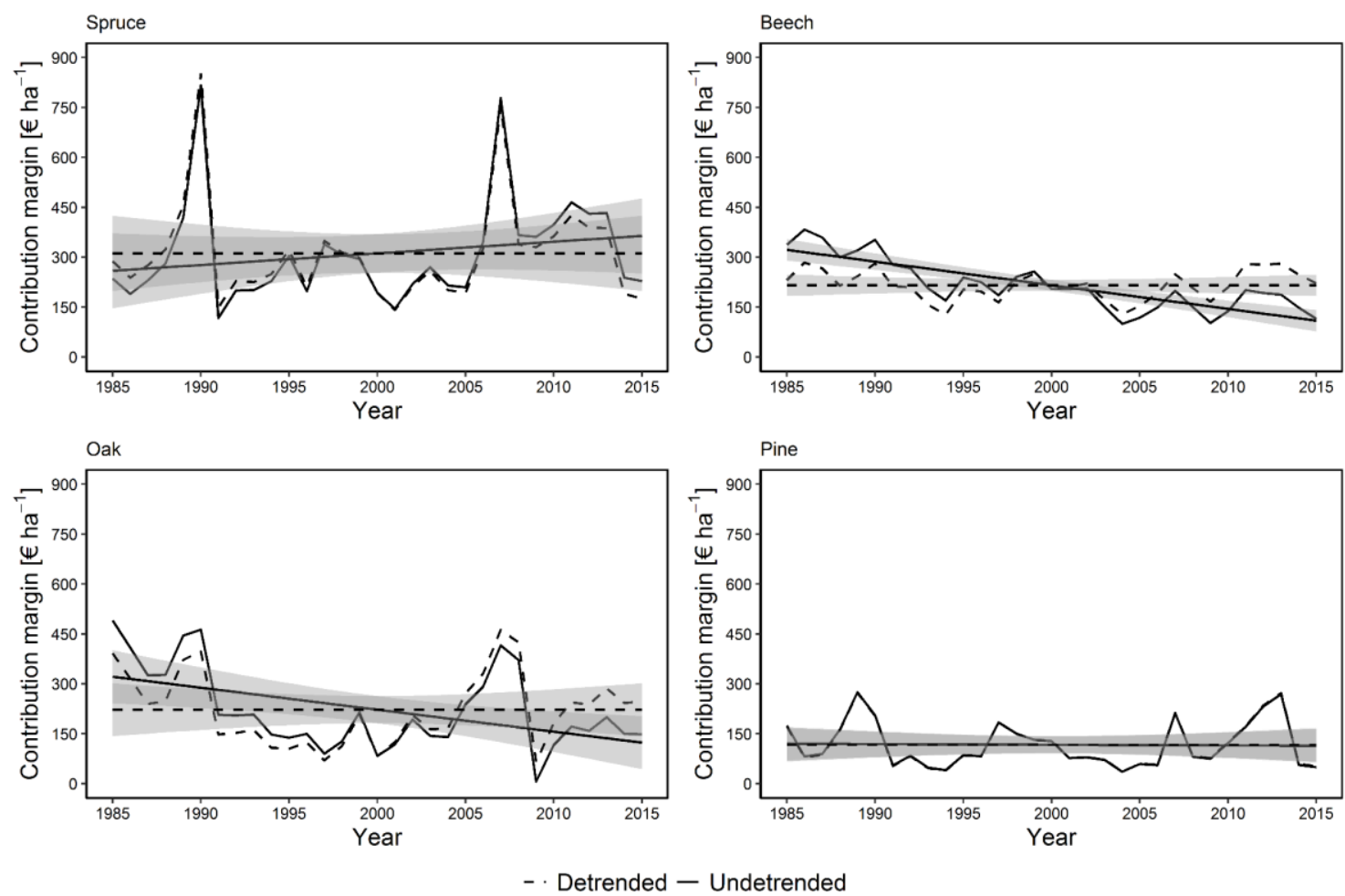

Fig. 7 Undetrended and detrended mean development of the annual contribution margins of the tree species groups of the forest enterprises. (Figure from Wildberg \& Möhring, 2019)

The calculation of the correlation coefficients showed that none of the tree species were negatively correlated but the spruce and the beech species showed the weakest positive correlation $(\rho=0.07)$. After detrending the time series data, the correlations between the tree species groups were generally more positive. In fact, the correlation coefficient of spruce and beech went up from 0.07 to 0.42 . Expectedly, the diversification effects in the forest enterprises were lower after detrending the data. This highlights how trends can be responsible for a large portion of the diversification effect when applied to empirical data. From another perspective, trends are not considered in the diversification effect as the theory assumes that the data is stationary. Part of the diversification effect is due to trends moving in opposite directions. 


\section{$3 \quad$ Financing, liquidity and sustainability in forest enterprises}

The second topic comprise the studies 3 and 4, which highlight the topics of financing and liquidity from two different perspectives of sustainable forest enterprise management. Study 3 (section 3.1) focusses on the liquidity problem of forest enterprises as a result of the recent calamity events within an empirical field study. Study 4 (section 3.2) analyzes the influence of capital market assumptions on the optimal rotation age and harvesting pattern.

\subsection{Study 3: Liquiditätssicherung privater Forstbetriebe bei Kalamität \\ Measures safeguarding liquidity of private forest enterprises in times of calamity}

\subsubsection{Background and context}

Extreme weather conditions during the years 2018 until 2020 have caused severe damages to forest lands in Germany (Möhring et al., 2021). The damage accumulates to an approximate total of up to 176.8M. solid cubic meters (EUWID, 2020; Möhring et al., 2021) of salvage timber. The amounts of timber lead to a flooding of the timber markets (Lehmann, 2020) and subsequently a drop in prices (Möhring et al., 2021). Furthermore, timber assets were destroyed by the following drought and bark beetle infestation (Möhring et al., 2021). Sufficient funding from timber sales could no longer be provided, which threatens the livelihood of forest enterprises and requires to develop new strategies and tools for regular income (Arnim, 2020).

The aim of this study was to get an overview of the current situation and analyze the topic of financing in private forest enterprises in times of calamity. In this context the applicability of the taxfree reserve of $\S 3$ the Forest Damage Compensation Act and other potential future tools and measures to support forest enterprises were investigated.

\subsubsection{Methodology and main results}

In cooperation with the Waldbauernverbrand Nordrhein-Westfalen and the consulting firm BB Göttingen $\mathrm{GmbH}$ a total of approximately 400 private forest enterprises were asked to answer a series of closed and open questions concerning their operational orientation and objectives, calamity impact during the years 2018 to 2019 and possible measures to increase profits including new alternatives to timber production. After receiving the results of approximately 300 questioners, the forest enterprises were divided into groups depending on their dominating tree species similar to the forest enterprises of the FAN Westfalen-Lippe (see section 2) for a better comparability. Furthermore, the enterprises were separated into groups of large ( $\geq 500 \mathrm{ha}$ ), medium ( $50-500 \mathrm{ha}$ ) and small ( $\leq 50 \mathrm{ha}$ ) forest enterprises to detect differences that can be associated to enterprise size.

Regarding the objectives, the forest enterprises were asked to express their priorities towards different operational objectives. Tab. 2 shows the average importance towards objectives in descending order (over all forest enterprises). There was however a clear indicated correlation between certain preferred operational objectives and forest enterprise size. 
Tab. 2 List of operational objectives of the forest enterprises arranged in descending order of priority (over all enterprises). The numbers indicate the level of importance of the objectives with values from 1 (most important) to 4 (least important). (Keywords translated from Arnim et al., 2020)

\begin{tabular}{lcccc}
\hline & \multicolumn{5}{c}{ Enterprise size } \\
& Total & Small & Medium & Large \\
\hline Maintaining asset value & 1.3 & 1.5 & 1.2 & 1.2 \\
Profitability and income & 1.6 & 2.1 & 1.4 & 1.4 \\
Tradition & 1.9 & 1.9 & 1.9 & 1.9 \\
Safeguarding liquidity & 1.9 & 2.6 & 1.7 & 1.8 \\
Nature and environmental protection & 2.0 & 1.7 & 2.0 & 2.4 \\
Rural social responsibility & 2.1 & 1.9 & 2.1 & 2.3 \\
Esthetics and landscaping & 2.2 & 1.9 & 2.2 & 2.4 \\
Hunting & 2.8 & 3.5 & 2.5 & 2.7 \\
Firewood for self-consumption & 2.8 & 2.1 & 2.4 & 3.0 \\
\hline
\end{tabular}

Especially the large and middle-sized enterprises expressed a stronger economic focus in their operational goals. The smaller enterprises were more concerned with ecological and social objectives.

Regarding calamity exposure in the years 2018 and 2019, the small forest enterprises were strongly impacted by timber salvage, followed by the middle-sized enterprises and the large enterprises. On average, calamity induced timber harvests made up $77 \%$ in 2018 and $86 \%$ in 2019 of the total timber harvests.

Regarding the tax-free reserve, the results showed that only a minority of the forest enterprises own a tax-free reserve with an average of $80 €$ ha- $^{-1}$. While about half of the enterprises did not resort to the tax-free reserve during the respective years, the other half liquidated the reserves mainly to finance afforestation. The forest enterprises were asked to state reason for not owning a tax-free reserve. The main reasons were the complexity and bureaucracy that made it difficult to own a tax-free reserve. In addition, some enterprises stated that they do not meet the requirements to establish a tax-free reserve or did not generate sufficient income in the past. Furthermore, investing in a tax-free is not considered very profitable for the forest enterprise. To improve the practicability of the tax-free reserve, the forest enterprises suggest less bureaucracy, expanding the maximum amount of the reserve and the reasons for liquidating the reserve need to be expanded.

In order to determine measures for safeguarding liquidity in forest enterprises after a calamity event the forest enterprises were asked to rank the applicability of possible measures to save costs and increasing revenue. In addition, the forest enterprises were asked to list policy instruments that could provide financial support after calamities (see Tab. 3). 
Tab. 3 List of possible measures to avoid expenses, increase revenue and forest policy instruments in descending order of priority (over all enterprises). (Keywords translated from Arnim et al., 2020)

\begin{tabular}{lll}
\hline Measure to... & & Forest policy instruments \\
\hline ...save expenses & ...increase revenue & $\mathrm{CO}_{2}$ reward \\
\hline $\begin{array}{l}\text { In private withdrawals } \\
\text { In nature conservation, }\end{array}$ & Expand business portfolio & Reducing public expenses \\
\hline In labor and administration costs & Claim grants/funding & $\begin{array}{l}\text { Honor processing of salvage } \\
\text { timber }\end{array}$ \\
\hline In forest infrastructure & Reduce standing timber & $\begin{array}{l}\text { Pause timber harvest in state } \\
\text { enterprises }\end{array}$ \\
\hline In forest rejuvenation & Liquidate reserves & Provisioning infrastructure \\
\hline In hunting & Hunting lease & $\begin{array}{l}\text { State funded forest damage } \\
\text { insurance }\end{array}$ \\
\hline In forest protection & Short term credit & State support \\
\hline In forest stand tending & Long-term credit & Crowd funding for reforestation \\
\hline $\begin{array}{l}\text { In timber production and } \\
\text { byproducts }\end{array}$ & Sell forest land & Subsidy on loans \\
\hline
\end{tabular}

The list of measures showed that reducing the withdrawal of private expenses play a major role in securing liquidity. Small forest enterprises see potential for saving costs in forest protection and rejuvenation. Large forest enterprises want to reduce costs in nature conservation and recreation as well as hunting. The results also show that forest enterprises want to increase revenues by expanding or developing new fields and expand towards ancillary use and profit from grants and subsidies. All forest enterprises show that they want to prevent the lease of their own hunting grounds, take external funding for financing and sell forest land. Regarding policy instruments, all enterprises see potential in honoring $\mathrm{CO}_{2}$ and other ecosystem serves as well as a reduction of taxes and fees. 


\subsection{Study 4: Continuous timber harvest - Costly restriction or profitable solution?}

\subsubsection{Background and context}

The previous study 3 in section 3.1 emphasizes the importance of self-financing for forest enterprises. Even in the case of income gaps from intermittent timber production, forest enterprises will try to avoid external funding in the short and long term. This stands in a certain contrast to the common assumption of a perfect capital market with an unlimited availability of capital that can be borrowed and lent at constant interest rates in well-established investment calculations in forest economics.

The Faustmann-Pressler-Ohlin rule (FPO-rule) (Johansson \& Löfgren, 1985, p. 80) for determining the optimal forest stand rotation period is a prominent example of an investment calculation that is based on the assumption of a perfect capital market (see e.g. Möhring \& Dieter, 2020; Tahvonen et al., 2001). A forest stand reaches the optimal age of maturity when its current value increment is equal to the cost of capital, which comprises the land and stand holding costs (see Borchert, 2002, p. 13; Möhring \& Dieter, 2020). The cost of capital is determined by an interest rate, which serves as a guiding price for the investor (see Hering, 2017, p. 4) to maximize wealth (net present value, NPV) and income (annuity) simultaneously (see Kruschwitz \& Lorenz, 2019, p. 68, 73) from timber production. Deviations from the optimal age of maturity to secure a specific regularity of timber production involve a loss in profitability (see Mitra \& Wan, 1985) as they result in inefficient investment or financing costs (see Möhring \& Dieter, 2020).

This stands in a certain contradiction to the traditional demand for even flow of income as part of sustainable forest management (Speidel, 1972, p. 54). The objective of this study is therefore to analyze the influence of the common perfect capital market assumption on the profitability of irregular timber income associated with following the FPO-rule. Reversely, by giving up the assumption of a perfect capital market and introducing differing borrowing and lending rates the profitability of continuous and regular timber income should be illustrated. In this way, it is to be examined whether the change in the capital market assumption can economically explain the common preference of forest enterprises for sustainability in the sense of a steady flow of income.

The analysis is based on a spruce (Picea abies) forest stand production model. The fundamental model can also be found in the works of e.g. Möhring and Dieter (2020) and Möhring (2010) and is used for teaching at the University of Göttingen (Möhring \& Mitarbeiter, 2019, p. 136ff.). The model is based on non-linear functions for growth and volume by Smaltschinski (2001), which are based on yield tables of Wiedemann (1936/42) published in Schober (1995). Volume dependent revenue and cost values are based on the works of Spellmann (2017) and Bodelschwingh (2018). The model included fixed and variable costs identical to Möhring and Dieter (2020). 
a

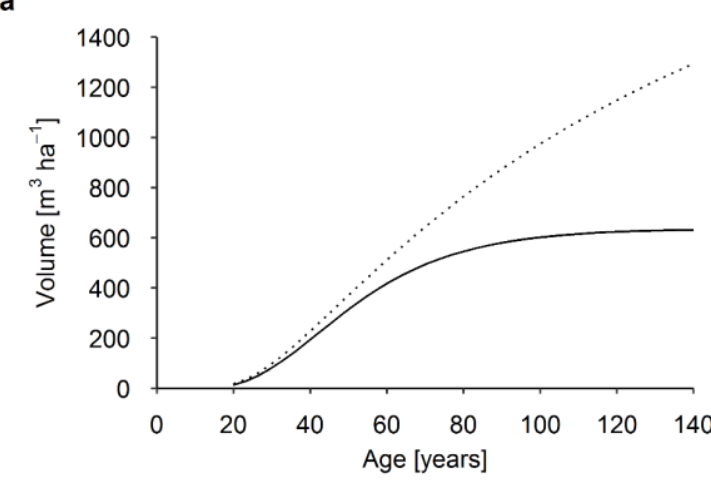

.... Total volume yield - Normal standing volume

C

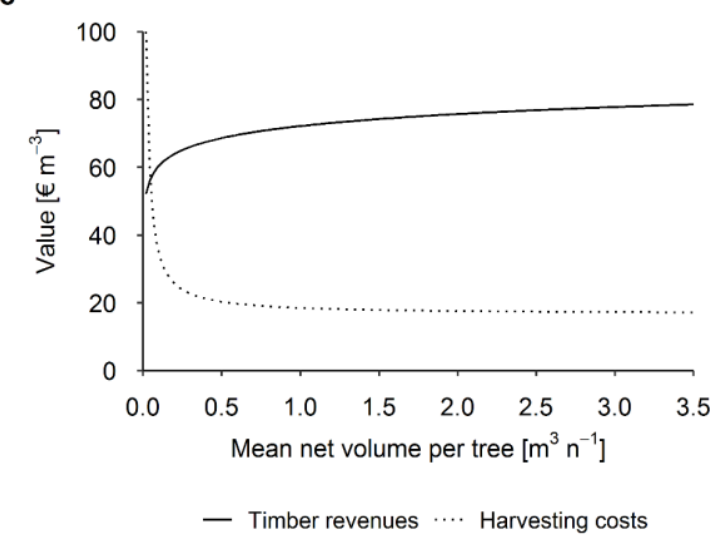

b -

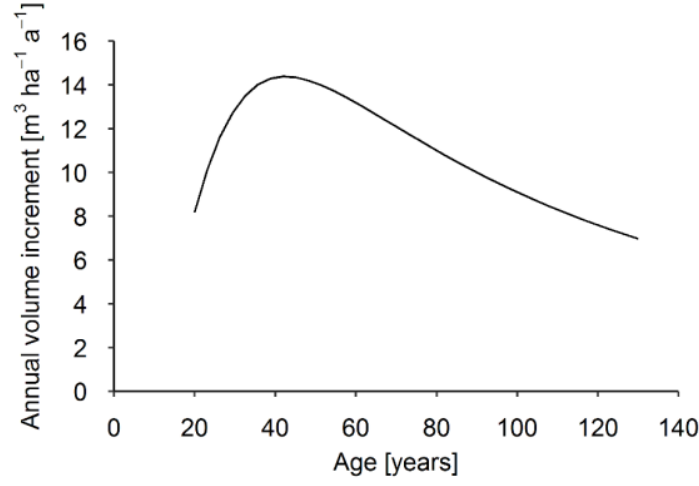

Fig. 8 Underlying natural (a-b) and economic (c) functions of the forest stand production model. (Figure from Wildberg \& Möhring, 2021 and adapted from Möhring, 2010; Möhring \& Dieter, 2020; Möhring \& Mitarbeiter, 2019, p. 137)

Based on the functions of Fig. 8 a spruce forest stand development was set up/simulated in a spreadsheet with natural and economic development forming a cash flow dependent on the forest management strategy. The cash flow serves as a basis for evaluating the forest management strategy which allows to determine the net soil rent (see e.g. Möhring et al., 2006; Möhring \& Dieter, 2020) and the land expectation value (LEV) (see Faustmann, 1849; Klemperer, 1996, p. 204ff.; Möhring \& Dieter, 2020).

\subsubsection{Analysis and main results}

By means of a variation study the model allows to determine the net soil rent for varying rotation ages and interest rates. Fig. 9 shows the net soil rent at $0 \%, 1 \%$, and $2 \%$ interest rate and for varying rotation ages at 10 -year discrete periods. 


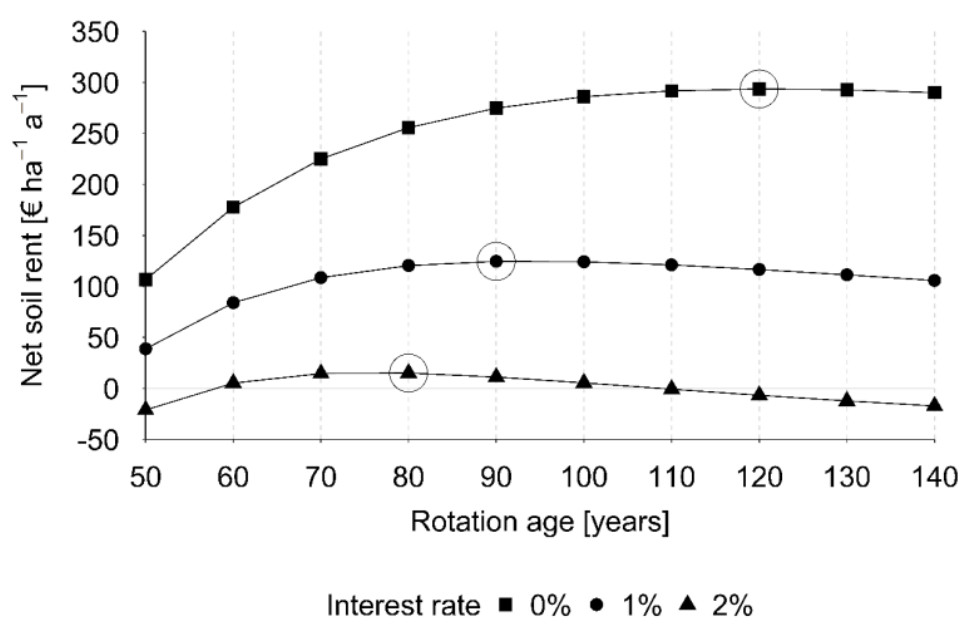

Fig. 9. Net soil rent for varying forest stand rotation ages and interest rates. The maximum net soil rent for each interest rate is marked with a circle revealing the optimal forest stand rotation age. (Figure from Wildberg \& Möhring, 2021)

Fig. 9 shows, that the net soil rent decreases with increasing interest rates and reveals the optimal rotation age for each interest rate at the point of maximum net soil rent. For the following simulation and analysis an interest rate of $1 \%$ was applied.

On the basis of the single stand model a normal forest enterprise of 100 ha in size and eight 10 -year age classes (12.5 ha per age class) with an intentionally non-optimal rotation age of 80 years at an interest rate of $1 \%$ was simulated. At an interest rate of $1 \%$ the oldest age class of the normal forest had not reached its optimal age (see Fig. 9). This was done to create a scenario that allowed to analyze different strategies to reach the optimal harvesting age. The normal forest enterprise produced a constant net timber income of $255.62 €$ ha $^{-1} \mathrm{a}^{-1}$, which is equal to the net soil rent of the 80-year forest stand management strategy at 0\% (see also Möhring, 2001 and Möhring, 1994, p. 74f.)

In order to reach the optimal rotation age of 90 years, two alternative forest transitions were simulated: 1) A periodic transition where the final harvest is paused for 10 years until the 80 -year old timber reaches 90 years. 2) A continuous transition where the final harvest is reduced so that a small yet increasing portion of the oldest age class continuously grows into the 81-90-year age class. Fig. 10 illustrates the development of the net timber income resulting from the two forest enterprise transitions. 

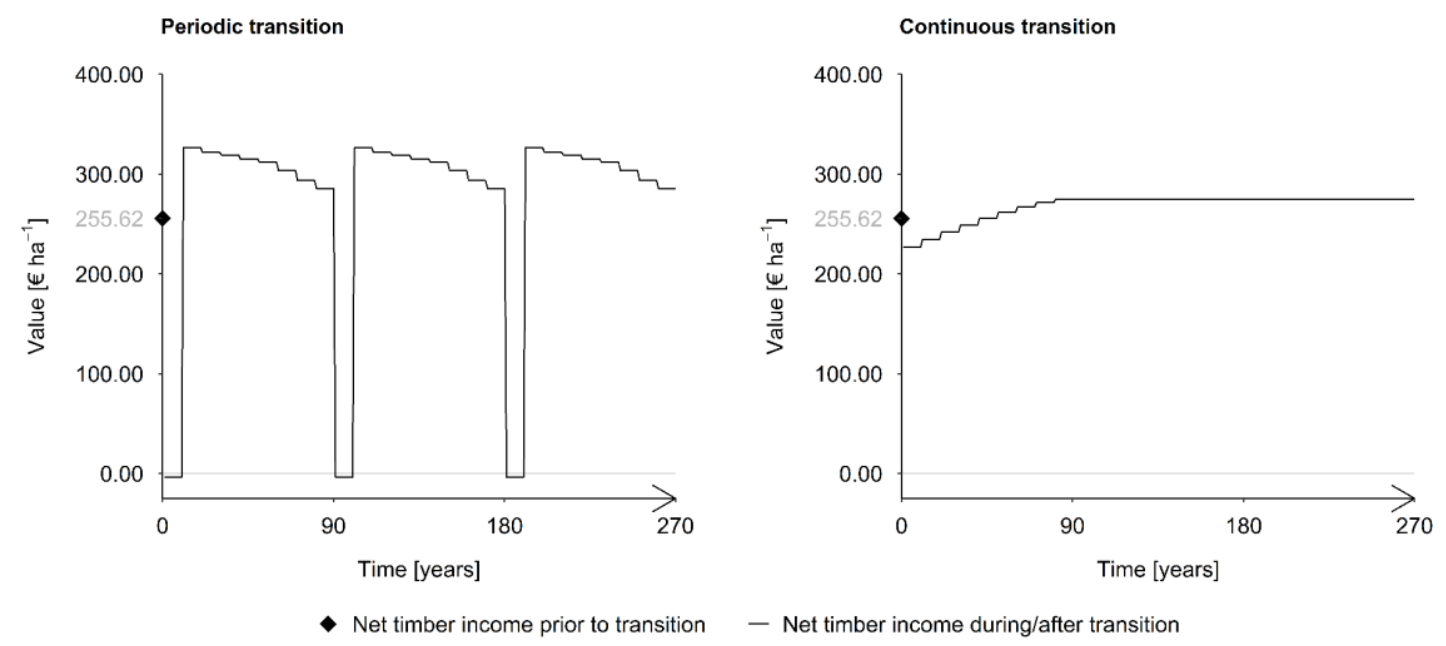

Fig. 10. Development of the net timber income resulting from the periodic transition (left) and the continuous transition (right). (Figure from Wildberg \& Möhring, 2021)

While the periodic transition resulted in a permanent loss of the normal forest structure, the continuous transition resulted in a temporary loss of the normal forest stand structure and finally a new normal forest structure with a higher rotation age.

To determine the profitability of the forest enterprise transitions the NPV and annuity of the net timber income were calculated for an infinite time horizon. Tab. 4 compares the NPV and annuity of the two transitions to the NPV/annuity of the initial normal forest enterprise.

Tab. 4. Net present value and annuity of the net timber income resulting from the periodic and continuous forest enterprise transitions. The results are compared to the NPV and annuity of the net timber income of the initial normal forest enterprise. (Table from Wildberg \& Möhring, 2021)

\begin{tabular}{lllll}
\hline Interest rate 1\% & Initial state & $\begin{array}{l}\text { Periodic } \\
\text { transition }\end{array}$ & $\begin{array}{l}\text { Continuous } \\
\text { transition }\end{array}$ \\
\hline Rotation age & years & 80 & 90 & 90 \\
NPV of net timber income & $€$ ha $^{-1}$ & 25,562 & 26,187 & 25,996 \\
Annuity of net timber income & $€$ ha $^{-1} \mathrm{a}^{-1}$ & 255.62 & 261.87 & 259.96 \\
\hline
\end{tabular}

As seen in Tab. 4 both transitions increased the profitability compared to the initial state. The annuity of the initial forest enterprise is equal to its steady net timber income (i.e. the output the forest enterprise produces). This means the annuity (resp. the net timber income) of the initial normal forest enterprise can be interpreted as the maximum amount possible but also the minimum amount required to be withdrawn from the forest enterprise in order to maintain a steady state.

Likewise, the annuities of the forest enterprise transitions can be interpreted as the maximum annual constant value that can be withdrawn during/after the forest enterprise transitions. This becomes apparent, when the forest enterprise model is explicitly expanded by an 
external source for funding the forest enterprise transition as it is implied in the perfect capital market.

By considering an external source for financing and investing illustrates the investive character of the forest enterprise transitions. Measure of profitability is defined as the maximum annual payout (MAP) of the forest enterprise and financial investment combination. The MAP is the amount that can be withdrawn in perpetuity from the investment combination, meaning the combination needs to achieve a perpetual equilibrium state (see Fig. 7).

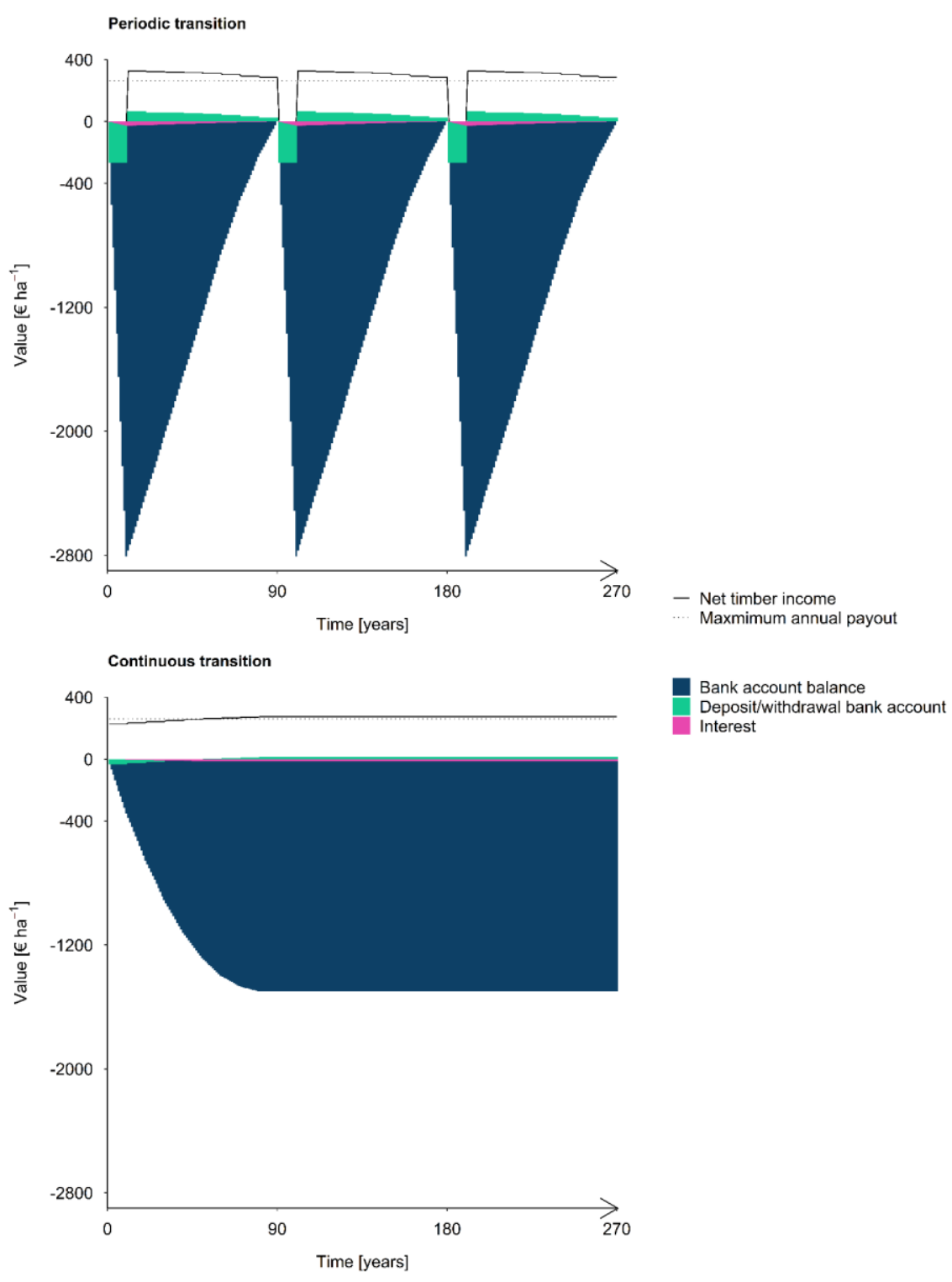

Fig. 11. Combination of forest enterprise and financial investment. Annual development of the net timber income and the bank account when the maximum annual payout is taken out from the combination of forest enterprise and financial investment. (Figure from Wildberg \& Möhring, 2021, colorized) 
It becomes apparent that the MAP of the forest enterprise and external source combination is equal to the annuity of the net timber income of the transitions in Tab. 4 (see also Kruschwitz \& Lorenz, 2019, p. 60ff.)

In order to analyze the forest enterprise transitions under varying borrowing and lending rates, an interest rate function was applied so that borrowing and lending rates differ as a function of capital availability (see Fig. 12).

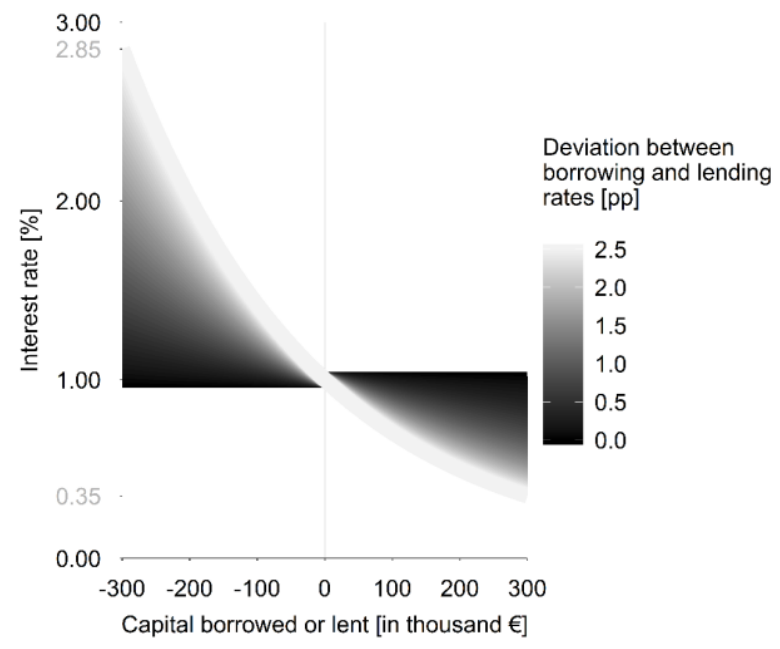

Fig. 12. Interest rate curve for varying intensities of capital market imperfection. Illustration of the interest rate function showing a constant interest rate of $1 \%$ within the perfect capital market and varying intensities of capital-volume dependent interest rate within the imperfect capital market. (Figure from Wildberg \& Möhring, 2021)

Using a variation study, the maximum annual payout, was calculated for an increasing deviation between the borrowing and lending rates (see Fig. 13). 


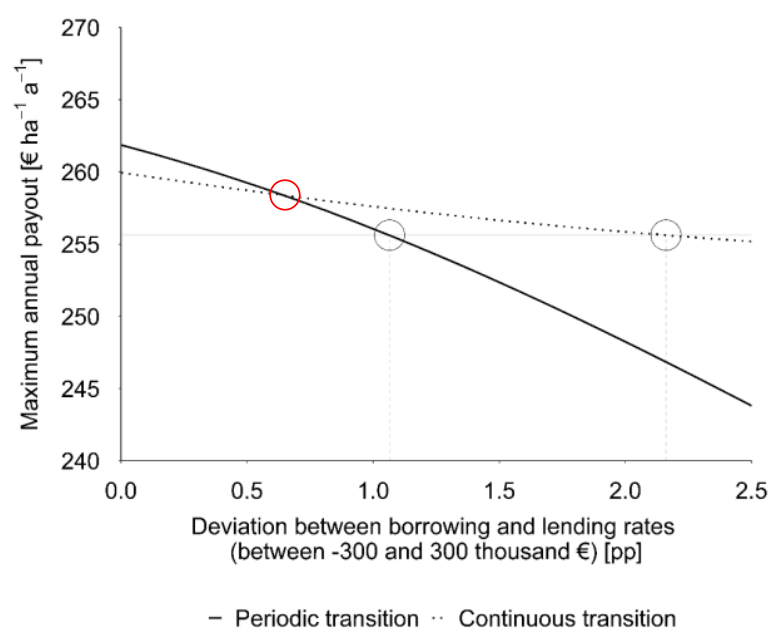

Fig. 13. Relative profitability, expressed by the maximum annual payout, of the periodic vs. the continuous forest enterprise transition for varying intensities of capital market imperfection. The deviation between borrowing and lending rates between -300 and 300 thousand $€$ indicates the degree of capital market imperfection starting from $0.00 \mathrm{pp}$ deviation (perfect capital market). The horizontal gray line indicates the initial maximum annual payout of $255.62 € \mathrm{ha}^{-1} \mathrm{a}^{-1}$ prior to transition. The red circle indicates the switch in relative profitability of the two transition alternatives. The black circles indicate the point until the transition no longer increases profitability. (Figure adapted from Wildberg \& Möhring, 2021)

With increasing deviation between the borrowing and the lending rate, the maximum annual payout of the two transitions decreased. At a small deviation between borrowing and lending rates (close to a perfect capital market), the periodic transition was comparatively profitable. At an increased deviation between borrowing and lending rates, there was a switch in relative profitability, as the continuous transition became more profitable (see red circle in Fig. 13). This indicates, when considering an increased deviation between borrowing and lending rates (as can be expected in reality), it can be favorable to strive for a regular and even flow of timber production and income. 


\section{Discussion and concluding remarks}

Empirical accounting data is generally a useful tool to track operational development and identify factors for economic failure and success. Additional field studies can target specific empirical questions, while model simulations and profitability calculations allow to illustrate fundamental correlations and aid in rational decision making. To a certain extent, the individual studies of this thesis have made use of all the mentioned methods to analyze different aspects of some of the current challenges in forest enterprise economics.

Numerous studies have analyzed the possibilities and potentials for tree species diversification in forestry and forest enterprises particularly regarding the diversification effect based on Markowitz' (1952) portfolio selection theory (see e.g. Knoke et al., 2005; Knoke et al., 2008). The FAN Westfalen-Lippe provides a very suitable infrastructure to transform the idea of financial asset portfolios to forest enterprise portfolios consisting of tree species assets. The data showed varying intensities of tree species diversity in the forest enterprises based on the areal proportion of different tree species groups. The data indicated that the standardized tree species diversity (evenness, see Pretzsch, 2009, p. 279ff.) in the forest enterprises was negatively correlated with the mean contribution margin of the forest enterprises. These findings correspond to the notion that mixed forests can be considered less desirable for some forest owners (see Knoke et al., 2008). In contrast, the data also indicated a negative correlation between evenness and the volatility (standard deviation) of the mean contribution margins of the forest enterprises. Regarding the diversification effect, all forest enterprises showed a reduction in contribution margin volatility compared to the sum of the weighted contribution margin volatility of the underlying tree species groups. The strongest diversification effects were measured in the forest enterprises with the highest standardized tree species group diversity (the pine enterprises). However, these enterprises also showed the lowest contribution margins. The spruce enterprises generated the highest contribution margins and absolute volatility, which can be explained by the comparatively high contribution margins and standard deviation of the spruce species. Forest enterprises with a larger share of hardwood species and pine showed lower contribution margins but stronger diversification effects as the positive correlation between tree species groups was decreased. The observed results regarding the economic profitability of the tree species groups are conforming to previous studies. In Neuner et al. (2013) the spruce was the tree species yielding the highest profits (see also Knoke et al., 2005) and the pine acted as a diversifier.

The data demonstrated that the contribution margins of the tree species group were not stationary over time but showed an uptrend (spruce) or downtrend (beech and oak). After detrending the time series data, the correlation coefficient of the contribution margins between the tree species groups increased meaning they were more closely positively correlated. Respectively the measured diversification effects in the forest enterprises were lower after detrending the data. This shows, that it is necessary to check empirical time series data for trends regarding the interpretation of the diversification effect, as systematic risks are not considered (see Lukomnik \& Hawley, 2021). It would not be advisable to compensate an upward moving trend of one asset with a downtrend of another asset for the sake of diversification.

Similarly to Knoke et al. (2008) and Neuner et al. (2013) the findings of this study are not suitable to give specific recommendations as this would require specific owner risk and return preferences as well as insight on the ecological suitability of tree species. However, the study can 
provide an insight on the possibilities and the impact diversification can have on the economic performance of forest enterprises.

Besides a diversified tree species portfolio, forest enterprises can benefit from temporal diversification by managing age class diversity to secure regularity of income (see e.g. Hahn et al., 2014 ). Under perfect capital market conditions, forest owners/enterprises have no incentive for regular income (see Tahvonen, 1998; Tahvonen \& Viitala, 2006) as maximum wealth and maximum income coincide (see Kruschwitz \& Lorenz, 2019, p. 68, 73). However, an even flow or regularity of income is a fundamental component of sustainability in forest management (Speidel, 1972, p. 54). Furthermore, forest owners prefer to use their forest as a bank (Tahvonen et al., 2001) also for irregular non-forestry related purchases (see "Volvo argument" in Brazee, 2003; Johansson \& Löfgren, 1985, p. 138f.) and typically want to avoid external funding due to expensive capital (see Brazee, 2003). Additionally, operational success is not solely measured in profits, but a firm requires a certain degree of liquidity to be viable (Kruschwitz \& Lorenz, 2019, p. 205). In a perfect capital market model, however, a liquidity problem does not exist as it is assumed that an unlimited supply of capital can be obtained at a given fixed interest rate (Möhring \& Dieter, 2020). This interest rate is the guiding tool for rational investment decision making (Hering, 2017, p. 3f.). The interest rate reflects both the rate to which capital can be borrowed and lent (Möhring \& Dieter, 2020). The fundamental assumption of a constant interest rate is regularly applied to the FPO-rule as a solution for the optimal age to harvest a forest stand. The necessity and possibilities to consider imperfections in forest management can be found in various literature especially succeeding the work of Samuelson (1976). These imperfections include but are not limited to pure capital market imperfections such as credit rationing (Tahvonen, 1998) or differing interest rates (Murphy et al., 1977) but also take into account forest owner specific preferences (Binkley, 1981). Many of these studies show and indicate the profitability of regular (or smooth) timber harvest and income (Tahvonen, 1998; Uusivuori \& Kuuluvainen, 2001). The specific intention of study 4 was to analyze the influence the capital market assumption of a constant interest rate has on the optimal rotation age and show, how imperfect capital market conditions can explain the profitability of continuous timber production as seen in practice. The investive character of a forest enterprise transition towards an increased rotation age was illustrated by expanding the forest enterprise model with an external source for financing temporary losses of net timber income. As long as external capital is cheaper compared to the invested capital in the forest stand and land, it is profitable to finance the fixed capital externally. This fundamental idea applies to the concept of Pressler's indicator rate (Pressler, 1860), which indicates the optimal time of harvest when it is equal to the constant borrowing and lending interest rate (Möhring \& Dieter, 2020). By introducing a volume-dependent interest rate, the temporary loss of net timber income becomes increasingly expensive to the point where the marginal profitability of the capital in the forest stands is lower than the external capital cost. This explains why the profitability of continuous income becomes increasingly profitable as external funding becomes increasingly expensive due to a volume dependent interest rate. Thus, the study provides indications that a normal forest structure and a steady flow of income is beneficial in a financial environment which describes the reality of an imperfect capital market more closely.

The approach to consider differing borrowing and lending rates into forest management decisions has already been done by e.g. Murphy et al. (1977), Uusivuori and Kuuluvainen (2001) as well as Brazee (2003). Study 4 complements these works by specifically applying a capital-volume 
dependent interest rate to contrast a periodic versus a continuous flow of timber income within the normal forest framework. For further research it could be of value to expand the analysis of the influence of capital market imperfections such as taxes on the optimal forest rotation age and harvesting pattern. In study 4 , the liquidity problem is created by an imperfect capital market. It can therefore be more profitable for the forest enterprise to create a forest structure that provides regular income. As seen in study 3 regularity of income can be disrupted by calamity events resulting in missing funding for necessary silvicultural measures.

\subsection{Concluding remarks}

Forestry and sustainable forest enterprises will continue to face challenges that result in loss of income and devaluation of timber asset and enterprise value. Forest enterprises are required to find new strategies and alternatives to create resilient and profitable forests. Some implications and possible strategies have been addressed in this thesis. Forest enterprises can mitigate volatile income by means of tree species diversification. Furthermore, there is potential for forest enterprises to secure financial viability by finding alternatives apart from timber production income. These include further policy instruments in order to secure the continuity of operational income. 


\section{Study 1}

Title: Analysis of a long-term Forest Accountancy Network to Support Management and Controlling

\begin{tabular}{ll}
\hline Authors: & Markus Dög, Johannes Wildberg, Bernhard Möhring \\
\hline Published in: & Open Agriculture \\
\hline Year: & 2018 \\
\hline Impact score: & 1.20 \\
\hline DOI: & $\underline{\text { https://doi.org/10.1515/opag-2018-0016 }}$ \\
\hline Author contribution: & $\begin{array}{l}\text { The authors Markus Dög, Johannes Wildberg and Bernhard Möhring were } \\
\text { involved in publishing this study. Markus Dög conducted the analysis and } \\
\text { wrote the article together with Johannes Wildberg. Bernhard Möhring } \\
\text { supervised the publication process. }\end{array}$
\end{tabular}




\section{Research article}

Markus Dög*, Johannes Wildberg, Bernhard Möhring

\section{Analysis of a long-term Forest Accountancy Network to Support Management and Controlling}

https://doi.org/10.1515/opag-2018-0016

received February 28, 2018; accepted April 23, 2018

Abstract: Multifunctional forestry in Germany is characterized by long production periods and complex biological-technical processes. Private forest enterprises are complex systems which are closely interwoven with the economic environment. To ensure their economic success, forest landowners need to take the economic development into consideration and adapt their management strategies. Management accounting is an important source for information needed to fulfil main tasks of accounting that help to manage forest enterprises: 'description', 'explanation' and 'decision making'. To get general data, long time series data, taken from Forest Accountancy Networks (FAN), can be analysed. For more than 45 years, data from the FAN Westfalen-Lippe in Germany has been collected and analysed by the department of Forest Economics and Forest Management at the University of Göttingen. The long-term development and adaptation strategies of defined groups of private forest enterprises can be illustrated using this data. These valuable time series can support decision-making processes for private forest landowners and provide tools for forest policy. The data shows that private forest enterprises, with spruce as the dominating tree species, have performed above average in terms of operating revenues and profit margins, but are also more susceptible to calamities resulting in higher involuntary timber harvests.

Keywords: management accounting, tasks of accounting, forest accountancy network

\footnotetext{
*Corresponding author: Markus Dög, Department of Forest Economics and Forest Management, University of Göttingen, 37077 Göttingen, Germany, E-mail: markus.doeg@forst.uni-goettingen.de Johannes Wildberg, Bernhard Möhring, Department of Forest Economics and Forest Management, University of Göttingen, 37077 Göttingen, Germany
}

\section{Introduction}

Forests in Germany are the result of intergenerational economic activity. With almost $50 \%$ of total forest area (BMEL 2014), private forests are the dominant form of forest land ownership (33\% is state owned and 19\% is owned by municipalities). Private forests are generally managed by forest enterprises. Private forest enterprises are complex businesses typically operating at local level to offer goods and services on various markets for forest produce (see also Brandl 2002). Management strategies are under constant development to safeguard overall economic success and financial stability of the enterprise (Selchert 1997). A possible approach to develop new management strategies is in analyzing long term accounting data (Möhring et al. 2016; Bürgi et al. 2016a). This data can be obtained from so called Forest Accountancy Networks (in the following referred to as FAN), which comprise a number of forest enterprises (Brandl 2011, Wense 1990). Generally speaking, accounting monitors financial processes and tracks the flow of goods and funds. It is commonly divided into external financial reporting, which includes annual financial statements, and internal management accounting, which deals with cost-revenue analysis, company statistics and budgeting. It is of high importance that financial reporting is always in compliance with legal requirements. For management accounting, a business management perspective is necessary (Möhring et al. 2017).

The following article will deal with a total of three tasks associated with the concept of accounting:

Task 1: Description: What is the situation?

Task 2: Explanation: Why is the situation like that? What will it be?

Task 3: Decision making: What should be done? What are the factors of success?

The results of FANs, like that of Westfalen-Lippe in Germany, support the tasks of management and controlling (cf. Sekot 2017). Brabänder et al. (2001) describes a FAN as an instrument for monitoring economic efficiency of a 
forest enterprise. It can be used for objective evaluation of economic decision making. A FAN not only provides means of operational control but is also an important tool for future planning (see BMEL 2018; Lohner et al. 2016; Toscani and Sekot 2018). The following will demonstrate how this can be done in a scientific manner.

\section{FAN Westfalen-Lippe}

For more than 45 years, data from the FAN WestfalenLippe in Germany has been collected and analysed by the department of Forest Economics and Forest Management at the Georg-August-Universität Göttingen. The FAN was established in 1969 in cooperation between the federal state of Northrhine-Westfalia, the Landesbetrieb Wald $u$. Holz NRW, the Forest Farmers Association NRW and the University of Göttingen. It is one of the oldest and most extensive data sets for private forests in Germany. Now it consists of about 30 middle-sized and large private forest enterprises from North Rhine-Westphalia and bordering areas of Hesse and Lower-Saxony located in North-WestGermany. Ever since its establishment it has collected key financial indicators and tracked the growing stock of the participating forest enterprises. The average size of the enterprises is 1,600 ha. Most of the enterprises deliver annual reports to the network resulting in a nearly gapless set of data, which makes long term comparisons possible.
Regionally induced differences amongst enterprises are taken into account as the FAN is divided into different groups referred to as 'consultancy circles'. These groups are categorized by the enterprises' dominant tree species, which is either spruce (Picea abies), broad-leafed tree species (especially beech, Fagus sylvatica) or pine (Pinus sylvestris). The long-term management development and adaptation strategies of these groups can be derived from the collected data. These valuable time series can support decision-making processes for private forest landowners and provides tools for forest policy.

\subsection{Task 1: Description}

The current economic state of a forest enterprise can be described using different operating results (see Bürgi et al. 2016b; Bürgi and Pauli 2012). The following results of the FAN Westfalen-Lippe are averages of the various consultancy circles (with defined properties and sets of tree species) and therefore allow comparisons at operational level.

A key indicator for economic activity is the annual felling amount within a forest enterprise. As shown in Figure 1 (Dög et al. 2017) the amount of timber felled in spruce dominated enterprises was almost always at a higher level, compared with the other enterprises (aprox.

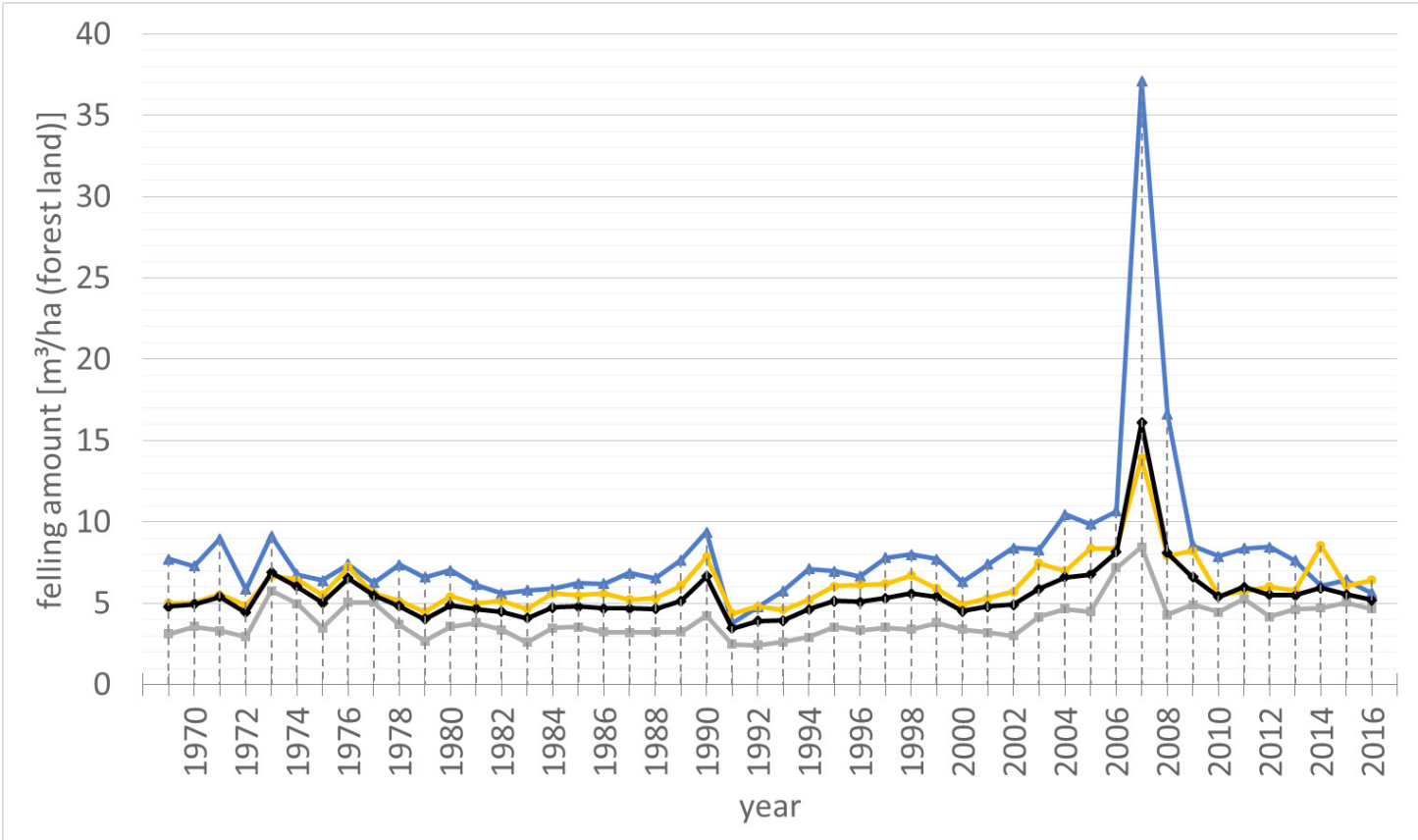

$\leftarrow$ spruce enterprises $\rightarrow$ broadleaf enterprises $\rightarrow$-pine enterprises $\rightarrow$ all enterprises 
$2.5 \mathrm{~m}^{3} /$ ha higher). Even though the most recent years show a decrease in the amount of timber harvested, spruce enterprises remain well within the total average of all participating enterprises. The peak in 2007 was caused by the storm 'Kyrill' which primarily affected the spruce dominated enterprises.

Not only is the amount of timber harvested important, but the costs and revenues of felling are of particular interest in regard to the operating results of the enterprises. Revenues result in multiplying the timber price with the harvested amount. Naturally, long-term revenues follow a similar trend to the harvested amounts with peaks in times of calamities (such as windstorms). Revenues (nominal values) over time were stable over the last years since 2009 and accumulated to approx. $350 € /$ ha in the year 2016 (see Figure 2). Figure 2 (Dög et al. 2016) also shows that spruce enterprises (especially compared to pine enterprises) show a more volatile trend. The reason being that spruce was more affected by storms in the years since 1990. The costs follow a smoother path with a slight increase over time. Costs increase during calamity years like 2007, where the spruce enterprises where greatly affected by the storm "Kyrill”.
To demonstrate the relation between income and expenses (nominal values), the chart shown in Figure 3 can be applied. It shows the relation between operating costs and revenues for the year 2015. In 2015 only four of the participating enterprises had higher costs than returns so that they are located in the so-called loss zone. There are however some really profitable enterprises (primarily spruce enterprises) as well.

\subsection{Task 2: Explanation}

Interpreting the results provided by the FAN and deriving prognoses for the future is the second task of accounting. An example of this is given in Figure 4, which shows the working hours of the employed forest workers in an enterprise that can be financed by the revenues per cubic meter of sold timber (financeable working hours). The financeable working hours do not consider timber which was harvested and sold in self-logging contracts. The development can be described as asymptotic and demonstrates the effect of how increased mechanization, rising labor costs (in addition to outsourcing of labor to

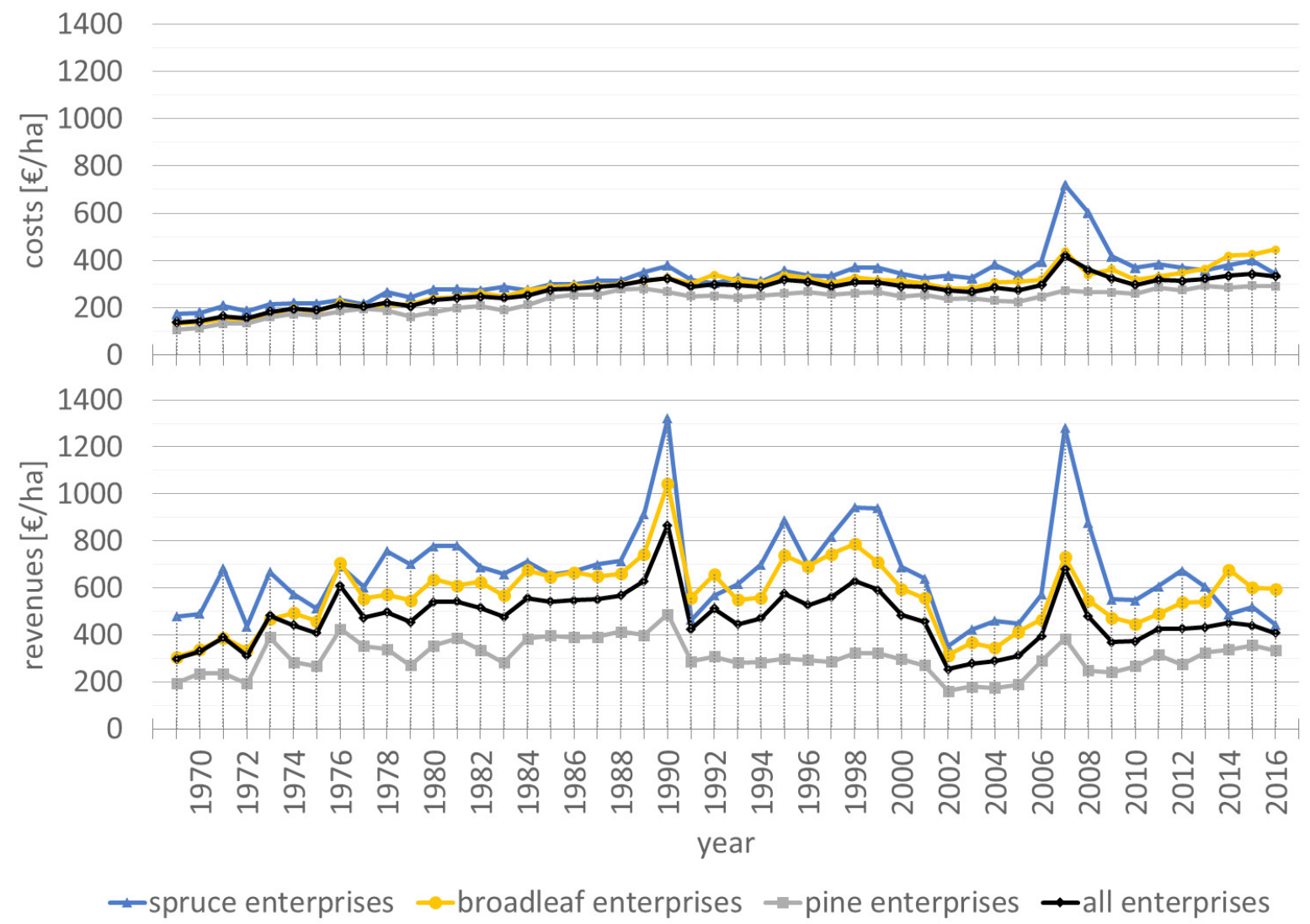

Figure 2: Costs and revenues per hectare forest land according to consultancy circles 
$\Delta$ spruce enterprises broadleaf enterprises pine enterprises

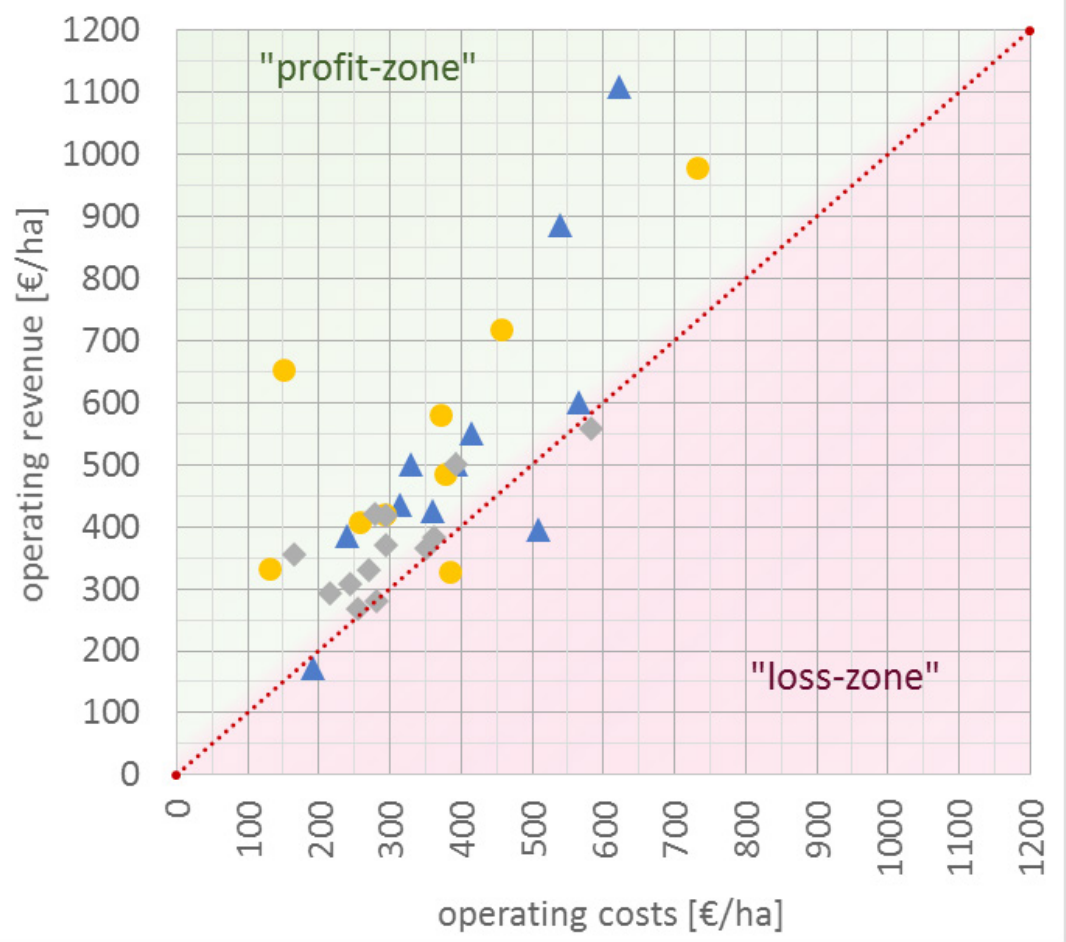

Figure 3: Income and expenses of the enterprises according to consultancy circles in 2015

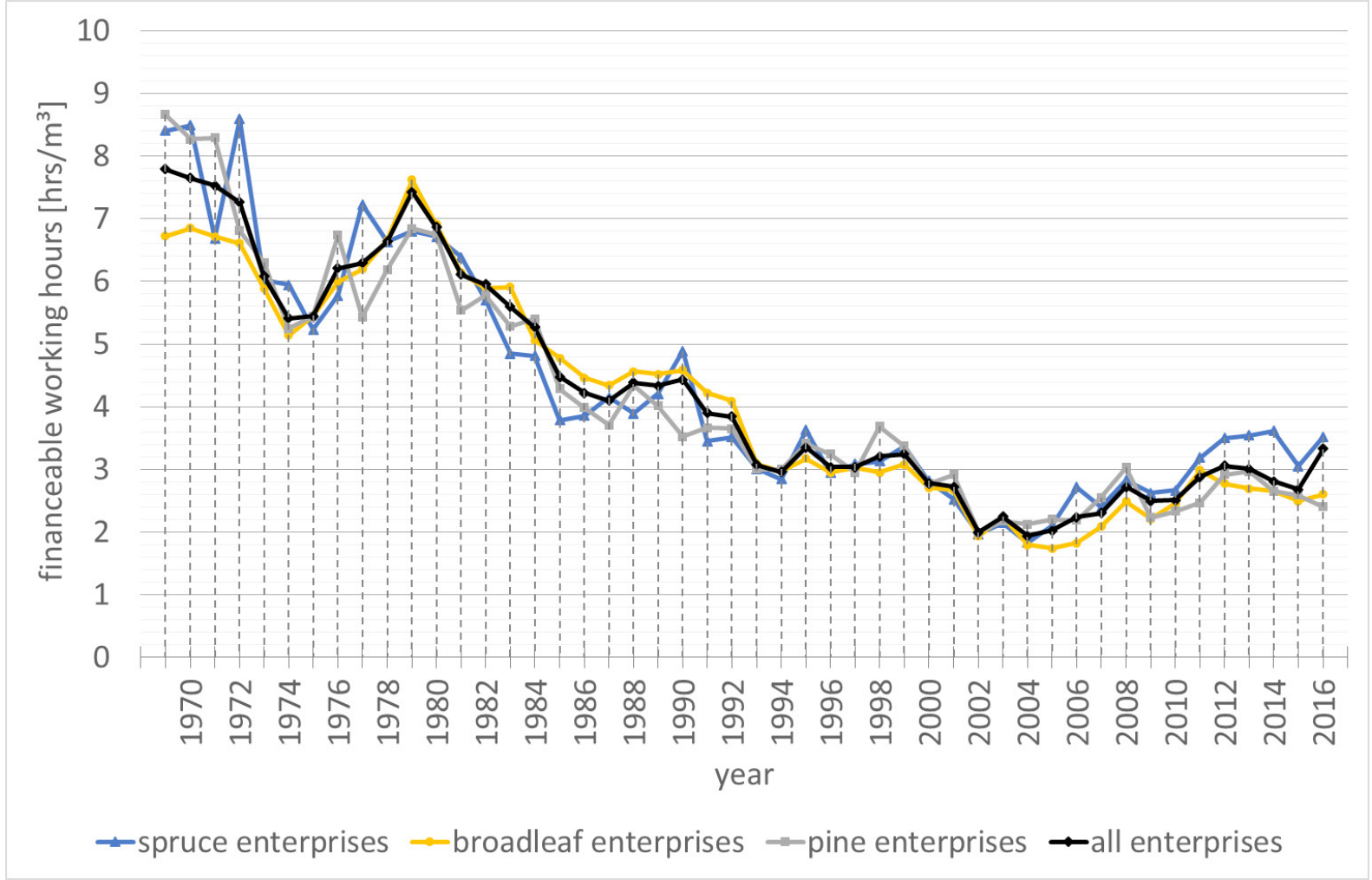

Figure 4: Financeable working hours according to consultancy circles 
contractors) and varying timber prices, results in fewer financeable working hours. While in 1969 a total of eight hours could be financed with the revenues of one cubic meter of timber (equivalent to labor costs of one working day), only two hours could be financed in the early 2000 s. Nowadays one cubic meter of timber is able to finance three working hours on average. That means despite outsourcing and receding numbers of employed forest workers, financeable working hours are declining because of higher wages, increased qualification of employees (mechanization) and a proportionally lower increase in timber prices. Following this trend, it can be expected that the value of $2 \mathrm{~h} / \mathrm{m}^{3}$ demonstrates a lower bound so that in the future about 2 to 3 working hours can be financed by the revenues of a cubic meter of timber. For operational planning with an employed workforce, the minimum amount of timber to be harvested, to compensate personnel expenses, can be derived from this information.

\subsection{Task 3: Decision Making}

From the enterprises' point of view, the third task of accounting is of high relevance as it provides indicators for decision making. The question which will be answered exemplarily here is: what are the factors of success? Therefore, the financial contribution of the dominating tree species to the operating results needs to be identified. This requires shifting the focus from comparing whole enterprises to comparing the results of different tree species. In Germany (and as well in FAN Westfalen-Lippe), results for the 4 main tree species 'oak', 'beech', 'spruce' and 'pine' are reported regularly. The financial return per hectare species-area of a harvest depends primarily on the felling quantity and secondly on the net timber revenue per cubic meter. These two figures are shown for the four main tree species below. Figure 5 shows the amount of timber harvested in relation to the amount of forest land area each species occupied. Since the figures are based on the area occupied by the trees it is not possible to derive the sum of the total harvest amount (like in Figure 1). That is why the harvested amount $\left(\mathrm{m}^{3}\right)$ is set in relation to land occupied (ha) by the species (speciesarea). It becomes apparent that the spruce harvest decreases significantly on the spruce land. The slight peak in 2014 in beech harvest can be attributed to a summer storm event that heavily hit broadleaf enterprises.

The net timber revenue per cubic meter after deducting harvesting costs is one of the most relevant economic ratios for forest enterprises. Figure 6 depicts the net timber revenue per cubic meter for the four main tree species over the last years. It becomes apparent that the revenues of oak wood $\left(\mathrm{m}^{3}\right)$ are comparatively high, though not constant over time. The revenues of spruce are on a constant high value only decreasing slightly during the last years. The revenues of beech are continuously on a low level.

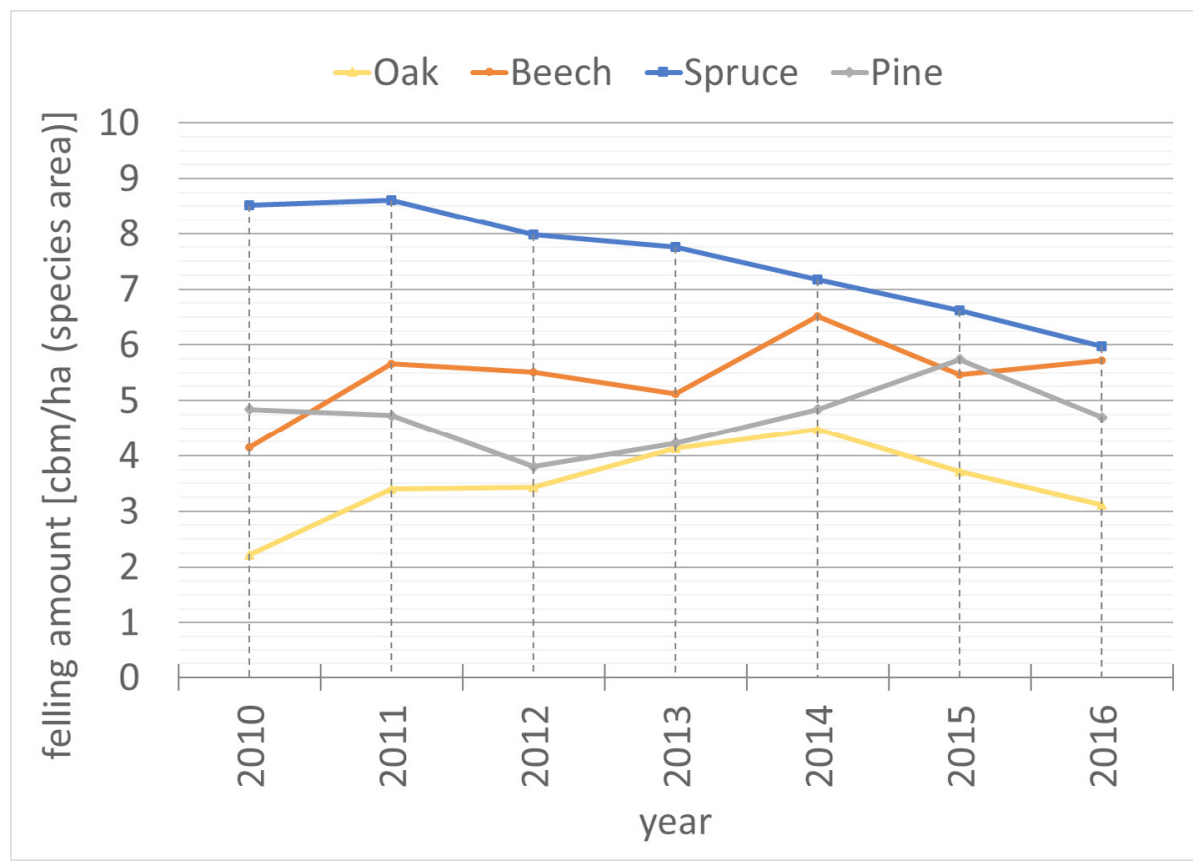

Figure 5: Felling amount per hectare according to main tree species 
The profit margin (revenue per hectare) is the mathematical product of timber harvest and net timber revenue. To determine the importance of the individual species, the graph in Figure 7 was created (Dög et al. 2016). It shows the profit margin of the dominating tree species in relation to the share of total forest land occupied by that species. Therefore, the width of the bars indicate the share of the forest land, whereas the bar height indicates the profit margin. Because of this the surface under the graph (profit multiplied with area) corresponds to the share of the total operating revenue. The black line shows the mean profit margin over all species and total forest land (in this case all forest enterprises). It becomes apparent that spruce is the most relevant species within the FAN Westfalen-Lippe.

Using this knowledge for operational decision making can aid for instance in tree species selection (task: 'decision making'). The beech for example is highly

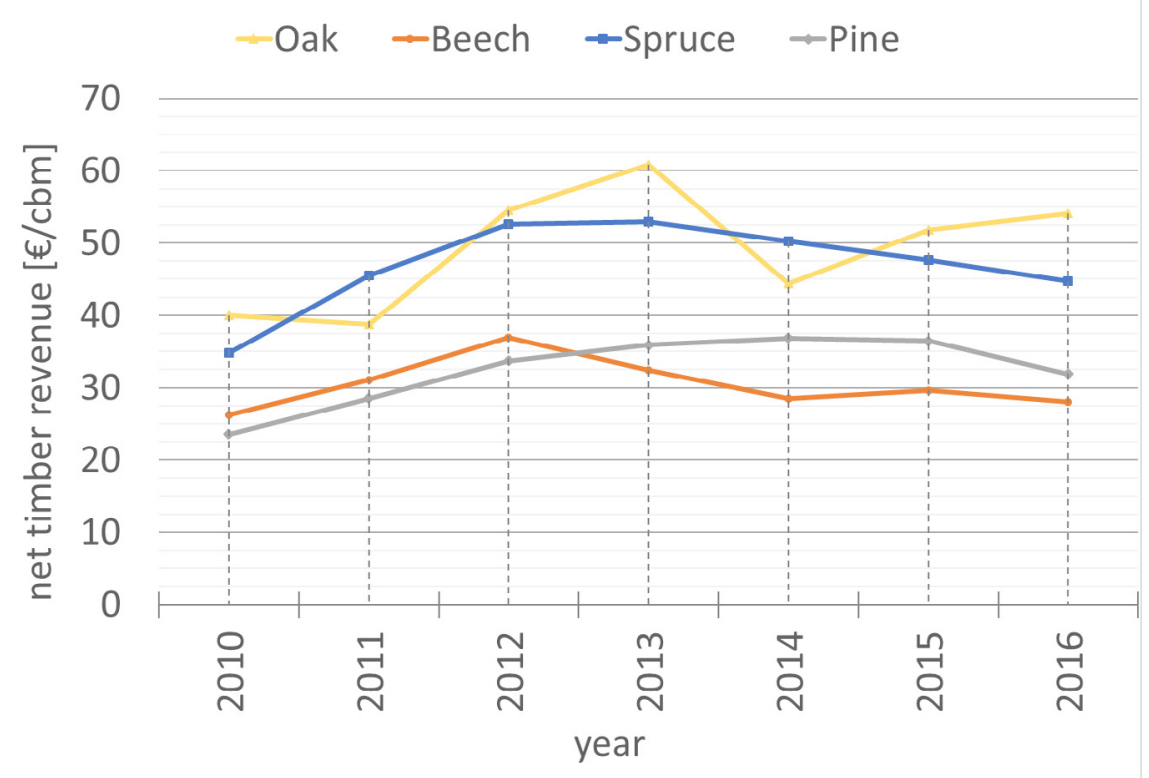

Figure 6: Net timber revenue per cubic meter according to main tree species

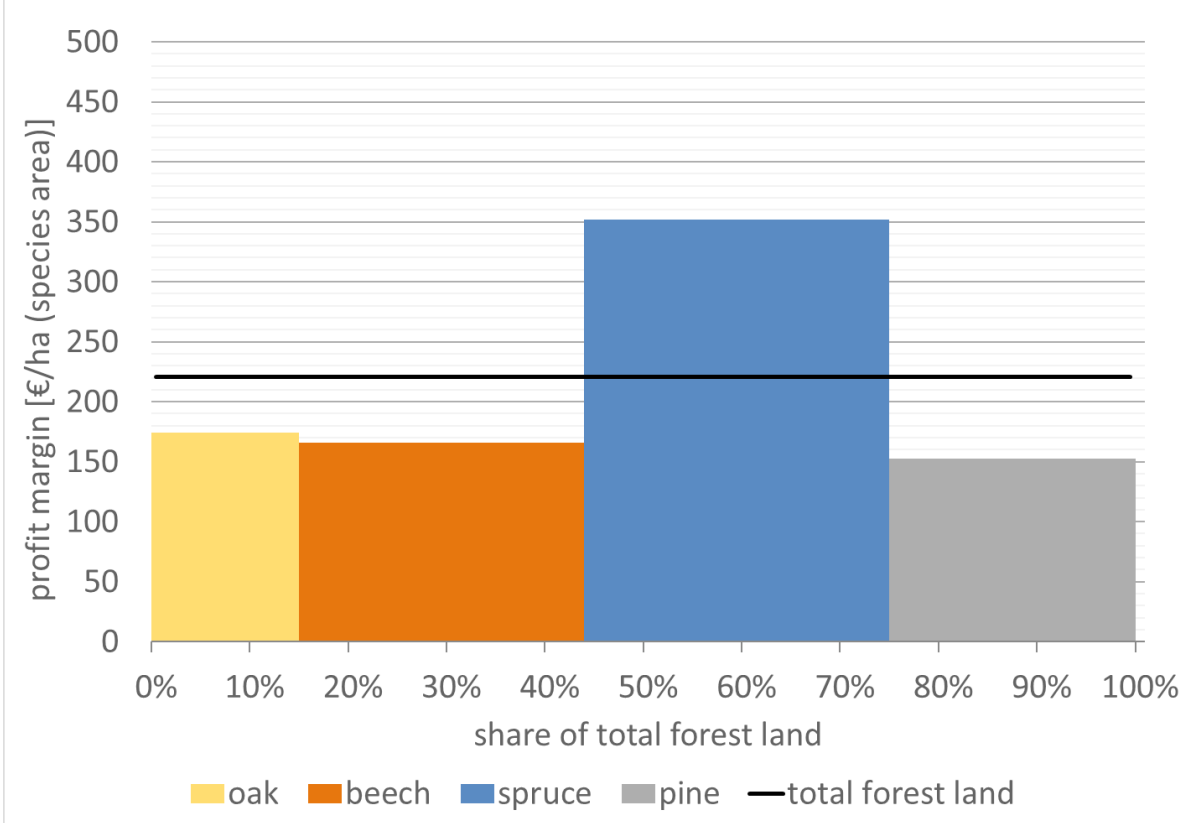

Figure 7: Profit margin per hectare according to main tree species (average 2010-2016) 
praised in central Europe and specifically in Germany in regard to both nature conservation and silviculture. The results of the FAN Westfalen-Lippe suggest however, that over time and on average of all enterprises, the beech can only mildly contribute to a positive operating income. On average, the spruce generated by far the highest operating income per hectare of species-area and contributed over-proportionally to the overall economic success. Comparable results can be found in Ermisch et al. (2013). They determined that the spruce contributed the highest to the total timber revenue in Germany between 2003 and 2011. Griess and Knoke modelled comparable results for mixed spruce-beech-stands with more than $50 \%$ beech. Regarding climatic change however, it may be necessary to replace the spruce in the long term and establish a broad-leafed species like beech (Bolte 2016; Bolte et al. 2010; Panferov et al. 2009; Kölling et al. 2007). From an economic perspective it would be advisable to resort to tree species, which can produce an equivalent operating income (see also Neuner and Knoke 2017; Knoke 2009). Griess and Knoke (2013) modelled comparable results for mixed spruce-beech-stands with more than $50 \%$ beech.

\section{Conclusions}

Data from forest accountancy networks provide varied information of the past and can deliver valuable insights for future management. Participating forest enterprises, forest economic research as well as forest politics can therefore benefit from this data (see Sekot 2017; Sekot et al. 2010; Filbrandt 2005). There are however several possibilities for evaluation and interpretation. Firstly, a classical comparison of different enterprises must be mentioned. Secondly, a type of operating branch settlement (like those known in agriculture) seems to be appropriate. A suitable basis for this could be main tree species with reference to the species-area. With the data from the FAN Westfalen-Lippe such an analysis was shown. In result of this analysis the most important tree species for the participating enterprises could be identified. On average the species spruce achieved the highest revenues (per hectare). From a business point of view, however, tree species that can sustainably provide adequate contribution margins should always be preferred. Such information can be used in decision making for managing individual enterprises as well as political consultation.

\section{References}

BMEL, Der Wald in Deutschland. Ausgewählte Ergebnisse der dritten Bundeswaldinventur, 2014, https://www.bmel-statistik.de// fileadmin/user_upload/017_Holz-und_Forstwirtschaft/Bundeswaldinventur3.pdf, (in German)

BMEL, Die wirtschaftliche Lage der forstwirtschaftlichen Betriebe. Buchführungsergebnisse des Forstwirtschaftsjahres 2016, 2018, https://www.bmel-statistik.de//fileadmin/user_upload/ monatsberichte/BFB-0113002-2016.pdf, (in German)

Bolte A., Hilbrig L., Grundmann B., Kampf F., Brunet J., Roloff A., Climate change impacts on stand structure and competitive interactions in a southern Swedish spruce-beech forest, European Journal of Forest Research, 2010, 129(3), 261-276

Bolte A., Chancen und Risiken der Buche im Klimawandel, AFZ Der Wald, 2016, 71(12), 17-19, (in German)

Brandl H., The Economic Situation of Family-farm Enterprises in the Southern Black Forest, Small-scale Forest Economics, Management and Policy, 2002, 1(1), 13-24

Brandl H., Experiences in Collecting Data on Farm Forest Enterprises over More than Three Decades, Small-scale Forestry, 2011, 10, 135

Brabänder H.D., Kaul R., Freiherr von dem Bussche-Kessell A., Leefken G., Freiherr von Fürstenberg H., Grünert S., Hoffmann S., Graf von Nesselrode D., 30 Jahre forstlicher Betriebsvergleich, Druck- und Verlagshaus Bitter GmbH \& Co, Recklinghausen, 2001, (in German)

Bürgi P., Pauli B., Schweizer Waldwirtschaft vor großen Herausforderungen, Wald und Holz, 2012, 93(5), 19-21, (in German)

Bürgi P., Sekot W., Ermisch N., Pauli B., Möhring B., Toscani P., Forstbetrieblicher Kennzahlenvergleich Deutschland - Österreich - Schweiz. Schweizerische Zeitschrift für Forstwesen, 2016, 167(2), 73-81, (in German)

Dög M., Möhring B., Wrede E., Der Privatwald-Betriebsvergleich Westfalen-Lippe im WJ 2015, AFZ-Der Wald, 2016, 71(23), 32-34, (in German)

Dög M., Möhring B., Wrede E., Der Privatwald-Betriebsvergleich Westfalen-Lippe im WJ 2015, AFZ-Der Wald, 2016, 71(23), 32-34, (in German)

Dög M., Möhring B., Wrede E., Ellermann W., Der PrivatwaldBetriebsvergleich Westfalen-Lippe im Jahr 2016, AFZ-Der Wald, 2017, 72(23), 31-33, (in German)

Ermisch N., Seintsch B., Dieter M., Holzartengruppe Fichte 2003 bis 2011 konstant mit höchstem Erlösbeitrag, AFZ Der Wald, 2013, 68(23), 6-9, (in German)

Fillbrandt T., Das Testbetriebsnetz Forstwirtschaft als Instrument der Politik und der Betriebsführung, http://www.waldwissen.net, 2005, (in German)

Griess V.C., Knoke T., Bioeconomic modeling of mixed Norway spruce - European beech stands: economic consequences of considering ecological effects, European Journal of Forest Research, 2013, 132(3), 511-522

Knoke T., Die ökonomische Zukunft der Fichte, LWF Wissen: Fichtenwälder im Klimawandel, 2009, 63, 16-21, (in German)

Kölling C., Zimmermann L., Walentowski H., Klimawandel: Was geschieht mit Buche und Fichte?, AFZ Der Wald, 2007, 62(11), 584-588, (in German) 
Lohner P., Appel V., Dieter M., Seintsch B., Das TBN-Forst: Ein Datenschatz für die deutsche Forstwirtschaft, AFZ Der Wald, 2016, 71(17), 10-11, (in German)

Möhring B., Wilhelm S., Dög M., The Relevance of Economic Data from Forest Accountancy Networks for Forest Management, Research and Politics Consultation, Small-scale Forestry, 2018, $17,25-40$

Möhring B., Wilhelm S., Dög M., TBN-Daten für Betriebssteuerung, Forschung und Politikberatung, AFZ Der Wald, 2016, 71(17), 12-15, (in German)

Neuner S., Knoke T., Economic consequences of altered survival of mixed or pure Norway spruce under a dryer and warmer climate, Climatic Change, 2017, 140(3-4), 519-531

Panferov O., Kreilein H., Meesenburg H., Eichhorn J., Gravenhorst G., Climatic Condition at Three Beech Forest Sites in Central Germany, In: Brumme R., Khanna P.K. (eds) Functioning and Management of European Beech Ecosystems. Ecological Studies, 2009, 208
Sekot W., Fillbrandt T., Zesiger A., Improving the International Compatibility of Accountancy Data: The 'DACH-Initiative', Small-scale Forestry, 2010, 10, 255-269

Sekot W., Forest Accountancy Data Networks as a Means for Investigating Small-Scale Forestry: A European Perspective, Small-scale Forestry, 2017, 16, 435-449

Selchert F. W., Einführung in die Betriebswirtschaftslehre in Übersichtsdarstellungen, 6th ed., Oldenbourg, München, Wien, 1997, (in German)

Toscani P., Sekot W., Forest Accountancy Data Networks-A European Approach of Empirical Research, Its Achievements, and Potentials in Regard to Sustainable Multiple Use Forestry, Forests, 2018, 9(4), 220, doi:10.3390/f9040220

Wense W-H., Der Betriebsvergleich in der Forstwirtschaft: Methoden zur Analyse forstwirtschaftlicher Kennziffern am Beispiel des Privatwaldvergleichs Westfalen-Lippe, PhD thesis, Georg-August-Universität Göttingen, Göttingen, Germany, 1990, (in German) 


\section{Study 2}

Title: $\quad$ Empirical analysis of the economic effect of tree species diversity based on the results of a forest accountancy data network

\begin{tabular}{ll}
\hline Authors: & Johannes Wildberg, Bernhard Möhring \\
\hline Published in: & Forest Policy and Economics \\
\hline Year: & 2019 \\
\hline 5-year impact factor: & 3.665 \\
\hline DOI: & https://doi.org/10.1016/j.forpol.2019.101982 \\
\hline
\end{tabular}

Author contribution: The authors Johannes Wildberg and Bernhard Möhring were involved in publishing this study. Both authors developed the idea and the conceptual approach of the study. Johannes Wildberg wrote the article under the supervision of Bernhard Möhring. 


\title{
Empirical analysis of the economic effect of tree species diversity based on the results of a forest accountancy data network
}

\author{
Johannes Wildberg*, Bernhard Möhring \\ Department of Forest Economics, University of Göttingen, Büsgenweg 3, 37077 Göttingen, Germany
}

\section{A R T I C L E I N F O}

\section{Keywords:}

Diversification effect

Forest enterprise management

Tree species risk

Modern portfolio theory

\begin{abstract}
A B S T R A C T
The selection of tree species for the establishment of forest stands can be regarded as a financial investment with long-lasting economic consequence. This study applies empirical forest enterprise accounting data to investigate the theoretical concept of the diversification effect and its practical implications for forest tree species diversity. Based on the data of a forest accountancy data network in Germany, the effect of tree species diversity on risk and return was analyzed. The data revolves around the most relevant tree species groups in Germany including Norway spruce (Picea abies L. Karst), European beech (Fagus sylvatica L.), oak (Quercus spec.) and Scots pine (Pinus sylvestris L.). The data demonstrated a positive diversification effect as tree species diversity in forest enterprises was negatively correlated with the volatility of return. The observed volatility of return in forest enterprises was lower than the weighted return volatility of their underlying tree species. Analysis of the individual returns and volatilities revealed that the spruce generated the highest economic return and highest absolute volatility followed by the hardwood species and the pine. Furthermore, we showed that the premises behind the theory of the diversification effect are not always consistent with empirical data, particularly in regard to the stationarity assumption of times series.

In summary, our empirical data supports the theory in that forest enterprises with a diversified tree species composition will not yield the highest returns possible, but are able to minimize risk for a given level of return. However, the non-stationary development of tree-species-assets as well as risk preferences need to be considered in management decisions.
\end{abstract}

\section{Introduction}

The establishment of forest stands in forest enterprises is a matter of financial investment. Ideally, the investors' operational and strategic objectives are reflected in the selection of tree species. The optimal tree species selection balances investment risk and return in a subjectively efficient manner. While the optimal tree species selection remains a theoretical concept, decision makers in forestry are looking for practical solutions to avoid risk and promote economic return.

The so-called diversification effect provides a tool to manage a specific type of risk-return tradeoff in forestry, which is the volatility versus the amount of economic return (Knoke et al., 2005). Studies have repeatedly emphasized the advantages of the diversification effect in forestry by applying Markowitz's (1952) portfolio theory to tree species selection (e.g. Brunette et al., 2014; Knoke, 2008; Neuner et al., 2013). As portfolio theory (resp. the diversification effect) is designed to determine future investment behavior based on historical performance, empirical data is required. However, long-term empirical forest enterprise data is rarely available (Möhring et al., 2018) or sparse (e.g. Dragicevic et al., 2016), so the studies typically resort to simulations of the diversification effect (e.g. Knoke and Wurm, 2006; Knoke et al., 2005). This however involves the danger of blurring the line between what we know for certain and what we have to assume. Therefore, our study aims to provide empirical verification and quantification of the diversification effect associated with mixing tree species at the enterprise level to complement the previous works. Furthermore, we intend to show the extent to which our empirical data is consistent with the premises behind the theory of the diversification effect, particularly in regard to the stationarity assumption of times series. In this context we analyze how adjusting our data to match the theory's premises can affect the way we interpret the effect of tree species diversification.

We used economic data from the oldest forest accountancy data network (FAN) in Germany to determine the effect of tree species diversification on risk and return in private forest enterprises. Over a time span of 30 years, we examined the differences between forest enterprises in the composition of the growing stock and connected these

\footnotetext{
* Corresponding author.

E-mail addresses: johannes.wildberg@uni-goettingen.de (J. Wildberg), bmoehri@gwdg.de (B. Möhring).
} 


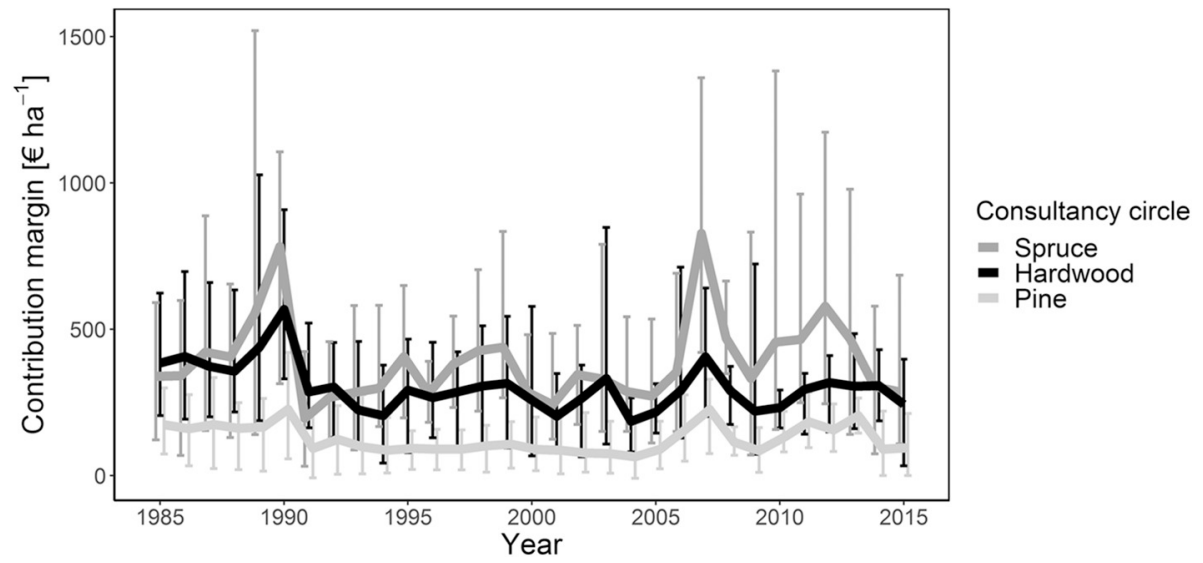

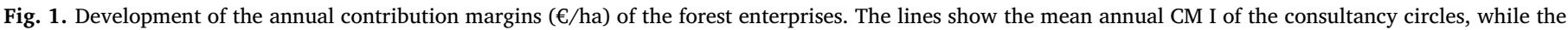
bars illustrate the respective range of the maximum and minimum annual CM I of the forest enterprises.

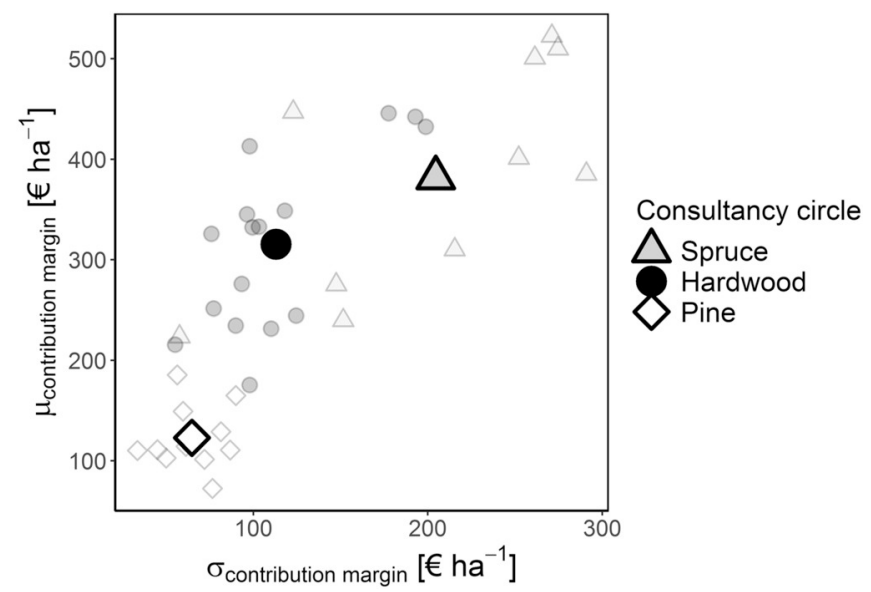

Fig. 2. Mean $(\mu)$ vs. deviation ( $\sigma$ ) distribution of the annual CM I of the forest enterprises I individually (small points) and grouped by consultancy circle (large points) taken from the results of Fig. 1.
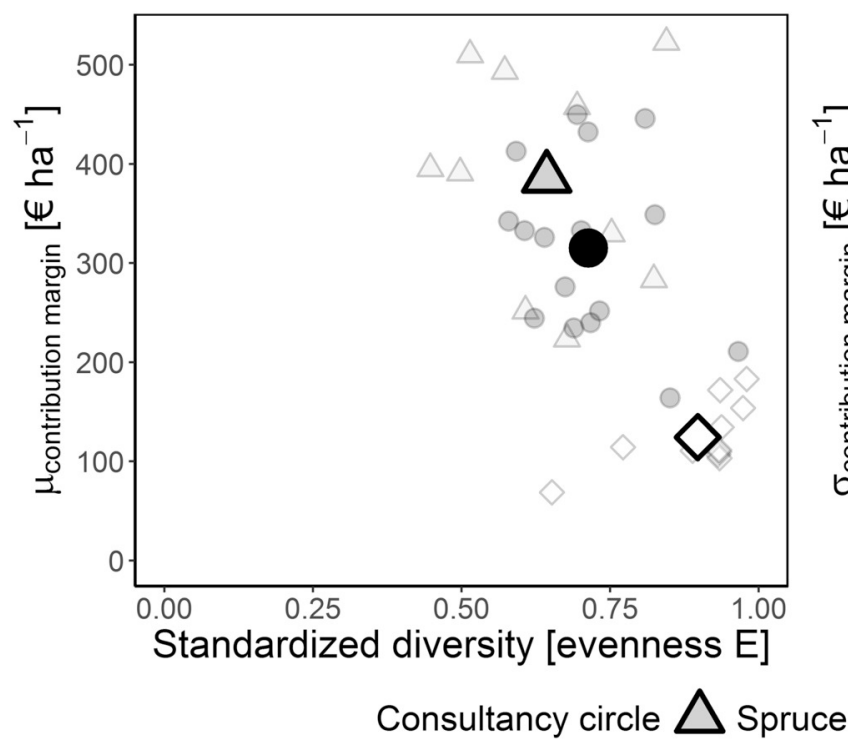

differences with the economic performance of the forest enterprises as a whole and the underlying tree species separately. Our study begins with a theoretical overview of the diversification effect in the context of forest economics. We then proceeded to apply the theoretical approach to our empirical data. This contrast between theory and practice allowed us to critically reflect on the premises behind the diversification effect and discuss its implications and applicability to forest enterprise economics.

\section{Theoretical framework and methods}

\subsection{Expected return and risk}

Quantifying risk as a measure of uncertainty in return is a fundamental method most prominently reviewed in both Markowitz (1952) and the capital asset pricing model (Sharpe, 1964). Risk can be measured by the volatility of empirical returns over a period of time. In German forest economics, the contribution margin I (CM I) describes the return on timber sales minus the harvesting costs (not including indirect costs) (Speidel, 1967). In our study, the standard deviation $\sigma$ determines the variation of $n$ annual contribution margins $x_{i}$ around

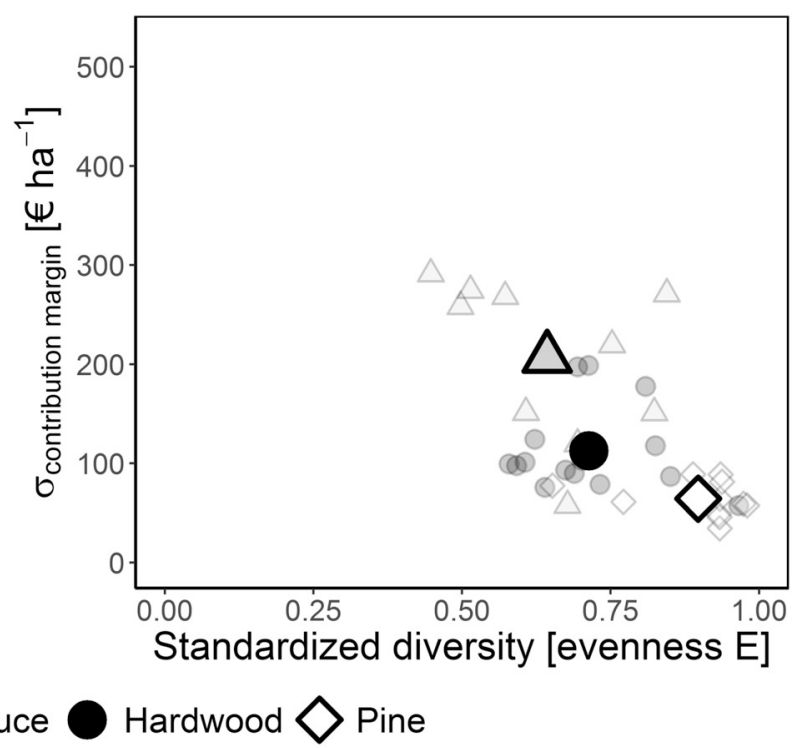

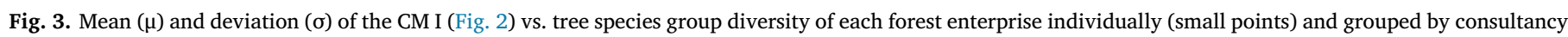
circle (large points). 

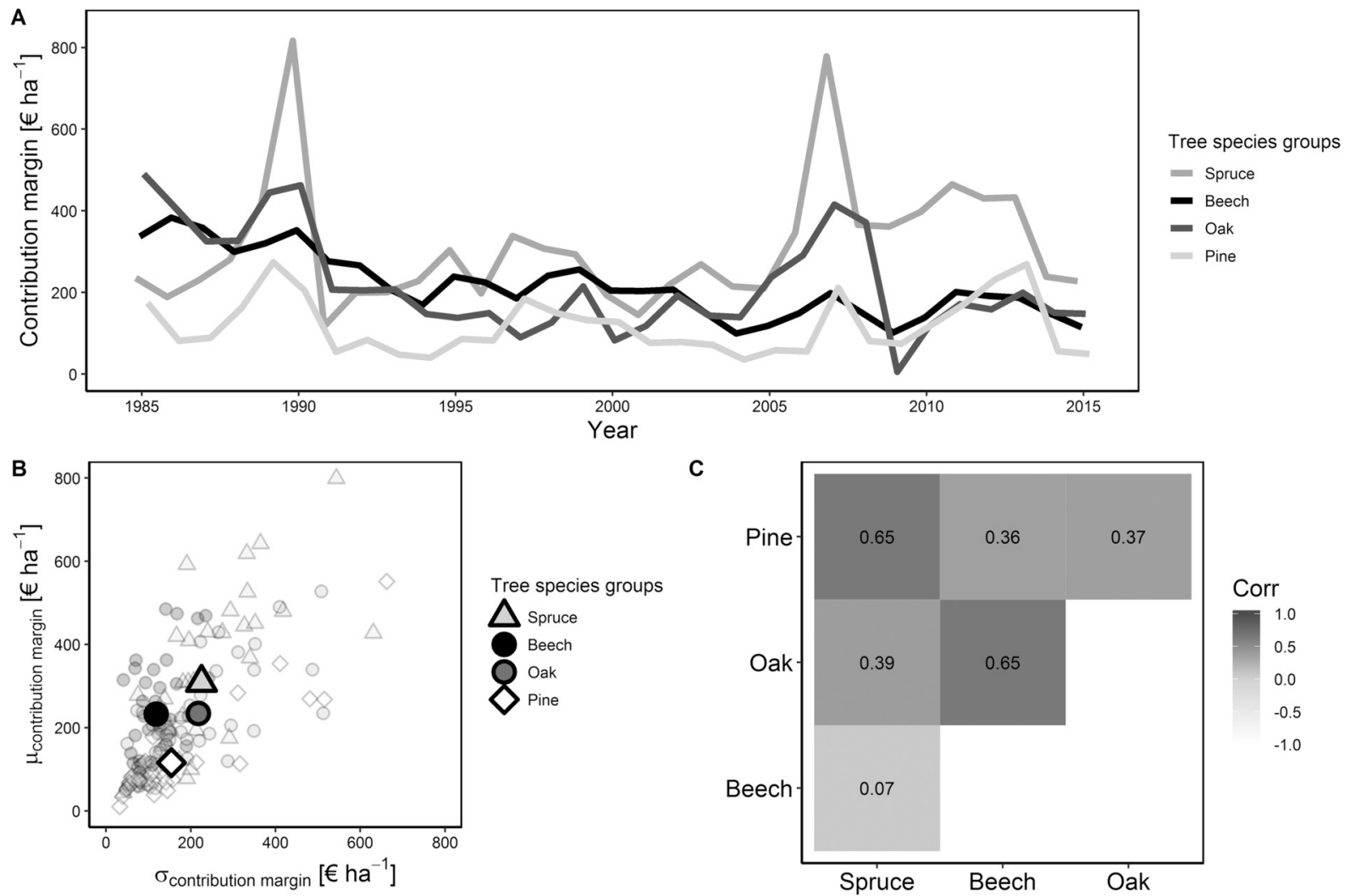

Fig. 4. (A) Mean development of the annual contribution margins ( $€ /$ ha) of the tree species groups of the forest enterprises. (B) Mean ( $\mu$ ) vs. deviation ( $\sigma)$ distribution of the annual CM I of the tree species groups of the forest enterprises individually (small points) and grouped by tree species group (large points). (C) Matrix showing the correlation coefficients between the CMs I of the tree species groups.

their mean $\mu$ (expected value). The standard deviation is a typical empirical measure to describe volatility (Knoke, 2012).

$\sigma=\sqrt{\frac{\sum_{i}\left(x_{i}-\mu\right)^{2}}{n-1}}$

Risk and return can be quantified based on empirical data assuming they are stationary over time (Brockwell and Davis, 2016, p. 43). Nonstationary time series with deterministic or stochastic trends need to be adjusted accordingly to avoid spurious assessment of risk and return for future reference.

Generally, if investors are risk-averse, they must accept lower returns, but can expect higher returns, if they are willing to take higher risks (Sharpe, 1964). This also applies to forestry, where a strong connection between risk and return can be observed (e.g. Möhring et al., 2011). As increasing return without increasing risk (and vice versa) typically contradicts economic theory, investors pursue a socalled risk-adjusted return, which can be achieved through diversification (Hight, 2010).

\subsection{Reducing risk using diversification}

Diversification is generally defined by the allocation of a portfolio consisting of a number of assets. The motivation behind diversifying one's assets lies in the so-called diversification effect, which is the reduction of non-systematic portfolio risk (Gibson, 1990; Perold, 2004; Hight, 2010). An overview on the various levels to apply the concept of diversification to forest economics has been conducted by Beinhofer (2009). One of these levels describes the forest to act as an investment portfolio stocked with multiple (tree species) assets (Knoke et al., 2017). In the context of forest management, Knoke et al. (2017) reviews numerous drivers for diversification such as multifunctionality (e.g. Gamfeldt et al., 2013), site quality (e.g. Marutani, 2010) or beneficial tree species interactions in mixed forest stands (e.g. Knoke et al., 2008; Roessiger et al., 2013; Neuner et al., 2015). In the classical sense however, the diversification effect merely describes the reduction in portfolio risk through imperfect correlations between asset returns (Hight, 2010). In this context, Figge (2004) suggested to apply this fundamental idea to portfolios of species. In our study, this portfolio is a forest enterprise, where the forest land is subdivided into areas (ha) of four different tree species groups. Looking at the specific conceptual background of how diversification may reduce forest-enterprise-portfolio-risk, requires an understanding of the general dependency of risk on tree species diversity. This requires measures to define and quantify tree species diversity first.

\subsection{Tree species diversity}

An established method to quantify tree species diversity is the Shannon diversity index. It was developed by Shannon and Weaver (1949) and later adapted to quantify species diversity in ecosystems (Pretzsch, 2009). Eq. (2) including its interpretation can e.g. be found in the work of Pretzsch (2009).

$E=\frac{H}{H^{\max }} * 100$

with

$H=-\sum_{i=1}^{S} \omega_{i} * \ln \omega_{i}$

$H^{\max }=\ln S$

In our study, the standardized diversity $E$ is expressed by the quotient of the tree species group diversity $H$ and the maximum diversity $H^{\max }$ and is referred to as evenness. The Shannon index $H$ is based on the number of tree species groups present $S$, where $\omega_{i}$ is the proportion of the tree species group in the enterprise's forest land area. $H^{\max }$ 

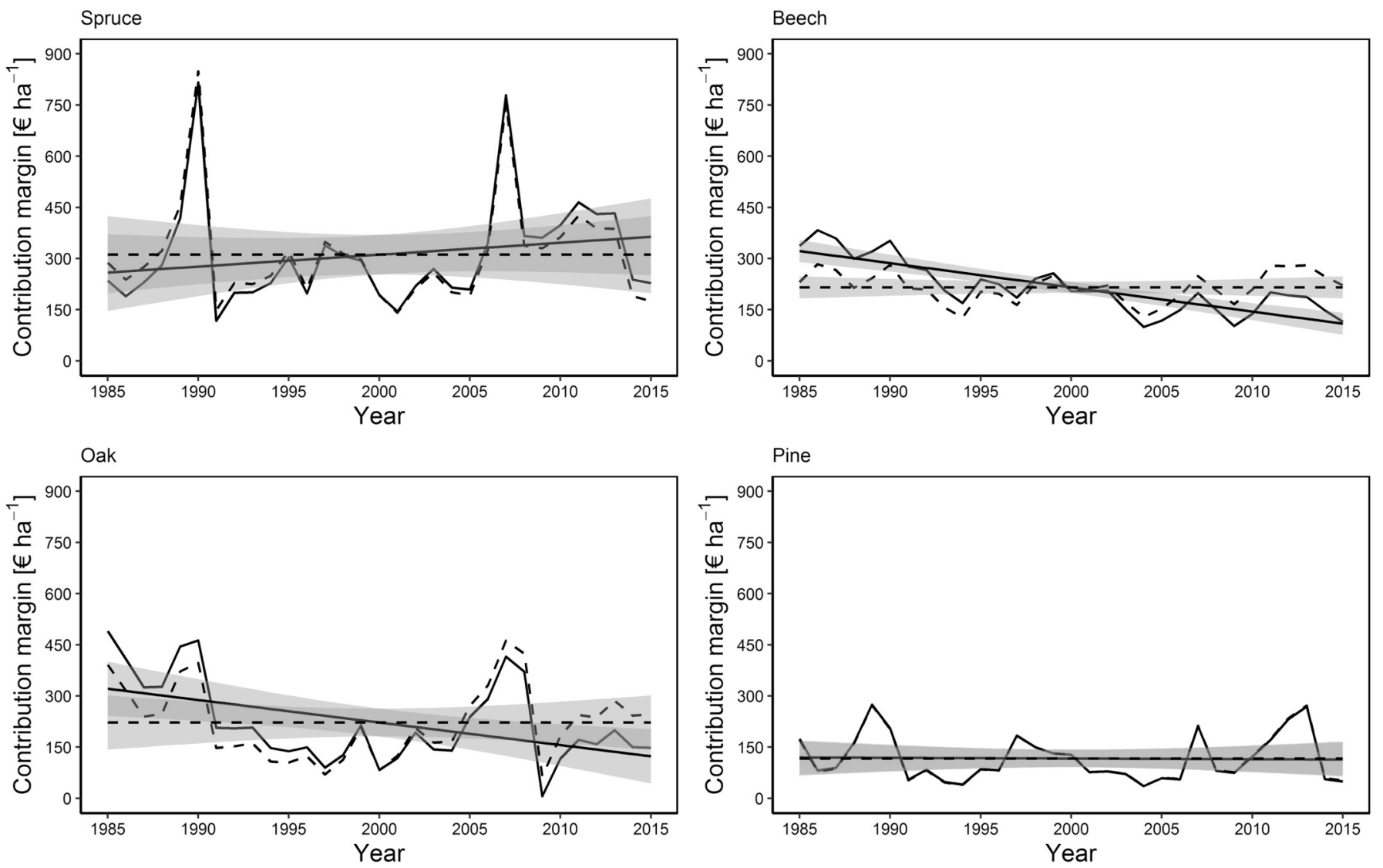

\section{- - Detrended - Undetrended}

Fig. 5. Undetrended and detrended mean development of the annual contribution margins $(€ /$ ha) of the tree species groups of the forest enterprises.

describes the maximum diversity for a given number of tree species groups. Maximum evenness $E=1$ is achieved, when the proportion of each tree species group is the same in the forest enterprise. As tree species group diversity decreases, evenness ultimately reaches 0 .

\subsection{Diversification effect}

Given that diversity reduces risk and reduced risk leads to reduced economic return (Sharpe, 1964), it stands to reason that diversity leads to a reduction in economic return. Önal (1997) describes this as the tradeoff between diversity and economic objectives. In this context, the diversification effect is not only about reducing risk, but reducing risk for a given level of return and therefore creating risk-adjusted return (Hight, 2010). This effect can be explained by looking at the risk of a portfolio. Eq. (3) describes an exemplary four-asset portfolio showing the volatility of the return of a forest enterprise $\sigma_{p}$. The standard deviations $\sigma$ of each asset's returns (i.e. the returns per tree species group a-d) are weighted according to the assets' proportional area $\omega$ in the enterprise-portfolio. Furthermore, the equation considers the correlation $\rho$ of each asset's returns with returns of every other asset in the portfolio. According to Hight (2010) and Markowitz (1952), the portfolio deviation can be decomposed into the individual variances and all respective covariances.

$\sigma_{p}=\sqrt{\begin{array}{l}\omega_{a}^{2} \sigma_{a}^{2}+\omega_{b}^{2} \sigma_{b}^{2}+\omega_{c}^{2} \sigma_{c}^{2}+\omega_{d}^{2} \sigma_{d}^{2}+2 \omega_{a} \omega_{b} \sigma_{a} \sigma_{b} \rho_{a b}+2 \\ \omega_{a} \omega_{c} \sigma_{a} \sigma_{c} \rho_{a c}+ \\ 2 \omega_{a} \omega_{d} \sigma_{a} \sigma_{d} \rho_{a d}+2 \omega_{b} \omega_{c} \sigma_{b} \sigma_{c} \rho_{b c}+2 \omega_{b} \omega_{d} \sigma_{b} \sigma_{d} \rho_{b d}+2 \\ \omega_{c} \omega_{d} \sigma_{c} \sigma_{d} \rho_{c d}\end{array}}$

The correlation between assets must be a value between -1 (perfect negative correlation) and 1 (perfect positive correlation). Perold (2004) describes this as the nonlinear combination of risk, given that not all correlations between the assets are 1. On the other hand, the expected return of that same four-asset forest-enterprise-portfolio $\mu_{p}$ is expressed as follows (adapted from Markowitz, 1952):

$\mu_{p}=\omega_{a} \mu_{a}+\omega_{b} \mu_{b}+\omega_{c} \mu_{c}+\omega_{d} \mu_{d}$

The return of the portfolio is just the sum of the weighted expected returns of each asset (i.e. the mean annual returns $\mu$ per tree species group a-d, weighted with their respective proportional area $\omega$ in the enterprise). This shows that the return combines linearly (cf. Perold, 2004). It follows from Eq. (4), that the expected return is not affected by whether or not the assets are mixed as part of a portfolio. Eq. (3) shows that the combined asset risk is lower than the sum of the assets' individual risks, given there is no perfect positive correlation. In theory, diversification thus provides the effect of reducing risk while maintaining a given level of expected return.

\subsection{Quantifying the diversification effect}

The mere observation of the diversification effect does not disclose the amount of risk reduction in a portfolio. Both Cheng and Roulac (2007) as well as Choueifaty and Coignard (2008) suggest the use of ratios between observed portfolios risk $\sigma_{p}$ compared to the sum of weighted risks of the underlying assets $\omega_{i} \sigma_{i}$ to quantify the diversification effect. Eq. (5) has been adapted from Hight (2010) and quantifies the amount of risk being reduced on a scale from 0 to 1 :

Diversification ratio $=1-\left(\frac{\sigma_{\mathrm{p}}}{\omega_{\mathrm{a}} \sigma_{\mathrm{a}}+\omega_{\mathrm{b}} \sigma_{\mathrm{b}}+\omega_{\mathrm{c}} \sigma_{\mathrm{c}}+\omega_{\mathrm{d}} \sigma_{\mathrm{d}}}\right)$ 

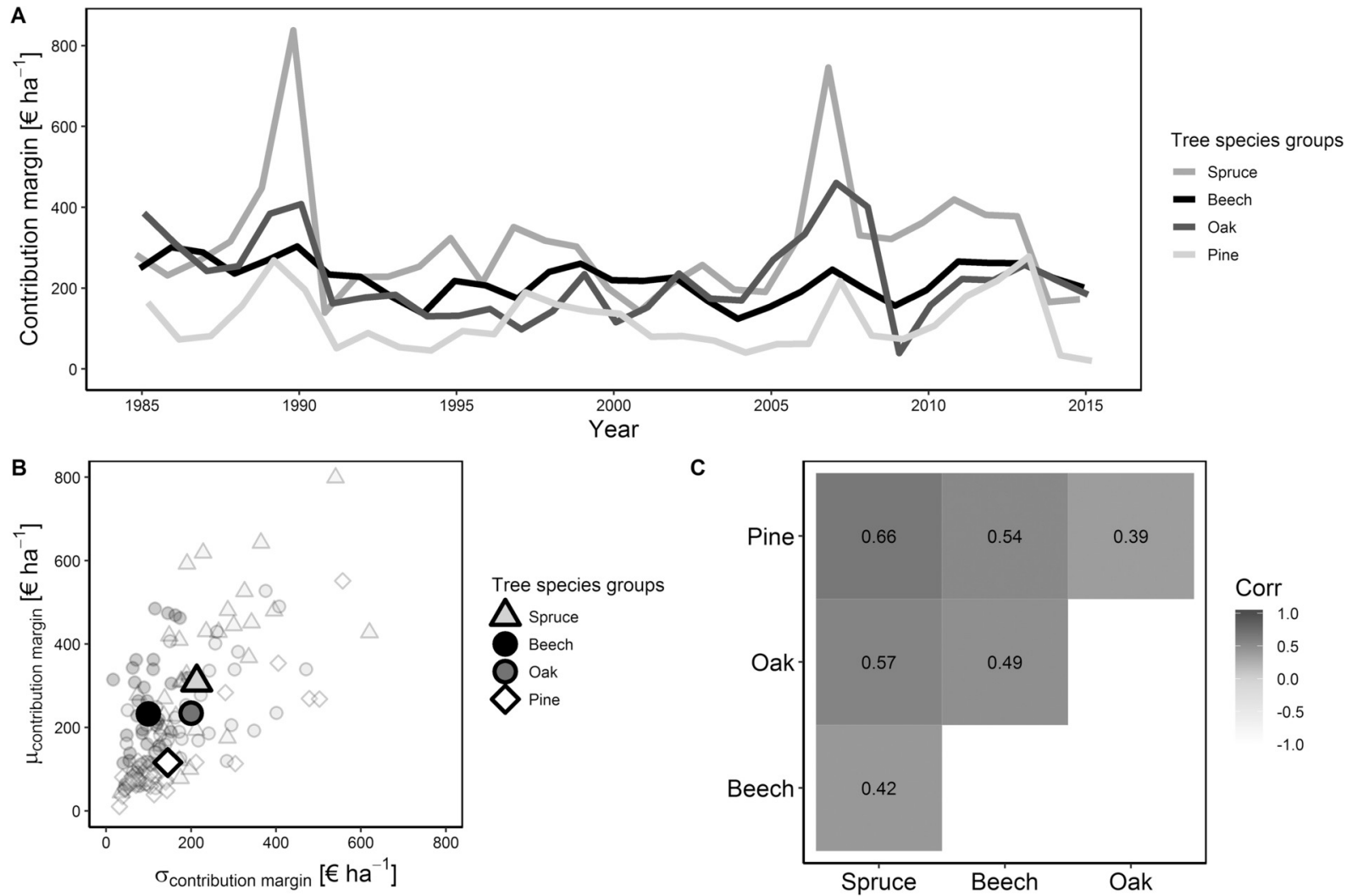

Fig. 6. (A) Detrended mean development of the annual contribution margins ( $€ /$ ha) of the tree species groups of the forest enterprises. (B) Mean $(\mu)$ vs. deviation ( $\sigma)$ distribution of the detrended annual CM I of the tree species groups of the forest enterprises individually (small points) and grouped by tree species group (large points). (C) Matrix showing the correlation coefficients between the detrended CMs I of the tree species groups.

The following describes our application of empirical data to the theoretical approach of the diversification effect. Beginning with a description of the data used and proceeding with the final results of our analysis, which are structured according to our theoretical framework.

\section{Empirical application}

\subsection{Materials}

\subsubsection{The forest accountancy data network Westfalen-Lippe}

The FAN Westfalen-Lippe is a cooperation project by the federal state of North Rhine-Westphalia, the Landesbetrieb Wald u. Holz NRW, the Forest Farmers Association NRW and the University of Göttingen. The network was founded in 1969, making it the oldest and most extensive compilation of private forest accounting data in Germany. It currently comprises around 37 middle-sized forest enterprises in North Rhine-Westphalia and bordering areas of Hesse and Lower-Saxony. Ever since its establishment the network has collected key economic indicators and tracked the growing timber stock of the participating forest enterprises. Most of the enterprises deliver annual reports to the network, which results in a nearly gapless set of data, making long-term comparisons possible. The average size of the enterprises is 1600 ha. Differences amongst enterprises are taken into account as the FAN is divided into different groups referred to as consultancy circles. These groups are categorized by the enterprises' dominant tree species group, which is either spruce, hardwood species or pine. Long-term developments in management and adaptation strategies of these groups can be derived from the collected data. These valuable time series can support decision-making processes for private forest landowners and provide tools for forest policy (Dög et al., 2018). As of 1985, the FAN provides data for the four main tree species groups Norway spruce (Picea abies L. Karst), European beech (Fagus sylvatica L.), oak (Quercus spec.) and Scots pine (Pinus sylvestris L.) in terms of their respective forest land area and economic performance. As a measure of return, we use the contribution margin I (CM I), which includes the revenues than can be ascribed to timber sales (of a whole enterprise and of each tree species group separately) minus the direct harvesting costs of timber (not including administrative costs). In our analysis, nominal financial figures have been adjusted for inflation by applying the annual percentage change of the German consumer price index (Statistisches Bundesamt, 2019) to derive real values.

\subsection{Data analysis and findings}

Our analysis aims to provide empirical verification and quantification of the diversification effect of tree species diversity in the forest enterprises of the FAN Westfalen-Lippe. We also intend to show whether our data meets the assumptions behind the theory of the diversification effect. In this context we analyze how adjusting our data to match the theory's premises can affect the way we interpret the effect of tree species diversification.

The empirical analysis is structured according to the previous theoretical framework in terms of a top-down analysis, beginning with the economics at the forest-enterprise-portfolio level, down to the individual and correlated performance of the single tree-species-assets. We then connected both perspectives to derive and empirically show the diversification effect in the forest enterprises. In the last step we measured the amount of risk reduced in the forest enterprises to quantify the effect of tree species diversity.

\subsubsection{Risk/return of forest enterprise portfolios}

In order to determine the economic performance of timber production in terms of risk and return, the annual contribution margins (CM I) were calculated for each forest-enterprise-portfolio. Fig. 1 shows 


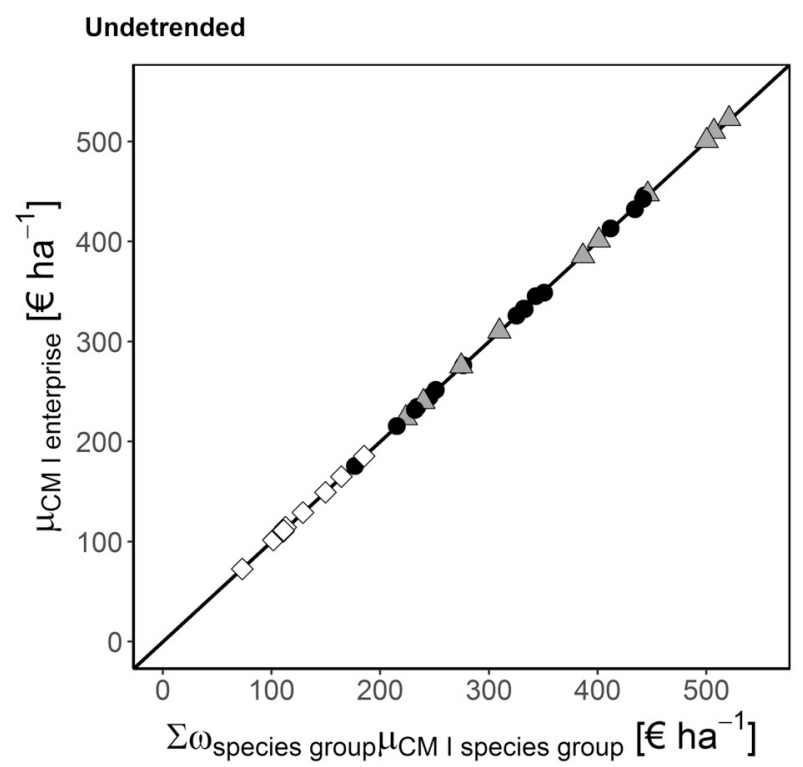

Detrended

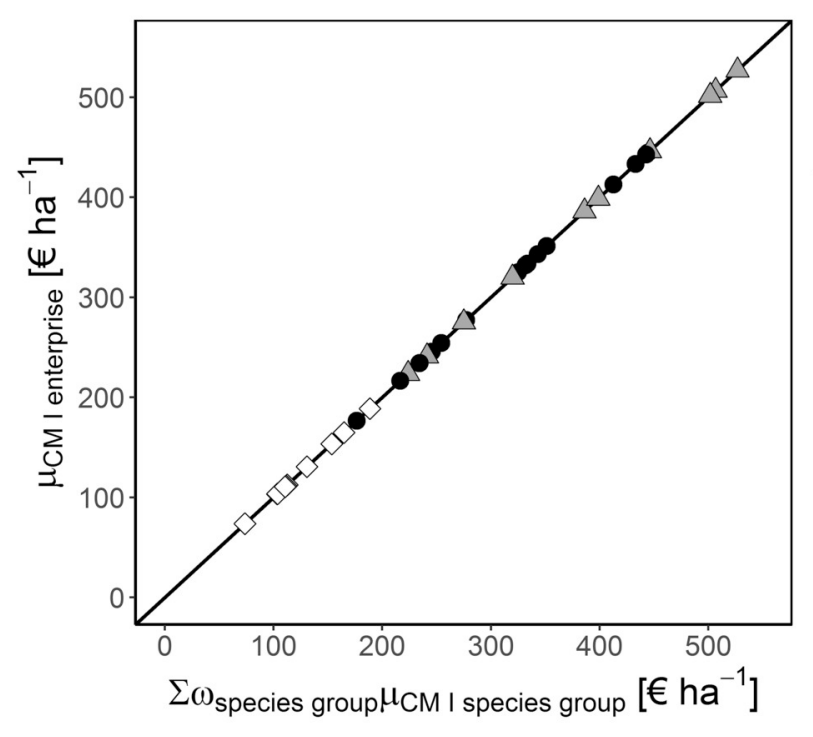

Consultancy circle $\triangle$ Spruce

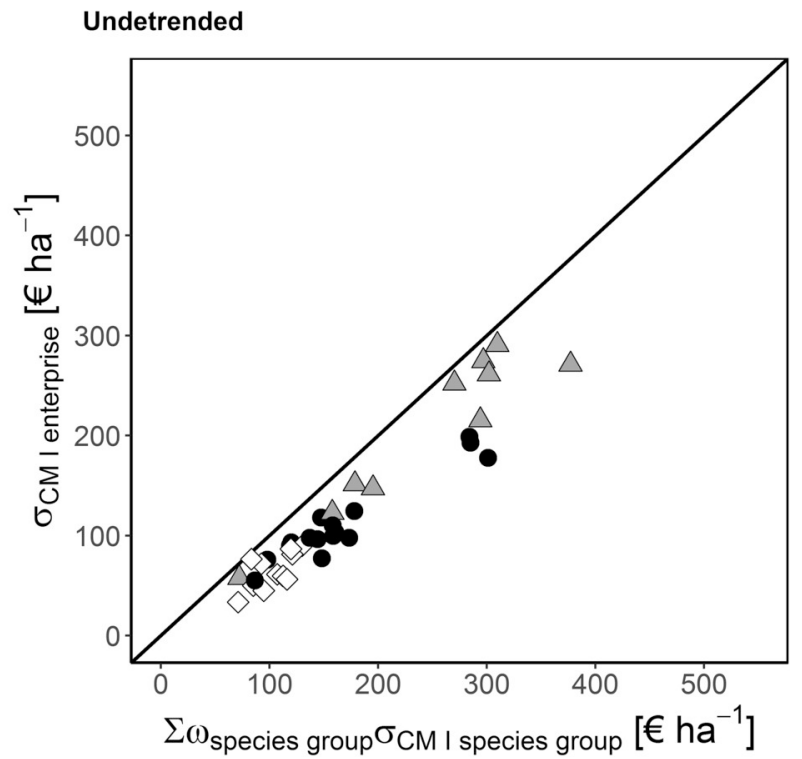

Detrended

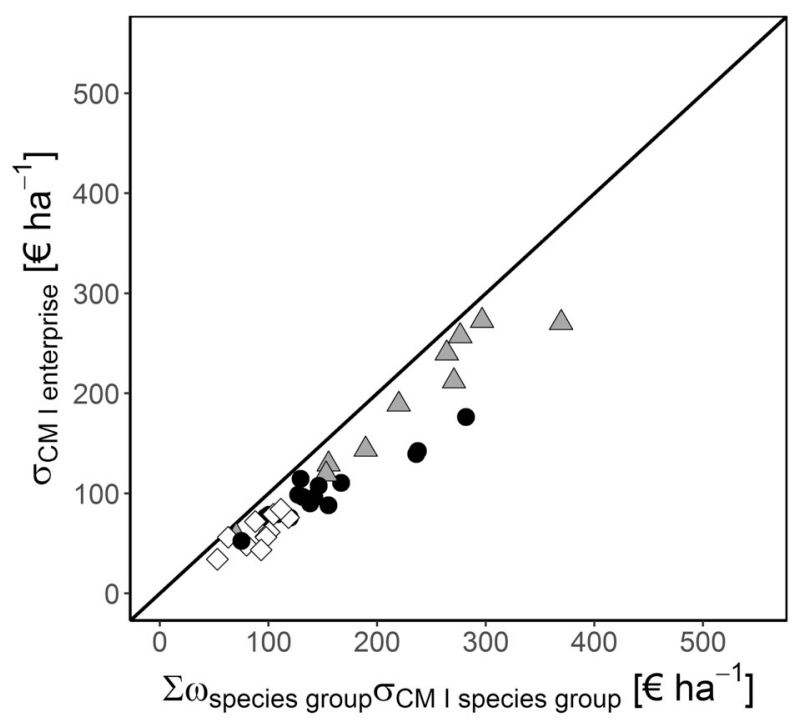

Hardwood $\diamond$ Pine

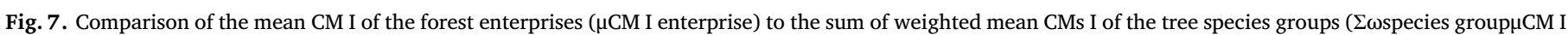

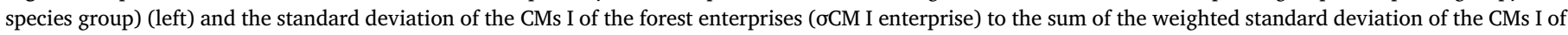
the tree species groups ( $\Sigma \omega$ species groupoCM I species group) (right).

the range of the annual contribution margins (CM I) of the forest enterprises (ha) over a time span of 30 years for each consultancy circle. The development of the mean annual CM I per consultancy circle is visualized by the bold print lines.

It becomes apparent that that the spruce enterprises generated the highest mean annual contribution margins (overall $\mu=389 € /$ ha) followed by the hardwood enterprises (overall $\mu=310 € /$ ha) and lastly the pine enterprises (overall $\mu=123 € /$ ha). Fig. 1 also implies, that the spruce enterprises experienced the highest volatility (standard deviation) of the contribution margin (overall $\sigma=211 € /$ ha), followed by the hardwood enterprises (overall $\sigma=112 € /$ ha) and the pine enterprises (overall $\sigma=65 € / \mathrm{ha}$ ). This indicated correlation between the height of the contribution margin and its volatility becomes clear when the deviations are plotted over the mean return (Fig. 2). It becomes apparent how the mean return relates to deviation. Fig. 2 displays the empirical observable expression of the tradeoff between risk and return.

Fig. 2 shows that the risk-return spectrum varied considerably between forest enterprises and consultancy circles. The volatility of the contribution margin shows a clear increasing trend over the mean contribution margin with a distinct disparity between the consultancy circles.

The results illustrated in Figs. 1 and 2 highlight the differences between the forest enterprises regarding the economic performance attributed to timber production over time. While some forest enterprises generated high returns and experienced high return volatility, other enterprises generated lower returns with lower return volatility. One of the aims of this study was to show how the performance of the economic return of the forest-enterprise-portfolios was linked to their tree-species-asset diversity. The following will illustrate the connection between return and risk in forest enterprises and diversity of the growing stock.

\subsubsection{Risk/return vs. tree species group diversity}

In order to examine the relationship between the economic 

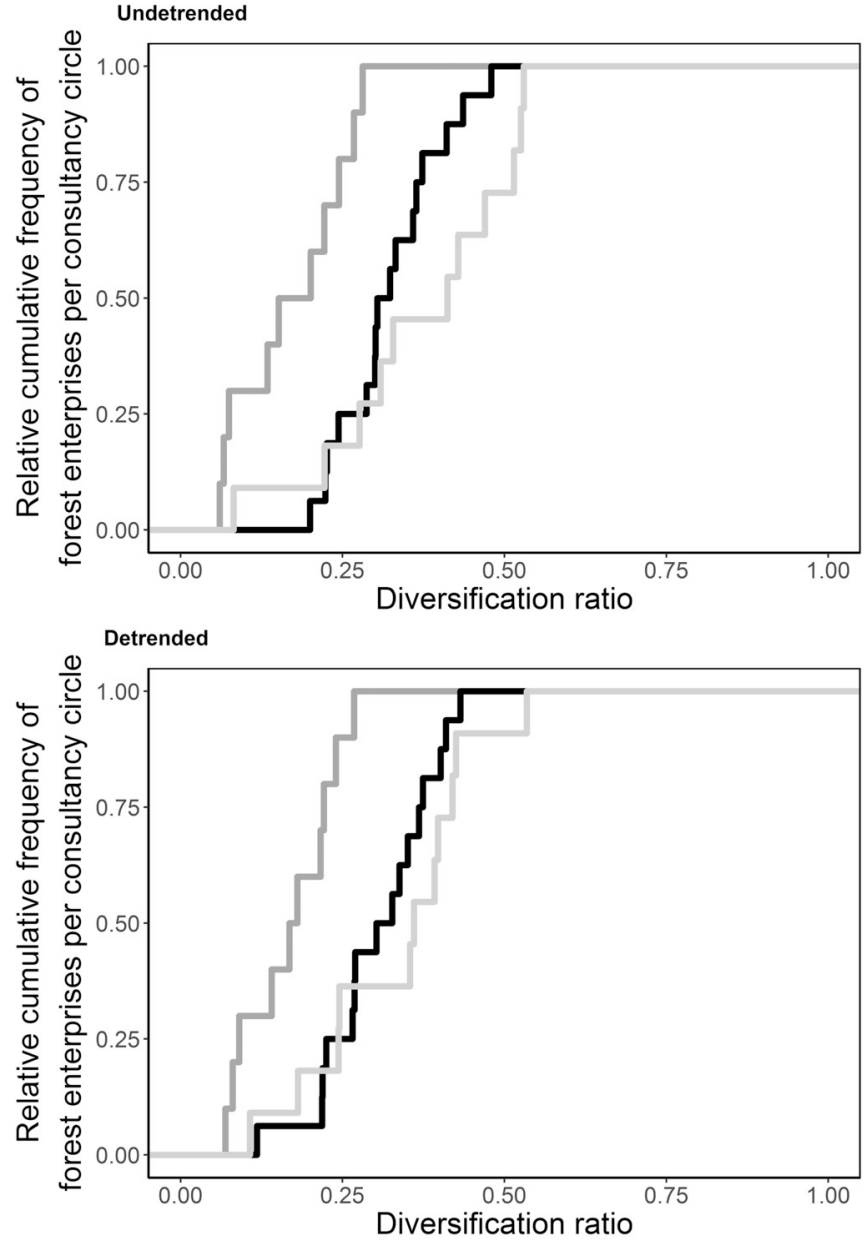

Consultancy circle - Spruce - Hardwood - Pine

Fig. 8. Cumulative distribution of the forest enterprises per consultancy circle based on the amount of risk reduction or size of the diversification effect for both the undetrended and detrended data.

performance of the forest enterprises and the composition of the growing stock, the standardized tree species group diversity was calculated for each forest enterprise according to Eq. (2). The result was paired with the results of Figs. 1 and 2. Fig. 3 illustrates the return and risk versus the evenness of distribution of the tree species groups in the forest enterprises.

Fig. 3 shows the dependency of return (left) and the dependency of risk (right) on the standardized tree species group evenness $E$ (Eq. (2)). It becomes apparent, that with an increased even distribution of the tree species groups in a forest enterprise (evenness $\rightarrow 1$ ), both the height of the expected contribution margin as well as the volatility of the contribution margin are decreasing. Fig. 3 illustrates how the differences between the forest enterprises in terms of their economic performance was reflected in the differences between the enterprises in regard to the diversity of their underlying tree species.

\subsubsection{Risk/return of tree species areas}

The previous results indicate that a driving factor for the economic performance of the forest enterprises lies in the composition of the tree species groups. This calls for shifting the perspective from the forestenterprise-portfolio level to individual tree-species-assets. Fig. 4 (A) shows the development of the mean annual contribution margin (CM I) of all forest enterprises per tree species group area (ha) over a time span of 30 years.

Fig. 4 (A) shows, that the spruce generated the highest annual contribution margins (overall $\mu=309 € /$ ha), followed by the oak (overall $\mu=234 € /$ ha), the beech (overall $\mu=232 € /$ ha) and lastly the pine (overall $\mu=116 € /$ ha). This is also expressed in Fig. 4 (B) showing the mean contribution margins per tree species group vs. their mean standard deviation for each enterprise. The graph shows, that the spruce exhibited the highest volatility of the contribution margin (overall $\sigma=225 € /$ ha), followed by oak (overall $\sigma=218 € /$ ha), the pine (overall $\sigma=154 € /$ ha) and lastly the beech (overall $\sigma=118 € /$ ha). Fig. 4 (B) displays the empirical observable expression of the tradeoff between risk and return in tree species groups. Fig. 4 (C) also shows the correlation coefficient $\rho$ of the contribution margins of the individual tree species groups. It becomes apparent that the tree species returns were all positively correlated but not perfectly correlated over the time span of 30 years. These correlation coefficients between the contribution margins of the tree species groups indicate the empirical diversification effect.

However, considering the premise of stationarity of time series Fig. 4 (A) indicates that the annual contribution margins of the tree species groups were not stationary over time. This leads to spurious correlations between the tree species assets as their correlations could be influenced by uptrends and downtrends. Therefore, each contribution margin time series of each enterprise and tree species group was checked for stationarity using the Augmented Dickey-Fuller test (ADF) and Kwiatkowski-Phillips-Schmidt-Shin (KPSS). In the cases were stationarity was not fulfilled and a trend was observe, we fitted a linear model to the time series and removed the trend subsequently. The summarized results can be seen in Fig. 5 .

Fig. 5 shows that the spruce experienced an uptrend, while the beech and the oak a downtrend. The pine was already stationary to begin with and required only a minor trend adjustment. After detrending we receive new values as we generated a new time series as seen in Fig. 6 (A).

Fig. 6 (B) shows the mean contribution margins per tree species group vs. their mean standard deviation for each enterprise after the time series were detrended. While the overall mean contribution margins stayed the same, the volatility of the contribution margin slightly decreased (overall $\sigma=$ spruce $213 € /$ ha; oak $200 € /$ ha; pine $145 € /$ ha; beech $99 € /$ ha). Fig. 6 (C) shows that after detrending the data new correlations could be observed. Overall all the tree species groups now showed higher positive correlations. Particularly spruce and beech but also spruce and oak now had stronger positive correlations. These findings support the high uncertainty associated with return correlations. More closely correlated tree species assets indicates that the diversification effect will be lower compared to the undetrended data.

\subsubsection{Diversification effect}

In regard to the diversification effect, Fig. 7 shows that the mean contribution margins of the forest enterprises were equal to the weighted sum of the mean contribution margins of the underlying tree species groups in the forest enterprises (left). This illustrates the linear combination of return of the tree-species-assets in terms of Eq. (4). On the other hand, the standard deviation of the forest-enterprise-portfolios was lower than the weighted sum of the standard deviations of the underlying tree species groups in the forest enterprises (right). It illustrates that the combined risk of the tree species as part of a forestenterprise-portfolio is lower than the individual tree-species-assets risk. Fig. 7 (right) exhibits the non-linear combination of risk in terms of Eq. (3) for both the undetrended and detrended time series.

Fig. 7 illustrates the empirical evidence that shows a positive diversification effect, as the return volatility of the tree-species-assets was reduced in the forest-enterprise-portfolio, while their annual mean return remained the same. Only a slight difference between the undetrended and detrended data was observed.

Looking at the ratio between individual asset risk and portfolio risk allowed to quantify the amount of risk reduction in a forest-enterpriseportfolio in terms of Eq. (5). The diversification ratio quantifies the amount of reduced risk within the forest enterprise portfolios for both 
the undetrended and detrended times series as seen in Fig. 8.

On average, the strongest effects of risk reduction were observed in the pine enterprises (37\%), followed by the hardwood enterprises (32\%) and the spruce enterprises (17\%) (Fig. 8). After detrending the diversification ratios slightly decreased (pine 33\%; hardwood $30 \%$; spruce $16 \%$ ).

\section{Discussion and conclusion}

Our study's objective was to provide empirical verification and quantification of the diversification effect and to analyze the applicability of empirical FAN data to the theoretical model particularly in regard to the premise of stationarity of time series.

The data of the FAN Westfalen-Lippe provides empirical evidence for a positive diversification effect associated with a diversified tree species portfolio in all forest enterprises. The strongest diversification effects (diversification ratios in Fig. 8) were observed in the forest enterprises with the highest standardized tree species group diversity (evenness $E$ in Fig. 3). However, enterprises with evenly distributed species groups also generated the lowest contribution margins. The more diversified a forests enterprise was, the more it benefited from the diversification effect. At the same time, it generated the lowest economic returns. The highest returns and absolute volatility were generated by the spruce enterprises (Fig. 2), as the spruce species also generated the highest returns and standard deviation (Fig. 4, B). An increasing share of hardwood species and pine, resulted in lower returns, while stronger diversification effects occurred due to a higher interface of imperfectly correlated tree species groups. Ultimately, the highest diversification effects were observed in the pine enterprises, where the pine species produced the least amount of return and standard deviation.

Apart from showing the diversification effect empirically, we wanted to show whether or not our data was consistent with theory, particularly in regard to stationarity of our time series data. Fig. 5 showed that the mean contribution margin time series of the tree species groups were not stationary over time. As seen in Fig. 5 on average the spruce developed an uptrend while the beech and oak developed a downtrend in the contribution margins. Looking at the individual time series of each forest enterprise and tree species group, we were able to identify where these trends came from and subsequently detrended the data where necessary. After detrending the time series (Fig. 5) the data now showed consistency with the theory's stationarity assumption. While detrending did not change the overall mean height of the species' contribution margins, it did have a small impact on their standard deviations, which decreased slightly. More importantly however, detrending resulted in different correlations between the tree species assets (compare Fig. 4, C and Fig. 6, C). After detrending the time series, there was generally a stronger positive correlation between tree species returns. Particularly the conifer species were now more closely correlated with the broadleaf species. These stronger positive correlations ultimately resulted in weaker diversification effects as compared to the undetrended data (Fig. 8).

While detrending our data did not impact the outcome of our analysis significantly in terms of the observed diversification effect, detrending data can impact the way we interpret the performance of tree species assets in regard to optimizing the diversification effect.

In the context of modern portfolio theory (MPT), literature suggests optimizing the diversification effect by finding specific management strategies (see e.g. Knoke et al., 2008; Neuner et al., 2013). However (as these studies also point out), due to the limitations of MPI it does not allow to derive specific recommendations for management. Our analysis draws the same conclusion. By removing the obvious trends in our data and therefore ignoring the existence of downtrends and uptrends, we run the risk of making false conclusions when it comes to evaluating the economic performance of the tree species. Even though detrending our data resulted in more accurate correlations between tree-species- assets, we also assumed that these correlations will remain constant over time. This may lead to a too positive interpretation of the diversification effect, as it could suggest to include assets with a long-term downtrend, as long as the portfolio includes a second asset, which is not perfectly correlated with that asset. While this is a general problem of the diversification effect and portfolio theory, the issue is particularly relevant in the forestry context. Systematic risks such as slow moving trends caused by shifting demands of the timber industry or climate change may not get noticed or are not accounted for due the model's assumptions.

Apart from the theoretical assumption on the stationary behavior of risk, the model also defines how risk is quantified. Quantifying risk is only useful to the degree that it reflects the investors' subjective concerns. Using standard deviation means evaluating risk symmetrically in terms of upside and downside deviations. In forestry, downside deviations may occur due to calamities, dropping timber prices or market saturation. In all cases, downside deviation is not desired. Upside deviations can occur due to salvage logging, but also due to rising timber prices. So upside deviations are sometimes desired. Furthermore, the weighting of upside and downside risks can vary depending on risk aversion (Koellner and Schmitz, 2006). Whether or not it is appropriate to evaluate risk symmetrically is thoroughly discussed and the use of alternative measures of risk, such as semi-variance, lower partial moments or value at risk, requires further supportive research (see Matthies et al., 2019).

\subsection{Concluding remarks}

Managing the diversification effect means managing the correlation between portfolio assets. For a forest enterprise this means managing biological production (i.e. tree species selection) and technical production (i.e. harvested amount of timber). Decisions in biological production are long-term, mostly irreversible and depend on very specific climate and site conditions and are limited to the size of the forest enterprise (Möhring, 2010). Technical production ultimately depends on the success of biological production and is linked to specific short and mid-term objectives of a forest enterprise. Considering the fundamental differences between the forest enterprises of the FAN in terms of biological and technical production, there would be no benefit in finding specific management strategies based on general assumptions. Therefore, the study covers - but is limited to - the universal element of portfolio theory, which is the mere effect of diversification.

There is no question that previous studies applying the concept of the diversification effect have made significant contributions regarding the possibilities in analyzing the diversification effect to optimize timber production. However, it appears that the model's popularity is not due to its empirical soundness as it is based on several premises (Clasen et al., 2011). While our analysis confirms this, our pure empirical application to a very theoretical concept, allowed us to determine the extent to which practice can be explained by theory. Our data shows that the diversification effect exists and is measurable. We cannot know, however, whether or not the effect is efficient because the model predefines and interprets risk for us. Thus, the efficiency of the diversification effect can only be determined if specific risk-return preferences are known and if non-stationary behavior of assets is accounted for.

For the first time our analysis reconstructed the empirical strategies of forest enterprises regarding tree species diversity. This approach can be an important contribution to align political incentives, which support diversification strategies and can provide an initial impulse required for decision makers in forestry to develop customized diversification strategies. After all, forest accountancy data networks collect data to give enterprises the opportunity to compare their operational success to one another. On top of the network's conventional scoring system, additional analyses such as these provide valuable insights for both theory and practice and strengthen scientific and practical 
collaboration.

\section{Acknowledgements}

We would like to thank Prof. Dr. Carola Paul, Dr. Kai Husmann and Jan Schick (M.Sc.) for helpful corrections and comments improving the quality of our manuscript. We also thank the reviewers for their helpful suggestions.

\section{Funding}

This research did not receive any specific grant from funding agencies in the public, commercial, or not-for-profit sectors.

\section{Declaration of Competing Interest}

None.

\section{References}

Beinhofer, B., 2009. Zur Anwendung der Portfoliotheorie in der Forstwissenschaft; Finanzielle Optimierungsansätze zur Bewertung von Diversifikationseffekten. Dissertation. Wissenschaftszentrum Weihenstephan für Ernährung, Landnut-zung und Umwelt, TUM.

Brockwell, P.J., Davis, R.A., 2016. Stationary processes. In: Brockwell, P.J., Davis, R.A. (Eds.), Introduction to Time Series and Forecasting. vol. 21. Springer, Cham, pp. 39-71.

Brunette, M., Dragicevic, A., Lenglet, J., Niedzwiedz, A., Badeau, V., Dupouey, J.-L., 2014. Portfolio Management of Mixed-Species Forests: Portfolio Management of Mixed-Species Forests. [University works] auto-saisine.

Cheng, P., Roulac, S.E., 2007. Measuring the effectiveness of geographical diversification. J. Real Estate Portfolio Manag. 13 (1), 29-44.

Choueifaty, Y., Coignard, Y., 2008. Toward maximum diversification. JPM 35 (1), 40-51. https://doi.org/10.3905/JPM.2008.35.1.40.

Clasen, C., Griess, V.C., Knoke, T., 2011. Financial consequences of losing admixed tree species: a new approach to value increased financial risks by ungulate browsing. Forest Policy Econ. 13 (6), 503-511. https://doi.org/10.1016/j.forpol.2011.05.005

Dög, M., Wildberg, J., Möhring, B., 2018. Analysis of a long-term forest accountancy network to support management and controlling. Open Agricult. 3 (1), 155-162. https://doi.org/10.1515/opag-2018-0016.

Dragicevic, A., Lobianco, A., Leblois, A., 2016. Forest planning and productivity-risk trade-off through the Markowitz mean-variance model. Forest Policy Econ. 64, 25-34. https://doi.org/10.1016/j.forpol.2015.12.010.

Figge, F., 2004. Bio-folio: applying portfolio theory to biodiversity: bio-folio: applying portfolio theory to biodiversity. Biodivers. Conserv. 13, 827-849.

Gamfeldt, L., Snäll, T., Bagchi, R., Jonsson, M., Gustafsson, L., Kjellander, P., Ruiz-Jaen, M.C., Fröberg, M., Stendahl, J., Philipson, C.D., Mikusiński, G., Andersson, E., Westerlund, B., Andrén, H., Moberg, F., Moen, J., Bengtsson, J., 2013. Higher levels of multiple ecosystem services are found in forests with more tree species. Nat. Commun. 4, 1340. https://doi.org/10.1038/ncomms2328.

Gibson, R.C., 1990. Asset Allocation: Balancing Financial Risk, 3rd ed. XV Dow JonesIrwin, Homewood Ill (267 S).

Hight, G.N., 2010. Diversification effect: isolating the effect of correlation on portfolio risk. J. Financ. Plan. 23 (5), 54-61.
Knoke, T., 2008. Mixed forests and finance - methodological approaches. Ecol. Econ. 65 (3), 590-601. https://doi.org/10.1016/j.ecolecon.2007.08.009.

Knoke, T., 2012. Forstbetriebsplanung: Als Entscheidungshilfe. Ulmer, Stuttgart, XII (408 S)

Knoke, T., Wurm, J., 2006. Mixed forests and a flexible harvest policy: a problem for conventional risk analysis? Eur. J. For. Res. 125 (3), 303-315. https://doi.org/10 1007/s10342-006-0119-5.

Knoke, T., Stimm, B., Ammer, C., Moog, M., 2005. Mixed forests reconsidered: a forest economics contribution on an ecological concept. For. Ecol. Manag. 213 (1-3), 102-116. https://doi.org/10.1016/j.foreco.2005.03.043.

Knoke, T., Ammer, C., Stimm, B., Mosandl, R., 2008. Admixing broadleaved to coniferous tree species: a review on yield, ecological stability and economics. Eur. J. For. Res. 127 (2), 89-101. https://doi.org/10.1007/s10342-007-0186-2.

Knoke, T., Messerer, K., Paul, C., 2017. The role of economic diversification in forest ecosystem management. Curr. For. Rep. 3 (2), 93-106. https://doi.org/10.1007/ s40725-017-0054-3.

Koellner, T., Schmitz, O.J., 2006. Biodiversity, ecosystem function, and investment risk. BioScience 56 (12), 977. https://doi.org/10.1641/0006-3568(2006)56[977:BEFAIR] 2.0.CO;2.

Markowitz, H., 1952. Portfolio selection. J. Fin. 7 (1), 77-91.

Marutani, T., 2010. The effect of site quality on economically optimal stand management. JFE 16 (1), 35-46. https://doi.org/10.1016/j.jfe.2009.05.001.

Matthies, B.D., Jacobsen, J.B., Knoke, T., Paul, C., Valsta, L., 2019. Utilising portfolio theory in environmental research - new perspectives and considerations. J. Environ. Manag. 231, 926-939. https://doi.org/10.1016/j.jenvman.2018.10.049.

Möhring, B., 2010. Optimierung forstlicher Produktion unter Beachtung von finanziellen Restriktionen | optimisation of forest production under financial restrictions. Swiss For. J. 161 (9), 346-354. https://doi.org/10.3188/szf.2010.0346.

Möhring, B., Burkhardt, T., Gutsche, C., Gerst, J., 2011. Berücksichtigung von Überlebensrisiken in den Modellen der Waldbewertung und der forstlichen Entscheidungsfindung. Allg. Forst Jagdztg 182 (7/8), 160-171.

Möhring, B., Wilhelm, S., Dög, M., 2018. The relevance of economic data from forest accountancy networks for forest management, research and politics consultation. Small Scale For. 17 (1), 25-40. https://doi.org/10.1007/s11842-017-9373-2.

Neuner, S., Beinhofer, B., Knoke, T., 2013. The optimal tree species composition for a private forest enterprise - applying the theory of portfolio selection. Scand. J. For. Res. 28 (1), 38-48. https://doi.org/10.1080/02827581.2012.683038.

Neuner, S., Albrecht, A., Cullmann, D., Engels, F., Griess, V.C., Hahn, W.A., Hanewinkel, M., Härtl, F., Kölling, C., Staupendahl, K., Knoke, T., 2015. Survival of Norway spruce remains higher in mixed stands under a dryer and warmer climate. Glob. Chang. Biol. 21 (2), 935-946. https://doi.org/10.1111/gcb.12751.

Önal, H., 1997. Trade-off between structural diversity and economic objectives in forest management. Am. J. Agric. Econ. 1001-1012.

Perold, A.F., 2004. The capital asset pricing model. J. Econ. Perspect. 18 (3), 3-24. https://doi.org/10.1257/0895330042162340.

Pretzsch, H., 2009. Forest Dynamics, Growth and Yield: From Measurement to Model. Springer, Berlin (664 pp.).

Roessiger, J., Griess, V.C., Härtl, F., Clasen, C., Knoke, T., 2013. How economic performance of a stand increases due to decreased failure risk associated with the admixing of species. Ecol. Model. 255, 58-69. https://doi.org/10.1016/j.ecolmodel.2013.01. 019.

Shannon, C.E., Weaver, W., 1949. The Mathematical Theory of Communication, 14th ed. (125 S).

Sharpe, W.F., 1964. Capital asset prices: a theory of market equilibrium under conditions of risk. J. Financ. 19 (3), 425. https://doi.org/10.2307/2977928.

Speidel, G., 1967. Forstliche Betriebswirtschaftslehre: Eine Einführung. Parey, Hamburg u.a (289 S).

Statistisches Bundesamt, 2019. Verbraucherpreisindizes für Deutschland: Lange Reihen ab 1948. 


\section{Study 3}

Title: Liquiditätssicherung privater Forstbetriebe bei Kalamität

Authors: Gundula von Arnim, Johannes Wildberg, Bernhard Möhring

Published in: Holz-Zentralblatt

Year: 2020

Author contribution: The authors Gundula von Arnim, Johannes Wildberg and Bernhard Möhring were involved in publishing this study. The study was written by Gundula von Arnim with the support of Johannes Wildberg and was supervised by Bernhard Möhring. 


\section{Liquiditätssicherung privater Forstbetriebe bei Kalamität}

Finanzierungsmodelle stoßen an ihre Grenzen

Von Gundula von Arnim¹, Johannes Wildberg² und Bernhard Möhring ${ }^{3}$

Die Hauptfinanzierungsart von privaten Forstbetrieben ist die Form der Selbst- oder Umschichtungsfinanzierung durch den Erlös verkauften Holzes. Dies entspricht nach Auswertung der Daten des Forstbetriebsvergleiches Westfalen-Lippe einem Anteil von etwa $80 \%$ aller Einnahmen. Die kalamitätsbedingen Ausfälle von Holzerlösen der letzten beiden Jahre und die Fortsetzung dieser in diesem Jahr zeigen, dass diese Art der Finanzierung an ihre Grenzen stößt. Da bisher das Thema Finanzierung in privaten Forstbetrieben bei Kalamität in der forstwissenschaftlichen Forschung wenig differenziert betrachtet blieb, wurde das Thema im Rahmen einer Masterarbeit an der Abteilung Forstökonomie der Georg-August-Universität in Göttingen unter der Leitung von Prof. Bernhard Möhring aufgearbeitet.

$\mathrm{H}$

erzu wurde in Zusammenarbeit mit dem Waldbauernverand der land- Nordrhein-Westfalen und der land- und forstwirtschaftlichen Unternehmensberatung BB Göttingen 2020 eine explorative Feldstudie durchgeführt und ausgewertet. Insgesam geführt und ausgewertet. Insgesamt beendete Online-Fragebögen von privaten Forstbetrieben mit einer durchten Forstbetrieben mit einer durchner Gesamtfläche von über 210000 ha ausgewertet.

Um das Finanzierungsverhalten privater Forstbetriebe vor dem Hintergrund der aktuellen Kalamität detail-

1) M. Sc. Gundula von Arnim ist wissenschaftliche Mitarbeiterin an der Abteilung nür Forstökonomie und nachhaltige Landversität Göttingen.

${ }^{2)} \mathrm{M}$. Sc. Johannes Wildberg ist wissenschaftlicher Mitarbeiter an der Abteilung für. Forstökonomie der Georg-August3) Universitât Gottingen.

Prof. Dr. B. Möhring, ist Leiter der Abgust-Universität Göttingen.

lierter zu analysieren, wurden betriebliche Maßnahmen und forstpolitische Instrumente zur Liquiditätssicherung unersucht und die steuerfreie Rücklag nach $\S 3$ des Forstschäden-Ausgleichsgesetzes (ForstSchAusglG) evaluiert. Zusammen mit dem Waldbauernver-

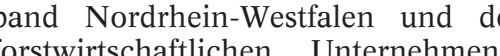
beratung BB Göttingen GmbH wurde knapp 400 Privatforstbetriebe über Online-Umfrageplattform Unipark zur Teilnahme an der Befragung eingeladen. Die Themenschwerpunkte umfassten die forstbetriebliche Ausstattung und Ausrichtung die Kalamitätsbetroffenheit in den Jahren 2018 und 2019, die steuerfreie Rücklage 18 un des ForstSchAusglG, und zuletzt betriebswirtschaftliche und forstpolitische Strategien zur Anpassung nach Kalamitätsereignissen. Die einzelnen Bereiche wurden anhand geschlossener Fragen mit Einfach- oder Meh fachnennung sowie offenen Fragen mit optionaler Eigennennung abgefragt. Dadurch, dass ein Anteil der FrageboDadurch, dass ein Anteil der Frageb gaben sich für die einzelnen Auswer-

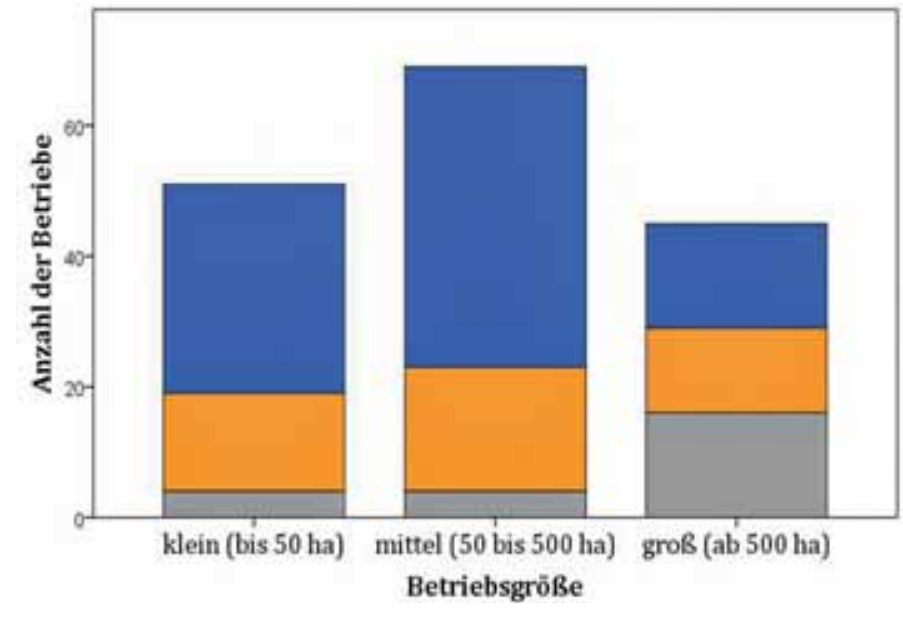

$\begin{array}{ll} & \begin{array}{l}\text { Die Auswertung der priorisierten Be- } \\ \text { triebsziele zeigt, dass bei der Bewirt- } \\ \text { schaftung vor allem der Vermögenser- }\end{array} \\ \text { GFiebstypen } & \text { halt und die Wertnachhaltigkeit für all }\end{array}$ Laubholz
Kiefer

Abbildung 1 Eigentümergrößenklassen der befragen Forstbetriebe $(n=221)$

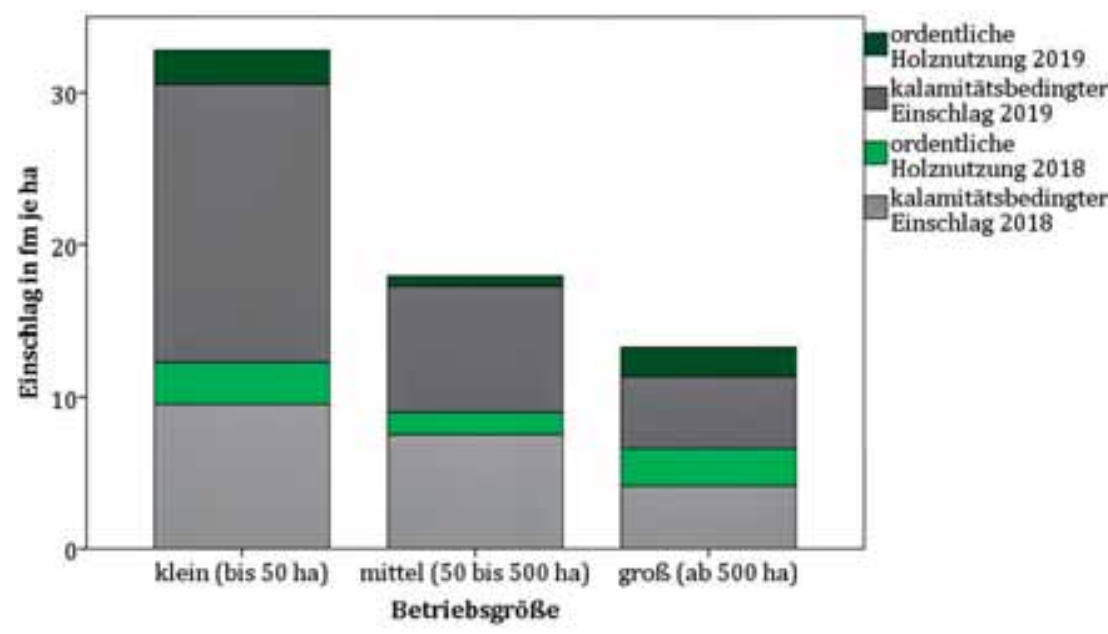

Abbildung 3 Durchschnittlicher Einschlag der Jahre 2018 und 2019 nach Eigentumsgrößenklassen sowie getrennt nach außerordentlicher und ordentlicher Holz nutzung $(n=167)$

*-klein *-mittel *-groß tungen zum Teil unterschiedliche Teilnehmerzahlen.

Rund 300 der eingangs 400 befragten orstbetriebe wurden zunächst anhand der Ausstattung der Baumartenanteile und der Betriebsgröße zusammengedie Betriebe nach ihrer Hauptbaumart in die Betriebstypen Fichten-, Laubholz- und Kiefernbetriebe klassifiziert. Zudem wurden die Betriebe anhand der Waldflächengröße in groß (ab 500 ha), mittel (50 bis 500 ha) und klein (bis 50 ha) eingeteilt (Abbildung 1).

\section{Betriebliche Zielsetzung} und Ausrichtung Betriebe wichtig ist. Insbesondere die großen und mittleren Forstbetriebe sind wirtschaftlich orientiert, während für kleine Betriebe die ökologischen und sozialen Ziele und die Versorgung mit Brennholz bedeutender sind (Abbildung 2).

\section{Kalamitätsbetroffenheit}

Im Wirtschaftsjahr 2018 betrug der kalamitätsbedingte Holzeinschlag im Mittel rund 77\%, im Jahr 2019 etwa betriebe durchschnittlich 9,3 die Forstha ein, im Jahr 2019 waren es etwa 11, $( \pm 1,6) \mathrm{Fm} / \mathrm{ha}$. Kleinere Forstbetriebe waren am stärksten betroffen. Die triebe mittlerer Größe zeigten in beiden Jahren die geringste ordentliche HolzJahren 2018 und 2019 die geringste Einschläge je Hektar (Abbildung 3)

Dieses im ersten Moment überraschende Ergebnis könnte darauf zurückzuführen sein, dass die von Kalamität betroffenen kleineren Betriebe eine höhere Bereitschaft zur Teilnahme an de fenen kleineren Betriebe Größer Betriebe zeigten generell eine hohe Bereitschaft zur Teilnahme, unabhängig von ihrer Betroffenheit von Kalamitäten. Dies spiegelt sich in Abbildung 3 in einem niedrigeren hektarbezogenen Einschlag für größere Betriebe wider, sich der kalamitätsbedingte Holzeinschlag auf einer größeren Fläche verteilt. nutzung je Hektar auf Im Vergleich hatten die großen Forstbetriebe in den Befragung hatten als die weniger betrof-
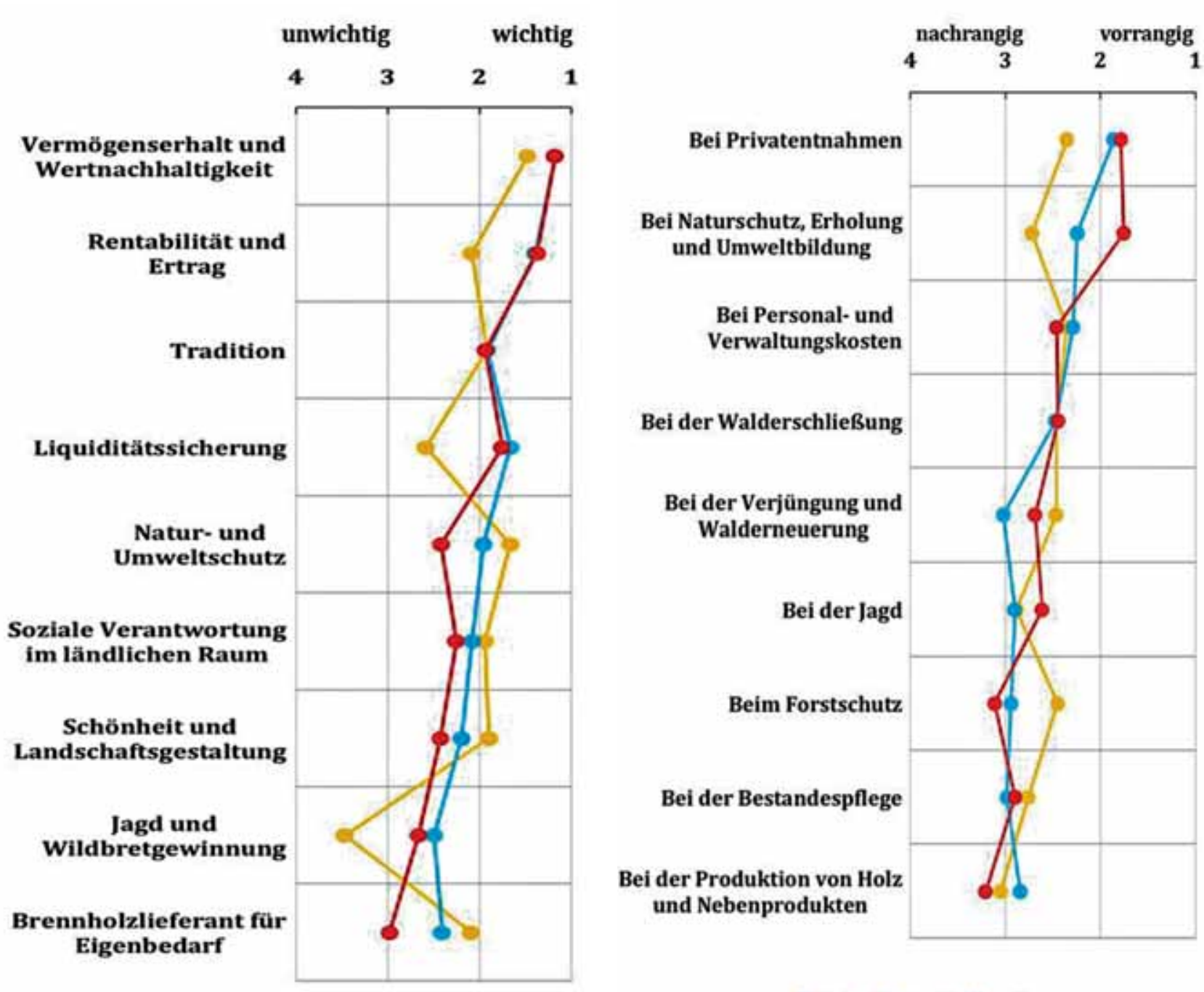

Abbildung 2 Rangordnung der Betriebsziele nach Betriebsgroßße, bei $\mathrm{n}=160$, davon 47 kleine (bis $50 \mathrm{ha}$ ), 70 mitte( 500 ha) und 43 große (über 500 ha) Forstbe-

Die steuerfreie Rücklage nach $§ 3$ des ForstSchAusglG

Etwa $14 \%$ der befragten Forstbetriebe besitzen eine steuerfreie Rücklage. Dies sind vor allem große Forstbetriebe die die rechtlichen Vorgaben zur Buchführung erfüllen. Die derzeitige Höhe der Rücklagen beträgt bei ihnen durchschnittlich nur etwa 80 Euro/ha.

Etwa $42 \%$ der Forstbetriebe mit Rücklagen geben an, diese bisher nicht aufgelöst zu haben, obwohl bei einigen Forstbetrieben die Bildung der Rücklage mehr als zehn Jahre zurückliegt. Die restlichen $58 \%$ nennen als bisherigen Auflösungsanlass überwiegend Maßnahmen zur Wiederaufforstung, Nachge und die Beseitigung von Schäden We und die Beseitigung von Schäden Betriebsvorrichtungen. Die im Zusammenhang mit der ste erfreien Rücklage genannten Problem beziehen sich im Wesentlichen auf den bürokratischen Aufwand, die praktische Eignung und wirtschaftlichen Gegebenheiten der Betriebe.

Zahlreiche Betriebe nennen organisatorische Probleme bezüglich der Bildung der Rücklage. Der hohe Formalaufwand bei der Beantragung und Abrechnung, die für steuerliche Laien schwer verständlichen Formulare zeitliche Unmittelbarkeit der Verwendung und die fehlende Information werden hier als konkrete Schwierigkeit bezeichnet. Einige Betriebe schreiben, dass sie als nicht-buchführungspflichte Betriebe nicht zur Bildung einer Rücklage befähigt seien.

Neben den organisatorischen und betriebsspezifischen Voraussetzungen werden auch Probleme finanzieller Art aufgezählt. Mehrere Betriebe beschreiben, dass ihre aktuelle wirtschaftliche abwerfe, um eine Rücklage zu bilden. Die Rücklage sei nach „Kyrill“" im Jah 2007 für die Aufarbeitungskosten verwendet worden, und seitdem seien nicht genügend Einnahmen in den Betrieb zurückgeflossen. Auch wird kritisiert, dass die Höhe der Rücklage kaum dafür ausreiche, um die aktuellen Mindererlöse zu kompensieren und die notwendigen Maßnahmen durchzuführen. Mehrere Forstbetriebe argumentieren auch, dass sich diese Anlageform nicht rentiere, da durch die geringen Zinsen und die hohe und lange Bindung des Geldes enorm hohe Opportunitätskos-

\section{- klein $*$ mittel $\bullet$ groß}

Rangordnung der Maßnahmen zur Einspaße und 36 große Forstbetriebe). Ziffer 1
Z en in diesem Bereich werden vorrangig

ten entstünden und das Geld besser anderweitig genutzt werden könne. Zudem sei die Anlageform nicht mehr zeitgemäß und werde von den Banken kaum mehr angeboten. So sei die nicht attraktiver als die zweckgebundene Verwendung des Geldes.

Vorgeschlagene Verbesserungen der Regelung betreffen die Anlageform des Geldes. Auch der bürokratische Aufwand müsse gesenkt werden. Für eine größere Inanspruchnahme der Rücklagenbildung wird ebenso die Berücksichtigung von nicht-buchführenden Betrieben gefordert Zur Vereinfachung des Gesetzes solle der Nachweis zur betrieblichen Verwendung des Geldes vereinfacht werden. Der maximale Umfang der Rücklage müsse deutlich erhöht werden, um bei niedrigen Preisen trotzdem Liquiditätspuffer zu besitzen, und die Auflösungsgründe müssten erweitert werden.

\section{Anpassung nach Kalamität}

Nach der Vorgabe eines betrieblichen Kalamitäts-Szenarios bewerten die Forstbetriebe verschiedene Bereiche, in denen sie durch liquiditätssichernde Maßnahmen zur Überwindung der Kalamität und zum betrieblichen Überlenerseits auf eine Einsparung bei Ausgaben und andererseits auf eine Umsatzsteigerung ab. Außerdem wurden die Forstbetriebe um ihre Einschätzung von politischen Instrumenten zur Überwindung der Kalamität gebeten.

Bei der Auswertung der Antworten zur Ausgabeneinsparung nach Betriebsgröße wird deutlich, dass alle Betriebe vorrangig an Privatentnahmen sparen (Abbildung 4). Kleine Forstbetriebe bewerten das Potenzial zur Einsparung im Bereich von Forstschutzmaßnahmen und ebenfalls bei der Waldveriüngung und -erneuerung größer als mittlere und große Forstbetriebe. Große Forstbetriebe planen im Bereich Naturschutz, Erholung und Umweltbereich einzusparen. Auch auf Ausgaben im Zusammenhang mit der Jagd verzichten große Forstbetriebe eher als mittlere und kleine Forstbetriebe. Mittlere Forstbetriebe bewerten Ausgaben in der Waldveriüngung und -erneuerung sowie der Bestandespflege als unverzichtbar. Im Ge- 


\section{Liquiditätssicherung privater Forstbetriebe ...}

Fortsetzung von Seite 520

gensatz zu großen und kleinen Forstbetrieben bewerten sie die Produktion von Holz- und Nebenprodukten als eher verzichtbar.

Die Auswertung der Freitextfelder macht ersichtlich, dass die vorgeschlagenen Maßnahmen von einigen Betrieben bereits konkret umgesetzt wurden. Zum Beispiel gibt ein Betrieb an, am Personal in der Waldarbeit eingespart zu haben. Ein weiterer Betrieb konkretisierte, von der Einsparung in der nicht-kalamitätsbedingten Holzproduktion nur bei auskömmlichen Preisen abzusehen. Einige Forstbetriebe geben an, vor allem Fixkosten und ertragsunabhängige Kosten konsequent kürzen zu wollen.

Über alle Forstbetriebe zeigt sich, dass die Betriebe nach der Kalamität ih dass die Betriebe nach der Kalamitat ihin erster Linie neue Geschäftsfelder entwickeln oder ausbauen, zweitens die wickeln oder ausbauen, zweitens die betrieblichen Nebennutzungen intensi-
vieren und drittens mehr Fördergelder in Anspruch nehmen. Alle Forstbetriein Anspruch nehmen. Alle Forstbetrie-
be zeigen in der Bewertung auch, dass be zeigen in der Bewertung auch, dass
sie die Verpachtung der Eigenjagd, die Aufnahme von Fremdkapital und den Verkauf der Fläche vermeiden wollen. Die Auswertung der Antworten nach Betriebsgrößenklassen weist Unterschiede zwischen den Gruppen auf (Abbildung 5). Größere Forstbetriebe besitzen im Durchschnitt in allen Kategorien einen geringeren Mittelwert als mittlere und kleine Forstbetriebe. Das zeigt, dass große Forstbetriebe durch mehrere Maßnahmen eine Umsatzsteimehrere Maßnahmen eine Umsatzsteigerung erreichen möchten und dass die-
ses Ziel stärker als bei den anderen Betrieben ausgeprägt ist. Die wichtigste Maßnahme dieser Gruppe ist die UmMaßnahme dieser Gruppe ist die Um-
satzsteigerung durch die Entwicklung satzsteigerung durch die Entwicklung
oder den Ausbau neuer Geschäftsfelder. oder den Ausbau neuer Geschäftsfelder.
Mittlere Forstbetriebe streben hingegen Mittlere Forstbetriebe streben hingegen
eine größere Inanspruchnahme von Fördergeldern an. Kleine Forstbetrieb bewerten den Abbau des stehenden Holzvorrates als relativ wichtigste Maßnahme zur Umsatzsteigerung.

Das Profil aus Abbildung 5 verdeutlicht die Ablehnung mittlerer Forstbetriebe, zur Umsatzsteigerung den stehenden Holzvorrat abzubauen. Ebenso henden Holzvorrat abzubauen. Ebens zeigen kleine Forstbetriebe eine stärkere Ablehnung als mittlere und große
Forstbetriebe, Fremdkapital aufzunehmen.

Im Freitext ergänzten einige Forstbetriebe weitere Umsatz-Maßnahmen. Hierunter zählen neue Geschäftsfelder abseits der Forstbranche, wie Ausgleichs- und Ersatzmaßnahmen und Benutzungsprämien. Mehrere Forstbetriebe geben an, dass sie das forstwirtschaftliche Anlagevermögen verkaufe und die Branche verlassen möchten.

Der dritte Fragenblock zur Anpassung nach starker Kalamität befasst sich mit den möglichen politischen Instrumenten. Über alle Betriebe wird die $\mathrm{CO}_{2}$-Honorierung als dis wichtirste $\mathrm{CO}_{2}$-Honorierung als das wichtigste politische Instrument zur betrieblichen Anpassung nach Kalamität bewertet. An zweiter Stelle steht die Senkung de öffentlichen Abgaben, wie beispielswe se die Grundsteuer, Berufsgenossenschaftsbeitrag und Mitgliedsbeiträge in Boden- und Wasserverbänden. In Ab-
bildung 6 zeigt sich eine deutliche Auf- teilung bei der Wichtigkeit von staatlicher Betreuung zwischen den befürwortenden kleinen und den ablehnenden großen privaten Forstbetrieben. Die großen Forstbetriebe bewerten ebenfalls eine staatliche Waldschadensversicherung als „eher unwichtig“. Eine Darlehensförderung wird von allen Betriebstypen und -größen als „,eher unwichtig" eingestuft.

Etliche Betriebe ergänzen im Freitextfeld weitere politische Instrumente. Hierbei wird am häufigsten die Anerkennung von Naturschutzleistungen genannt. Zudem fordern mehrere Forstbetriebe die Vereinfachung der Beantragung von Fördergeldern. Auch Wünsche nach einem einheitlichen Vorgehen bei Kalamitäten werden geäußert, beispielsweise durch den Einsatz von Pflanzis nahme der Verkehrssicherungspflicht.

\section{Diskussion}

Die in der Umfrage erfasste durchschnittliche Betriebsgröße von etwa 957 ha ist im Vergleich zu den Daten der BWI3 keineswegs repräsentativ für die durchschnittlichen 2 ha aller deutschen Forstbetriebe (BMEL, 2012, 2017). Auch ist es nicht möglich, die Befragten geographisch innerhalb Deutschlands einzuordnen, da keine ortsbezogenen Daten erhoben wurden. Um die Aussagen auf ganz Deutschland zu beziehen, ist der Datensatz auch aufgrund der geringen Teilnehmerzahl un grund de

Allerdings zeigt sich bei der Betriebseinteilung nach den Eigentümerklassen der BWI3 dass fast 180000 ha auf die Eigentumsgrößenklasse ab 1000 ha entfallen. Dies sind etwa $25 \%$ aller deutschen Forstbetriebe dieser Größenklasse (BMEL, 2012, S. 31). Für diese Eigentümerklasse ist die Aussagekraft dementsprechend hoch.

Im Vergleich der Ergebnisse zur betrieblichen Zielsetzung, der Kalamität betroffenheit und den präferierten Maßnahmen zur Liquiditätssicherung zeigen sich jedoch wichtige allgemeine Tendenzen auch für die restlichen Betriebsgrößen, von denen prozentual 0,6 (bis 20 ha) bis $5 \%$ (500 bis 1000 ha) befragt wurden.

Es lässt sich erkennen, dass die betriebliche Organisation und Ausstattung einen Einfluss auf die Kalamitätsbewältigung besitzen. Forstbetriebe ohne eigenes Personal sind bei der Aufa beitung und Prävention von Kalamitätsholz auf externe Unterstützung angewiesen

Die Analyse der Ergebnisse zur steuerfreien Rücklage nach $\$ 3$ des ForstSchAusglG zeigt, dass die Rücklage nur in wenigen größeren Forstbetrieben gebildet wird. Zudem reicht die aktuell zurückgelegte Summe mit durchschnittlich etwa 80 Euro/ha je Betrieb mit einer Rücklage nicht aus, um die finanziellen Engpässe der letzten beiden Jahziellen Engpässe der letzten beiden Jah-
re zu kompensieren, geschweige denn zukünftige Liquiditätsengpässe auszuzukünftige Liquiditätsengpässe auszu-
gleichen. Über das Freitextfeld vermerken viele Betriebe ihre Unzufriedenheit mit der aktuellen Regelung.

Die Aussagen der Forstbetriebe erklären die geringe Anwendung der Rege-
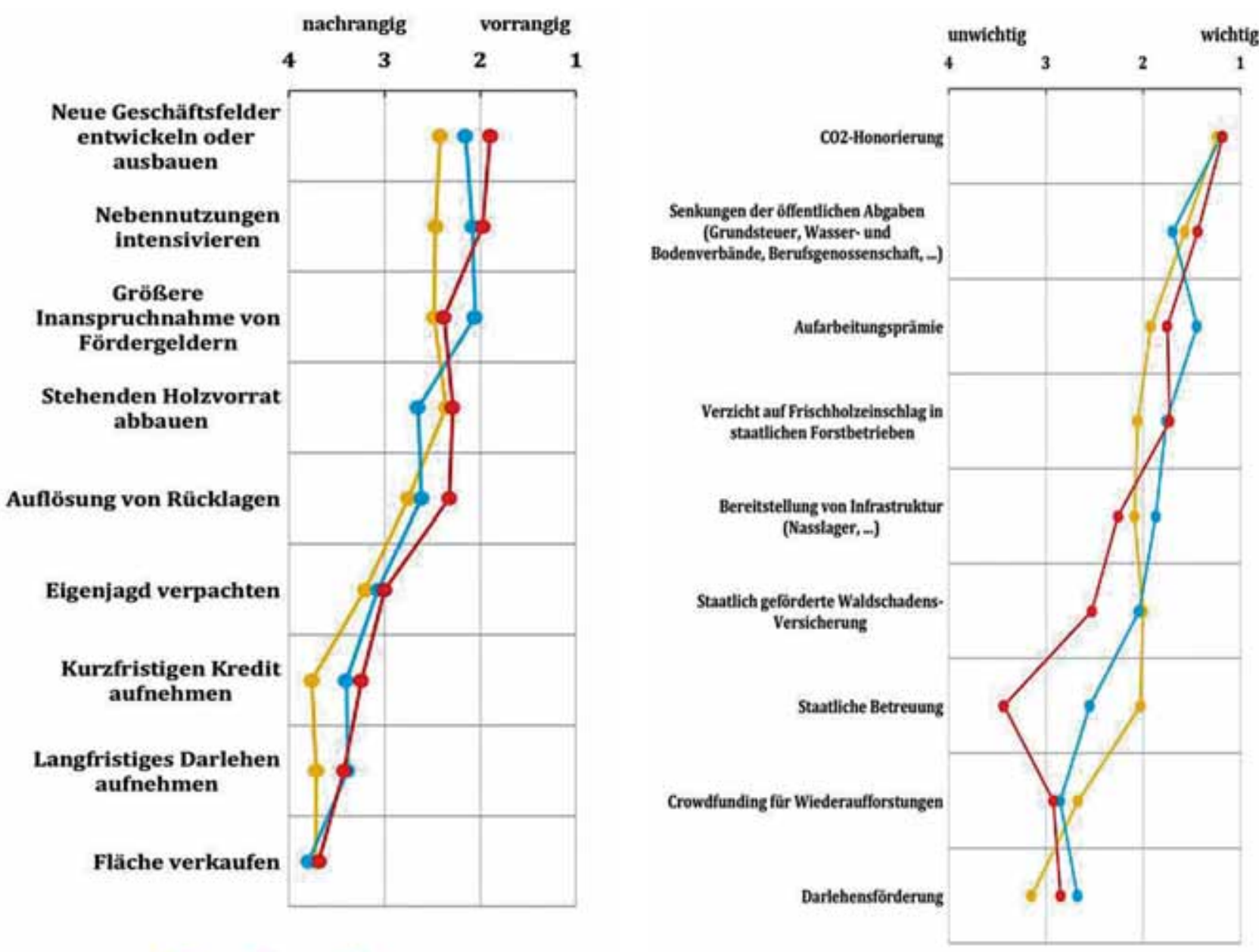

$*$ klein $*$ mittel $*$ groß

* klein * mittel * groß

Abbildung 5 Rangordnung verschiedener Maßnahmen zur Umsatzsteigerung nach Betriebsgröße $(n=108$ mit 24 kleinen, 50 mittleren und 34 großen Forstbetrieben). Ziffer 1 bedeutet: Maßnahmen in diesem Bereich werden vorrangig umgesetzt. Ziffer 4 bedeutet: Diese Maßnahmen werden vermieden.

lung durch den hohen Aufwand in de Bildung und Auflösung der Rücklage, sowie der Beschränkung der Regelung auf buchführungspflichtige Betriebe, von der nicht buchführungspflichtig Forstbetriebe nicht profitieren (Hog und Jöbstl, 1997). In der Theorie biete die Rechtsnorm Potenzial, um für Kalamitätsjahre Rücklagen zu bilden, allerdings erklären die aufgezählten Kritikpunkte den geringen Gebrauch diese Rechtsnorm, zumal die Rücklage den Forstbetrieben mit der größten relative Kalamitätsbelastung versagt bleibt.

Über das Finanzierungsverhalten von privaten Forstbetrieben ist recht weni bekannt, nicht zuletzt, weil die tatsächliche Höhe der Privatentnahmen und der Fremdkapitalaufnahmen in Betriebsvergleichen wie dem Forstbetriebsvergleich Westfalen-Lippe in de Regel nicht erfasst werden. Der Fragebogenteil zur betrieblichen Anpassungen nach einer Kalamität zielt auf die Erforschung des Finanzierungsverhaltens von Forstbetrieben ab. Die meis bevorzugte liquiditätssichernde $\mathrm{Ma} \beta-$ nahme der befragten Forstbetriebe is die Verringerung der Privatentnahmen. Diese dürfte betriebsspezifisch sehr unterschiedlich ausfallen. Es ist jedoch anzunehmen, dass diese Maßnahme allein noch nicht ausreicht, um in der laufenden Kalamitätssituation Liquiditätsengpässe im Betrieb zu vermeiden.

Insgesamt verdeutlichen die Ergebnisse der Umfrage, dass den forstpolitischen Instrumenten, insbesondere der
Honorierung der Klimaschutzleistung, eine große Bedeutung zur Verbesserung der finanziellen Situation von privaten Forstbetrieben zugemessen wird. Eine vorübergehende Entlastung über die che Abgaben könnte aus Sicht de Forstbetriebe ebenfalls zur Besserung beitragen. Für eine größere Inanspruchnahme von Fördermitteln der Forstbetriebe gilt es, die Maßnahmen bedarfsgerechter und effizienter zu gestalten, sodass der schnelle Abfluss von Gelleistet werden kann.

\section{Schlussfolgerungen}

Abschließend ist herauszustellen, dass in der aktuellen Kalamität die Finanzierung der Forstbetriebe durch ei ne Selbst- oder auch Umschichtungsfinanzierung aus dem Holzverkauf an ih re Grenzen stößt. Da Investitionsentscheidungen der privaten Forstbetriebe in Abhängigkeit der Finanzierungssituation getroffen werden müssen un private Forstbetriebe selbst bei Kalamität eine Fremdkapitalaufnahme vermeiden, werden vorrangig nur gewinnbringende oder gesetzlich vorgeschrieben Maßnahmen durchgeführt.

Die steuerfreie Rücklage als forstpolitisches Instrument kann daran aufgrund der geringen finanziellen Ausstattung, der eingeschränkten gesetzlichen Flexibilität nichts ändern. Die privaten Forstbetriebe erwarten daher finanziell Unterstützung der Öffentlichkeit über Stundung und den Verzicht auf öffentliVoraussetzungen und der mangelnden Ökosystemleistungen, die Entlastung von öffentlichen Abgaben und finanzielle Förderungen. Außerdem entwickeln die Forstbetriebe Ideen zu alternativen Einnahmequellen.

Im Hinblick auf die generationsübergreifende Waldbewirtschaftung in privaten Forstbetrieben erfordern der Wiederaufbau und die Klimaanpassung der Wälder insgesamt eine forstliche Intensivierung, insbesondere bei der Bestandesbegründung dem Waldschutz der desbegründung, dem Waldschutz, der Jagdausübung und der Bestandespflege. gen sowie Veränderungen der finanziellen forstpolitischen Rahmenbedingungen erforderlich. Nur so wird es innerhalb einer Marktwirtschaft möglich sein, das Interesse von privaten Waldbesitzer an der Anpassung der Wälder an den Klimawandel und an der nachhaltigen Waldbewirtschaftung zu erhalten. Der Walderhalt und die Bereitstellung von Ökosystemleistungen dienen schließlich der gesamten Bevölkerung.

Literatur

BMEL (2012): Ergebnisse der Bundeswaldin-
ventur 2012, 1-277 BMEL (2017): Waldbericht der Bundesregierung 2017. Bundesministerium für Ernährung
und Landwirtschaft, Bonn. (abgerufen am: 8. November 2019)

Hogg, J. N. und H. A. Jöbstl (1997): Zum Stand des forstlichen Rechnungswesens in einigen
europäischen Ländern. Forstwirtschaftliches europäischen Ländern. Forstwirtschaftliches
Centralblatt 114, 73-95 


\section{Study 4}

Title: Continuous timber harvest - Costly restriction or profitable solution?

\begin{tabular}{ll}
\hline Authors: & Johannes Wildberg, Bernhard Möhring \\
\hline Published in: & Forest Policy and Economics \\
\hline Year: & 2021 \\
\hline 5-year impact factor: & 3.665 \\
\hline DOI: & https://doi.org/10.1016/i.forpol.2020.102349
\end{tabular}

Author contribution: The authors Johannes Wildberg and Bernhard Möhring were involved in publishing this study. Both Johannes Wildberg and Bernhard Möhring developed the topic and model simulation. Johannes Wildberg wrote the article under the supervision of Bernhard Möhring. 


\title{
Continuous timber harvest — Costly restriction or profitable solution?
}

\author{
Johannes Wildberg *, Bernhard Möhring \\ Department of Forest Economics, University of Göttingen, Büsgenweg 3, 37077 Göttingen, Germany
}

\section{A R T I C L E I N F O}

\section{Keywords:}

Sustainability

Liquidity

Imperfect capital market

Differing borrowing and lending rates

Normal forest enterprise

\begin{abstract}
A B S T R A C T
In timber production, sustainability means maintaining resources by balancing timber harvest with timber growth. In forest management, sustainability also refers to a constant and steady flow of income. The aim of this study is to resolve the contradiction, whether a sustainable/continuous flow of timber income is a costly (incomereducing) restriction, or a comparatively profitable (income-increasing) solution. For that we relax the common assumption of a perfect capital market and consider differing borrowing and lending rates to incorporate the aspect of financial viability into forest management decisions.

Based on an established forest production model, we construct a synchronized "normal" forest enterprise and confront it with an interest rate on a perfect capital market and transform the forest enterprise to be optimal under the Faustmann-Pressler-Ohlin rule (FPO-rule). We do this by strictly following the FPO-harvesting-pattern, which immediately yields a perpetual non-constant (intermittent) flow of timber income. Alternatively, we simulate a long-term continuous forest enterprise transition, which ultimately results in a new normal forest structure with constant timber income. In a second step, we re-run the forest enterprise transitions under varying borrowing and lending rates, that differ as a function of capital availability within an imperfect capital market model. In both approaches, we derive and compare the maximum annual payout of the two alternative transition paths for an infinite time-horizon.

Our results show, that the normal forest enterprise structure no longer holds when the rotation age is adjusted to be optimal under the FPO-rule when capital markets are perfect. We highlight why the normal forest structure is often referred to as a costly restriction towards the question of the optimal harvesting age due to inefficient investment and financing costs. In an imperfect capital market, with differing borrowing and lending rates, creating a new normal forest stand structure appears to be economically favorable compared to a stand structure which yields non-constant income.

While our analysis does not provide universally valid evidence for the optimality of a normal forest, we are able to show that a constant flow of income can be favorable compared to non-constant income when the assumption of a perfect capital market is relaxed.
\end{abstract}

\section{Introduction}

The notion of sustainability originated in German forest management of the 18th century and has been subject to interpretation ever since (Speidel, 1972, p. 53). In managerial forest economics, the numerous conceptual aspects of sustainability can be roughly assigned to two categories: sustainability of a state (e.g. maintaining timber asset value) and sustainability of output (e.g. a consistent and continuous even flow of timber income) (Speidel, 1972, p. 54). It follows, that the sustainability of a forest enterprise is expressed in its ability to maintain enterprise value by producing an even flow of output and vice versa.
This demonstrates how sustainability is directly connected to the liquidity situation of a forest enterprise (Speidel, 1972, p. 59), which is a key indicator for a firm's financial viability.

The necessity of continuous output to sustain enterprise value, led to the idea of the so-called fully regulated or synchronized "normal" forest (based on Hundeshagen, 1826 and further developed by Heyer, 1841), where forestland is evenly divided into forest stands of consecutive ageclasses up to the rotation age (Aronsson and Löfgren, 1999; Salo and Tahvonen, 2002a). This age-class structure provides regular funding to invest in stand regeneration by harvesting mature stands at constant intervals (see Speidel, 1972, p. 100 ff.). As only a normal forest structure

\footnotetext{
* Corresponding author.

E-mail addresses: johannes.wildberg@uni-goettingen.de (J. Wildberg), bmoehri@gwdg.de (B. Möhring).
} 
can consistently secure financial viability of an enterprise, ${ }^{1}$ maintaining or establishing a normal forest should be prioritized above an individual forest stand's optimal harvesting age (Hundeshagen, 1826, p. 98).

The question of the optimal harvesting age of a forest stand is considered the classical problem in forest economics (Johansson and Löfgren, 1985, p. 73). The Faustmann-Pressler-Ohlin Theorem (FPOtheorem/rule) has been widely accepted as the correct solution to the rotation problem (Gerst, 2015, p. 11; Newman, 1988). The solution is based on neoclassical investment theory, where the investment (i.e. forest stand) is held until its marginal increase in value is equal to the cost of capital (i.e. land and stand holding costs) (see Johansson and Löfgren, 1985, p. 80). While postponing timber harvests past the optimal rotation age would lead to increased investment opportunity costs, premature harvests result in inefficient financing costs (see Möhring and Dieter, 2020). Because the theory behind the FPO-rule assumes no capital restriction and constant interest rates, the forest stand investment decision can be made independently from timber production income (see Fisher's separation theorem, 1930). This separability allows to determine the profitability of the (forest stand) investment independently from the investment objective to either maximize wealth or to maximize income, as these objectives coincide (see Kruschwitz and Lorenz, 2019, p. 68, 73 f.). Therefore, a forest owner has no incentive to secure a specific flow or regularity of timber income (see Tahvonen, 1998; Tahvonen and Viitala, 2006). On the contrary-constructing a forest with a normal age-class structure, at the cost of optimal forest stand maturity, would decrease overall profitably (see Mitra and Wan, 1985). This statement applies to the assumption of a perfect capital market, where the problems of liquidity and financial viability do not exist (see Hering, 2017, p. 33).

However, what is long known to forest practitioners is that liquidity plays an essential role in forest enterprises, just as it does in any other properly functioning businesses. External sources for financing are typically avoided not only because forest owners prefer to use their forest as a bank (Tahvonen et al., 2001), but also because credit is usually expensive, meaning that borrowers would pay higher interest than they would receive as lenders (see Brazee, 2003). In what is now considered an imperfect capital market (see Hering, 2017, p. 139), the problem of financial viability arises and can spiral to the point of insolvency.

In this regard, the aim of this study is to analyze the capital market imperfection of differing borrowing and lending rates using a simple model, to illustrate how decisions in forest stand structure and harvesting patterns may or may not be economically beneficial when we give up the assumption of the perfect capital market.

Studying capital market imperfections in the forest economics context is not new. The mentioning of capital market imperfections and the related forest owner preferences in Samuelson (1976), seems to have kicked off a series of studies, which integrate "imperfections" to the optimal harvesting problem, using i.a. two-period and Faustmann rotation models ${ }^{2}$ (see Brazee, 2003; Tahvonen et al., 2001). For one, the studies take into account owner specific factors on optimal timber harvesting, which include non-timber income and age (e.g. Binkley, 1981; Kuuluvainen and Salo, 1991), bequest motives (Tahvonen, 1998), in-situ values (e.g. Hartman, 1976; Ovaskainen, 1992; Tahvonen, 1998), uncertainty (e.g. Brazee and Mendelsohn, 1988; Norstrøm, 1975), risk preferences (Hahn et al., 2014) and non-linear utility (Mitra and Wan, 1985; Salo and Tahvonen, 2002b). Particularly the studies on capital market imperfections such as credit rationing (Tahvonen, 1998) and differing borrowing and lending rates (Murphy et al., 1977; Uusivuori and Kuuluvainen, 2001) emphasize the issues of financial viability in forestry and illustrate the forest owner specific liquidity problem (see also "Volvo argument" in Brazee, 2003; Johansson and Löfgren, 1985, p.

\footnotetext{
${ }^{1}$ Assuming that timber production is the only source of income.

${ }^{2}$ For a more detailed examination of the models see Tahvonen (1998).
}

138 f.). While these studies already show and indicate how capital market imperfections tend to lead to solutions that smooth timber harvest and income (Tahvonen, 1998; Uusivuori and Kuuluvainen, 2001), we wish to complement and expand on the previous works to support the following statement:

The profitability of irregular timber income associated with following the FPO-rule is conditional to the assumption of constant interest rates within a perfect capital market. If interest rates are no longer constant, the sustainable option (i.e. normal forest stand structure), which provides regular timber income, can become a comparatively profitable solution.

In order to support our statement-in which we intend to compare two mutually exclusive investment alternatives-we require a welldefined investment objective (see Kruschwitz and Lorenz, 2019, p. 8 f.), which is typically to maximize wealth or to maximize income (Kruschwitz and Lorenz, 2019, p. 10 ff. on Fisher, 1930 and Hirshleifer, 1958). In order to compare our alternatives under varying capital market conditions, we require the integration of a capital market model. To summarize, we require two fundamental components to support our statement: 1) a forest (enterprise) model that allows us to simulate two alternative investment paths (that yield either a periodic or a continuous stream of timber income) and 2) an appraisal method that appropriately considers a well-defined investment objective under varying capital market conditions.

Regarding 1), we set up a normal forest enterprise based on an established forest production model (see Möhring, 2010; Möhring and Dieter, 2020). We construct our initial forest enterprise with a nonoptimal rotation age when confronted with a constant interest rate within a perfect capital market. We transform the forest enterprise to adjust the rotation age to be optimal under the FPO-rule, which immediately yields a perpetual non-constant (intermittent) flow of timber income. Alternatively, we simulate a long-term continuous forest enterprise transition, which ultimately results in a new normal forest structure with constant perpetual timber income.

Regarding 2), we begin by comparing both sets of income streams on a perfect capital market using the partial investment calculations net present value (NPV) and annuity. The calculations demonstrate a fundamental element of Fisher's separation theorem, as maximum wealth (i.e. NPV) coincides with maximum income (i.e. annuity) within the perfect capital market, meaning no prior objective needs to be defined in order to determine the investment's profitability. In a second step, we explicitly expand our forest model with an external source/sink for financing/investing and show that the previously calculated annuity of the net timber income stream can be interpreted as the annual payout from the forest- and financial investment. In a third step, we incorporate differing borrowing and lending rates, which requires us to define an investment objective to be able to compare the investment alternatives as Fisher's separation no longer holds. We define maximization of the perpetual income as the investment objective, meaning the investment with a greater annual payout is considered favorable.

Our model and analysis show, that the initial steady flow of income and normal forest enterprise structure no longer hold and would become a costly restriction, when the rotation age is adjusted to be optimal under the FPO-rule with the assumption that capital markets are perfect. Then we show, that creating a new normal forest stand structure is comparatively advantageous to the FPO-harvesting-pattern, as borrowing and lending rates become dependent of capital availability (volume-dependent interest rate). Even though our approach provides no formal proof for the universal profitability of a normal forest structure, we are able to provide support that a continuous flow of income can be favorable when the assumption of a perfect capital market is relaxed.

Our approach differs from other studies that consider differing borrowing and lending rates such as Murphy et al. (1977) because we use differing borrowing and lending rates that vary with the amount of capital borrowed or lent. While Uusivuori and Kuuluvainen (2001) 
analyze the problem of differing borrowing and lending rates in terms of forest owner collaboration, we focus on the economics of forest stand age structure within an individual forest enterprise. While there are several studies on the economics of normal forests (e.g. Comolli, 1981; Hultkrantz, 1991; Oderwald and Duerr, 1990), we are not aware of studies that specifically integrate a capital-volume dependent interest rate to contrast a periodic versus a continuous flow of timber income within the normal forest framework. Because of this capital-volume dependency of the interest rate, we are not able to develop a general analytic solution, but describe a transparent and easy-to-follow numerical example.

The paper is organized as follows. In section 2, we introduce the forest production model, construct a normal forest enterprise from it and outline our capital market model. In section 3 we implement the forest enterprise transitions and analyze our results. In section 4 we discuss our results and draw concluding remarks.

\section{Model and theoretical background}

In this section we describe the forest stand production model, use it to develop the normal forest enterprise and pick up on the relevant aspects of forest economics and capital market theory along the way. Note that in the model and the analysis that follows, we assume maximization of wealth and/or income from timber production under varying capital market conditions as the only objective and do not include e.g. risk or multiple land-use considerations. We also assume that non-forest financial assets and timber assets are perfect substitutes.

\subsection{Forest stand production model}

We apply an established single species model, which has been used in

a

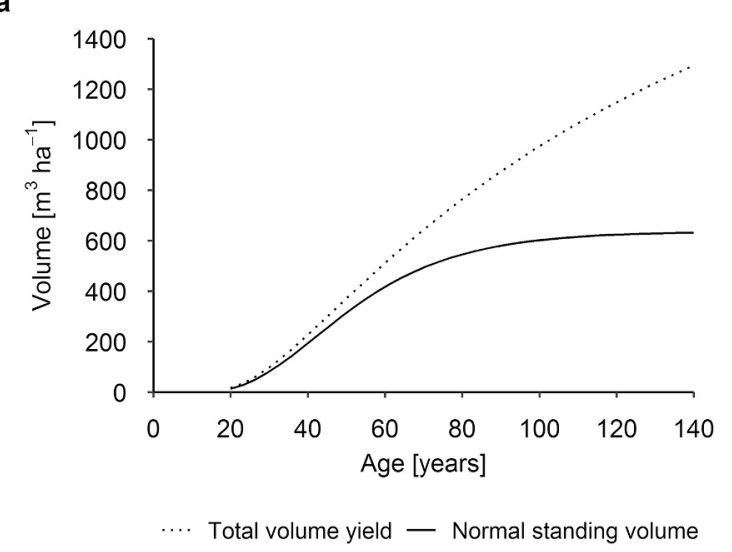

Möhring and Dieter (2020). A similar model with past income and cost figures was used in Möhring (2010). The model fulfills the simplified condition of a spruce (Picea abies) forest with a 100-year site index of $29.2 \mathrm{~m}$ (i.e. 2nd yield class) in northern Germany. It is possible to adapt the model to other tree species and site qualities.

\subsubsection{Underlying functions}

The model is based on non-linear functions (Fig. 1): (a) The normal standing volume and a growth function showing the total volume yield (standing tree cubic volume per hectare), which was developed by Smaltschinski (2001) and is based on the yield tables of Wiedemann (1936/42); Schober (1995). The growth function is used to derive the annual volume increment (annual current increment or incremental growth) as seen in (b). For the economic valuation the model uses a mean revenues from timber sales function (Spellmann, 2017) and a mean timber harvesting cost function (Bodelschwingh, 2018) to derive the contribution margin from timber production (contribution margin I), which is dependent on the mean net volume per tree (c).

\subsubsection{Modelling forest stand development}

Based on the previously mentioned functions (Fig. 1, a-b) we simulate the natural development of a spruce forest stand. For the sake of clarity, we use 10-year discrete periods in the following tables. In Table 1 (lines 1-19) the key figures such as standing volume, timber harvest and current volume increment are shown. The simulation starts at 20 years and we assume a starting stem count of 1000 stems per hectare. We include light thinning directed at a stocking density level of 1.0. Standing tree volume (referred to as volume) is converted to harvested tree volume (referred to as net volume) using a factor of 0.8 and is expressed in solid cubic meters.

The economic development of the forest stand throughout the years

b -

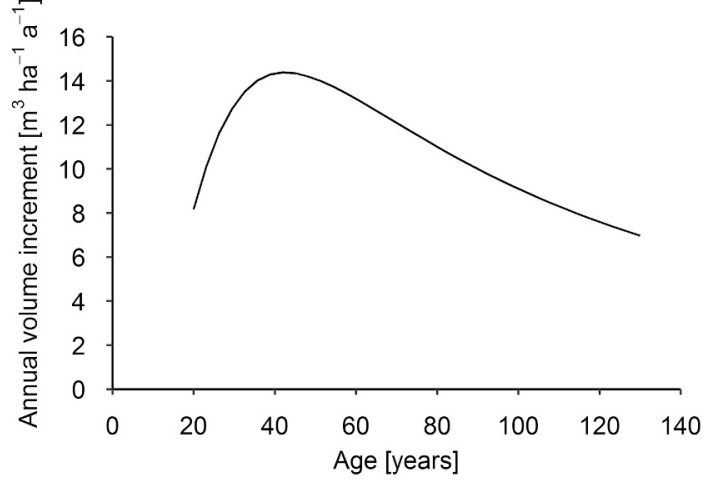

c

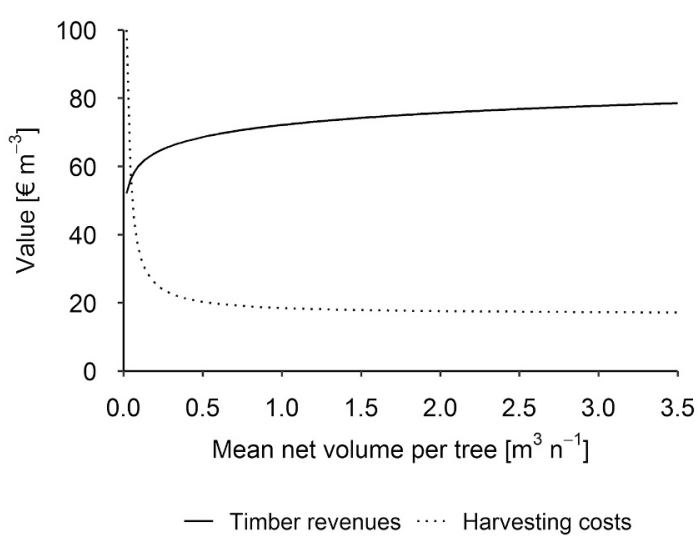

Fig. 1. Underlying functions of the forest stand production model (adapted from Möhring, 2010 and Möhring and Dieter, 2020). 
Table 1

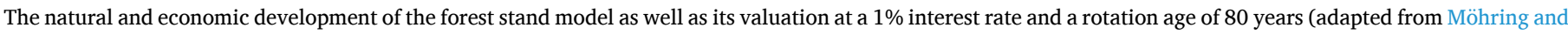
Dieter, 2020).

\begin{tabular}{|c|c|c|c|c|c|c|c|c|c|c|c|c|c|}
\hline & Age & Years & 0 & 10 & 20 & 30 & 40 & 50 & 60 & 70 & 80 & 90 & 100 \\
\hline 1 & Natural development & & & & & & & & & & & & \\
\hline 2 & Stand (start of 10-year period) & & & & & & & & & & & & \\
\hline 3 & Volume & $\mathrm{m}^{3} \mathrm{ha}^{-1}$ & & & 13.27 & 94.93 & 210.41 & 336.68 & 455.43 & 549.49 & 614.66 & 655.79 & 679.86 \\
\hline 4 & Net volume & $\mathrm{m}^{3} \mathrm{ha}^{-1}$ & & & 10.61 & 75.94 & 168.33 & 269.34 & 364.34 & 439.59 & 491.73 & 524.63 & 543.89 \\
\hline 5 & Stem count & $\mathrm{n} \mathrm{ha}^{-1}$ & & & 1000 & 1000 & 858 & 789 & 737 & 676 & 607 & 539 & 477 \\
\hline 6 & Mean net volume per tree & $\mathrm{m}^{3} \mathrm{n}^{-1}$ & & & 0.01 & 0.08 & 0.20 & 0.34 & 0.49 & 0.65 & 0.81 & 0.97 & 1.14 \\
\hline 7 & Total volume yield & $\mathrm{m}^{3} \mathrm{ha}^{-1}$ & & & 13.27 & 94.93 & 223.85 & 367.20 & 508.09 & 639.95 & 760.88 & 870.96 & 971.00 \\
\hline 8 & Harvested stand & & & & & & & & & & & & \\
\hline 9 & Volume & $\%$ & & & $0 \%$ & $14.2 \%$ & $8.1 \%$ & $6.6 \%$ & $8.3 \%$ & $10.1 \%$ & $11.2 \%$ & $11.6 \%$ & $11.5 \%$ \\
\hline 10 & Volume & $\mathrm{m}^{3} \mathrm{ha}^{-1}$ & & & 0.00 & 13.44 & 17.08 & 22.15 & 37.79 & 55.76 & 68.95 & 75.97 & 78.15 \\
\hline 11 & Net volume & $\mathrm{m}^{3} \mathrm{ha}^{-1}$ & & & 0.00 & 10.75 & 13.67 & 17.72 & 30.23 & 44.61 & 55.16 & 60.77 & 62.52 \\
\hline 12 & Stem count & $\mathrm{n} \mathrm{ha}^{-1}$ & & & 0 & 142 & 70 & 52 & 61 & 69 & 68 & 62 & 55 \\
\hline 13 & Mean net volume per tree & $m^{3} n^{-1}$ & & & & 0.08 & 0.20 & 0.34 & 0.49 & 0.65 & 0.81 & 0.97 & 1.14 \\
\hline 14 & $\begin{array}{l}\text { Remaining stand (end of 10-year } \\
\text { period) }\end{array}$ & & & & & & & & & & & & \\
\hline 15 & Volume & $\mathrm{m}^{3} \mathrm{ha}^{-1}$ & & & 13.27 & 81.49 & 193.33 & 314.53 & 417.64 & 493.73 & 545.71 & 579.82 & 601.71 \\
\hline 16 & Net volume & $\mathrm{m}^{3} \mathrm{ha}^{-1}$ & & & 10.61 & 65.19 & 154.66 & 251.62 & 334.11 & 394.98 & 436.57 & 463.86 & 481.37 \\
\hline 17 & Stem count & $\mathrm{n} \mathrm{ha} \mathrm{a}^{-1}$ & & & 1000 & 858 & 789 & 737 & 676 & 607 & 539 & 477 & 422 \\
\hline 18 & Annual current increment & & & & & & & & & & & & \\
\hline 19 & Volume increment & $\begin{array}{l}\mathrm{m}^{3} \mathrm{ha}^{-1} \\
\mathrm{a}^{-1}\end{array}$ & & & 8.17 & 12.89 & 14.34 & 14.09 & 13.19 & 12.09 & 11.01 & 10.00 & 9.10 \\
\hline 20 & Economic development & & & & & & & & & & & & \\
\hline 21 & Stand (start of 10-year period) & & & & & & & & & & & & \\
\hline 22 & Timber revenues & $€ \mathrm{~m}^{-3}$ & & & 48.86 & 58.94 & 63.79 & 66.63 & 68.53 & 69.93 & 71.05 & 71.99 & 72.81 \\
\hline 23 & Timber harvesting costs & $€ \mathrm{~m}^{-3}$ & & & 187.95 & 40.61 & 25.94 & 22.00 & 20.35 & 19.47 & 18.92 & 18.54 & 18.27 \\
\hline 24 & Contribution margin I & $€ \mathrm{~m}^{-3}$ & & & -139.10 & 18.33 & 37.85 & 44.64 & 48.18 & 50.47 & 52.14 & 53.45 & 54.54 \\
\hline 25 & Value & $€$ ha $^{-1}$ & & & -1476 & 1392 & 6371 & 12,022 & 17,553 & 22,184 & 25,637 & 28,044 & 29,666 \\
\hline 26 & Harvested stand & & & & & & & & & & & & \\
\hline 27 & Value & $€$ ha $^{-1}$ & & & 0.00 & 196.99 & 517.28 & 790.83 & 1457 & 2251 & 2876 & 3249 & 3410 \\
\hline 28 & $\begin{array}{l}\text { Remaining stand (end of 10-year } \\
\text { period) }\end{array}$ & & & & & & & & & & & & \\
\hline 29 & Value & $€$ ha $^{-1}$ & & & -1476 & 1195 & 5854 & 11,232 & 16,097 & 19,933 & 22,761 & 24,795 & 26,256 \\
\hline 30 & Annual current increment & & & & & & & & & & & & \\
\hline 31 & Value increment & $€ \mathrm{ha}^{-1} \mathrm{a}^{-1}$ & & & 286.79 & 517.62 & 616.87 & 632.17 & 608.74 & 570.43 & 528.27 & 487.05 & 448.70 \\
\hline 32 & Cash flow; rotation age 80 & & & & & & & & & & & & \\
\hline 33 & Silvicultural costs & $€$ ha $^{-1}$ & 2000 & 400.00 & & & & & & & & & \\
\hline 34 & Contribution margin I (thinning) & $€ \mathrm{ha}^{-1}$ & 0.00 & 0.00 & 0.00 & 196.99 & 517.28 & 790.83 & 1457 & 2251 & 0.00 & & \\
\hline 35 & $\begin{array}{l}\text { Contribution margin I (final } \\
\text { harvest) }\end{array}$ & $€$ ha $^{-1}$ & 0.00 & 0.00 & 0.00 & 0.00 & 0.00 & 0.00 & 0.00 & 0.00 & 25,637 & & \\
\hline 36 & Cash flow & $€$ ha $^{-1}$ & -2000 & -400.00 & 0.00 & 196.99 & 517.28 & 790.83 & 1457 & 2251 & 25,637 & & \\
\hline 37 & Valuation; interest rate $1 \%$ & & & & & & & & & & & & \\
\hline 38 & Discount factor & & 1.00 & 0.91 & 0.82 & 0.74 & 0.67 & 0.61 & 0.55 & 0.50 & 0.45 & & \\
\hline 39 & Present value & $€ \mathrm{ha}^{-1}$ & -2000 & -362.11 & 0.00 & 146.15 & 347.43 & 480.86 & 801.73 & 1122 & 11,565 & & \\
\hline 40 & Sum of discounted cash flow & $€ \mathrm{ha}^{-1}$ & 12,101 & & & & & & & & & & \\
\hline 41 & Gross soil rent & $€ \mathrm{ha}^{-1} \mathrm{a}^{-1}$ & 220.47 & & & & & & & & & & \\
\hline 42 & Fixed overhead costs & $€ \mathrm{ha}^{-1} \mathrm{a}^{-1}$ & 100.00 & & & & & & & & & & \\
\hline 43 & Net soil rent & $€ \mathrm{ha}^{-1} \mathrm{a}^{-1}$ & 120.47 & & & & & & & & & & \\
\hline 44 & Land expectation value & $€ \mathrm{ha}^{-1}$ & 12,047 & & & & & & & & & & \\
\hline
\end{tabular}

is directly based on the natural development and the underlying revenue and cost function of Fig. 1 (c). Table 1 (lines 20-31) shows the value of the forest stand minus the value of the pre-harvested (thinned) timber. Furthermore, the model includes the cost of establishing a stand $(2000 €$ $\mathrm{ha}^{-1}$ ), stand tending costs at the age of 10 (400.00€ ha ${ }^{-1}$ ) and annual fixed costs for administration, road construction, forest protection, etc. $\left(100.00 € \mathrm{ha}^{-1} \mathrm{a}^{-1}\right)$.

Depending on the selected rotation age, the natural development and the associated economic activity of the forest stand result in a cash flow (Table 1, lines 32-36) as the basis for the following valuation of the forest management strategy in section 2.2.

\subsection{Forest management strategy valuation, the interest rate and optimal rotation age}

In the following section, we derive the cash flow from the forest stand at an exemplary rotation age of 80 years. We introduce and clarify in this context the role of an exogenous interest rate and determine the optimal rotation age for our forest stand model by maximizing the net soil rent. Table 1 (line 36) shows the cash flow generated from the forest stand 
throughout the course of 80 years. The cash flow is the result of the previously mentioned pre- and final harvesting revenues as well as the harvesting and silvicultural costs. For our valuation we assume an interest rate of $1 \%$, which allows us to calculate the present value of the single cash flow payments (Table 1, line 39) and the sum of the discounted cash flow of the first rotation (Table 1, line 40). For an easier and a more practical way to interpret the sum of the discounted cash flow, the gross soil rent is derived. The gross soil rent is an expression of the summed discounted cash flow as an annual constant value (Möhring et al., 2006) and can be found in Table 1 (line 41). By subtracting the annual fixed overhead costs from the gross soil rent, we receive the net soil rent as a key economic figure for our analysis (Table 1, line 43). The net soil rent can alternatively be derived and expressed using the following equation (notation adapted from Möhring and Dieter, 2020):

$s_{n}=\frac{r^{*}(1+r)^{u}}{(1+r)^{u}-1} *\left(\frac{A_{u}}{(1+r)^{u}}+\sum_{a=1}^{u} \frac{D_{a}}{(1+r)^{a}}-\frac{t_{q}}{(1+r)^{q}}-c\right)-v$

with

$A_{u}$ Contribution margin I from final harvest

$D_{a}$ Contribution margin I from thinning

$t_{q} \quad$ Stand tending costs

c Stand establishment costs

$v$ Annual fixed overhead costs

$u$ Rotation age

a Age of thinning

$q$ Age of stand tending

$r$ Interest rate

The net soil rent is the monetary amount that can be annually withdrawn throughout the forest stand rotation period. Capitalization of the perpetual net soil rent (assuming identical forest production in consecutive rotation periods) yields the land expectation value (LEV) as per "Faustmann formula", which calculates the value the bare forest land possesses in perpetuity (Faustmann, 1849). The land expectation value (Table 1, line 44) can be interpreted as the willingness to pay for land (Klemperer, 1996, p. 204 ff.).

In regard to the FPO-rule, the rotation age that maximizes LEV at a given interest rate is considered optimal (see Johansson and Löfgren, 1985, p. 79 f.). Due to the previously described connection between the LEV and the net soil rent, the optimal rotation period can be derived by finding the rotation age that maximizes the net soil rent (see Möhring, 2001). Fig. 2 shows the net soil rent at discrete rotation ages of 10 -year periods for varying interest rates.

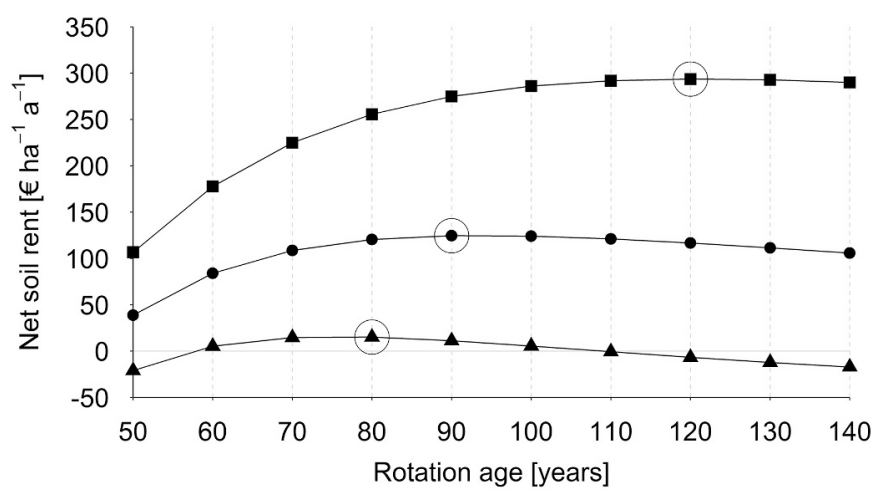

Interest rate - $0 \% \cdot 1 \% \Delta 2 \%$

Fig. 2. The net soil rent for varying rotation ages and interest rates. The maximum net soil rent for each interest rate is marked with a circle revealing the optimal rotation age.
Fig. 2 shows that the highest net soil rent is reached at a 90-year rotation age at an interest rate of $1 \%$. It is worth noting that an interest rate of $0 \%$ the net soil rent is equal to the net timber income of a normal synchronized forest (Möhring, 2001; Möhring, 1994, p. 74 f.), which we now construct from our forest stand model in the following section.

\subsection{Modelling and appraisal of a normal forest enterprise}

From the previously described natural and economic forest stand development, we construct a normal or fully regulated forest enterprise of 100 ha in size. We assume the normal forest enterprise has an exemplary initial rotation age of 80 years (see Table 2).

The aggregated economic figures of the normal forest enterprise are shown in Table 3 . As seen in Table 3 (line 8 ) the annual net timber income of the normal forest enterprise is $255.62 € \mathrm{ha}^{-1} \mathrm{a}^{-1}$, which corresponds to the net soil rent of the forest stand development at a $0 \%$ interest rate. Similar to the net soil rent, the net timber income can be regarded as both the maximum monetary amount possible and minimum amount required to be withdrawn from the forest enterprise in order to maintain its regulated state at the given rotation age.

\subsection{From the perfect to the imperfect capital market model}

In the previous sections, we constructed a normal forest enterprise from our forest stand model. For the valuation of the forest management strategy we assumed an exogenous interest rate of $1 \%$ and derived the net soil rent, which reaches its maximum at a 90 -year rotation period. Hence, the oldest forest stands in the given normal forest enterprise model with the rotation age of 80 years are 10 years away from reaching optimal maturity. With our non-optimal normal forest enterprise, we set the scene for implementing our model in section 3 and created an incentive to transform the forest enterprise to reach optimal maturity. In order to emphasize and highlight the investive character of the forest enterprise transition, we extend our forest enterprise model with an alternative external source/sink for financing/investing (i.e. bank account). This allows us to highlight the financing aspect of the transition (i.e. where does the money to fund the transition come from?) under perfect but also imperfect capital market conditions where interest rates are no longer constant. However, when interest rates are no longer constant, meaning there is no exogenous interest rate of $1 \%$, the profitability calculation becomes more complex as the respective interest rate cannot be determined a priori (Hering, 2017, p. 142).

In order to consider our imperfect capital market within the same model as our perfect capital market, we provide our external source/sink for financing/investing (i.e. bank account) with a capital-volume dependent interest rate function, which can be adjusted to integrate varying intensities of capital market imperfection. The degree of capital market imperfection is expressed by the slope of an interest rate curve, showing the borrowing and lending rates that differ as a function of capital availability (Fig. 3).

In Fig. 3, the interest rate depends on the capital borrowed for financing or lent for investment and the degree of capital market imperfection. The degree of capital market imperfection is expressed by the deviation between borrowing and lending rates in percentage points (pp) between the displayed range of -300 and 300 thousand euros. The corresponding interest rate for capital borrowed or lent as seen in Fig. 3 is calculated using the following equation:

$f(r, x, z)=r^{*} e^{-\left(\frac{x}{z}\right)}$

with

$r$ Interest rate, where $\{r \in \mathbb{R} \mid r=0.01\}$

$x$ Capital in thousand $€$

$z$ Factor 
Table 2

Inventory data and timber harvest of the normal forest enterprise of 100 ha in size and a rotation age of 80 years.

\begin{tabular}{|c|c|c|c|c|c|c|c|c|c|c|c|c|c|}
\hline & Age & Years & $1-10$ & $11-20$ & $21-30$ & $31-40$ & $41-50$ & $51-60$ & $61-70$ & $71-80$ & $81-90$ & $91-100$ & $\Sigma$ \\
\hline 1 & \multicolumn{13}{|l|}{ Inventory data } \\
\hline 2 & Area & ha & 12.50 & 12.50 & 12.50 & 12.50 & 12.50 & 12.50 & 12.50 & 12.50 & & & 100.00 \\
\hline 3 & Volume & $\mathrm{m}^{3} \mathrm{ha}^{-1}$ & 0.00 & 0.83 & 6.76 & 18.24 & 33.13 & 48.12 & 60.45 & 69.27 & & & 236.80 \\
\hline 4 & Stumpage value & $€ \mathrm{ha}^{-1}$ & 0.00 & -92.26 & -5.27 & 472.86 & 1117 & 1799 & 2393 & 2848 & & & 8532 \\
\hline 5 & \multicolumn{13}{|l|}{ Thinning } \\
\hline 6 & Area & ha & 12.50 & 12.50 & 12.50 & 12.50 & 12.50 & 12.50 & 12.50 & 0.00 & & & 87.50 \\
\hline 7 & Volume & $\mathrm{m}^{3} \mathrm{ha}^{-1} \mathrm{a}^{-1}$ & 0.00 & 0.00 & 0.17 & 0.21 & 0.28 & 0.47 & 0.70 & 0.00 & & & 1.83 \\
\hline 8 & Net volume & $\mathrm{m}^{3} \mathrm{ha}^{-1} \mathrm{a}^{-1}$ & 0.00 & 0.00 & 0.13 & 0.17 & 0.22 & 0.38 & 0.56 & 0.00 & & & 1.46 \\
\hline 9 & Contribution margin I (thinning) & $€ \mathrm{ha}^{-1} \mathrm{a}^{-1}$ & 0.00 & 0.00 & 2.46 & 6.47 & 9.89 & 18.21 & 28.14 & 0.00 & & & 65.16 \\
\hline 10 & \multicolumn{13}{|l|}{ Final harvest } \\
\hline 11 & Area & ha $\mathrm{a}^{-1}$ & & & & & & & & 1.25 & & & 1.25 \\
\hline 12 & Volume & $\mathrm{m}^{3} \mathrm{ha}^{-1} \mathrm{a}^{-1}$ & & & & & & & & 7.68 & & & 7.68 \\
\hline 13 & Net volume & $\mathrm{m}^{3} \mathrm{ha}^{-1} \mathrm{a}^{-1}$ & & & & & & & & 6.15 & & & 6.15 \\
\hline 14 & Contribution margin I (final harvest) & $€ \mathrm{ha}^{-1} \mathrm{a}^{-1}$ & & & & & & & & 320.46 & & & 320.46 \\
\hline
\end{tabular}

Table 3

Aggregated economic figures from Table 2 of the normal forest enterprise at a rotation age of 80 years.

\begin{tabular}{llll}
\hline 1 & Area & ha & 100.00 \\
2 & Standing timber & $\mathrm{m}^{3} \mathrm{ha}^{-1}$ & 236.80 \\
3 & Stumpage value & $€ \mathrm{ha}^{-1}$ & 8532 \\
4 & Harvest area & $\mathrm{ha} \mathrm{a}^{-1}$ & 1.25 \\
5 & Harvested timber & $\mathrm{m}^{3} \mathrm{ha}^{-1} \mathrm{a}^{-1}$ & 7.61 \\
6 & Contribution margin I & $€ \mathrm{ha}^{-1} \mathrm{a}^{-1}$ & 385.62 \\
7 & Variable and fixed overhead costs & $€ \mathrm{ha}^{-1} \mathrm{a}^{-1}$ & 130.00 \\
\hline 8 & Net timber income & $€ \mathbf{h a}^{-\mathbf{1}} \mathrm{a}^{-\mathbf{1}}$ & $\mathbf{2 5 5 . 6 2}$ \\
\hline
\end{tabular}

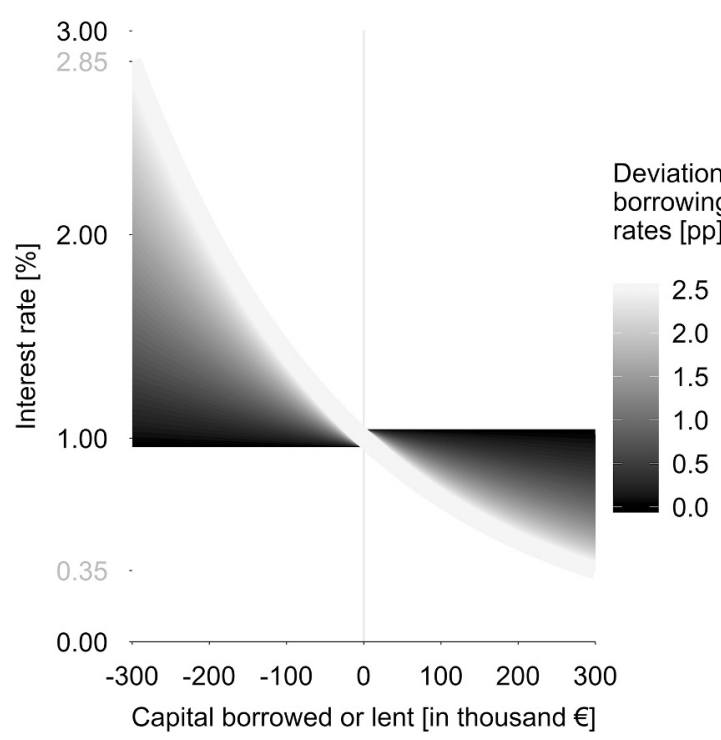

Fig. 3. Illustration of the interest rate function showing a constant interest rate of $1 \%$ within the perfect capital market and varying intensities of a capitalvolume dependent interest rate within the imperfect capital market.

In our analysis the interest rate becomes dependent on the amount of capital borrowed or lent and the degree of the capital market imperfection. The capital market imperfection is adjusted using the factor $z$. The capital market is perfect when the factor $z$ in Eq. (2) tends to infinity, so that the quotient $x / z$ tends to 0 and the interest rate $r$ of $1 \%$ is constantly multiplied by 1 (independent of the amount of capital borrowed or lent). The capital market becomes increasingly imperfect as the factor $z$ decreases. For our analysis, we decrease factor $z$ until a deviation between borrowing and lending rates of $2.5 \mathrm{pp}$ (between the relevant -300 and 300 thousand euros) is reached (see Fig. 3). -300 to 300 thousand euros is the range in which capital will be borrowed/lent when transforming the 100 ha normal forest enterprise.

\section{Model implementation and analysis}

In our analysis, we apply our previously constructed normal forest enterprise of 100 ha in size and an 80-year rotation age and confront it with an exogenous interest rate of $1 \%$ so that the rotation age becomes non-optimal in regard to the FPO-rule on a perfect capital market. First, we transform the forest enterprise by increasing the rotation age to 90 years by strictly following the periodic FPO-harvesting-pattern meaning stands are harvested when they reach the age of maturity. This transition is referred to as "periodic transition". In a second approach, we transform the forest enterprise continuously so that it returns to the normal forest enterprise structure after transition with an increased rotation age of 90 years. This transition is referred to as "continuous transition". We calculate economic profitability of both the periodic and continuous transition by calculating the NPV/annuity of the enterprise's net timber income. In a second step, we introduce an external source/sink for financing/investment in the form of a credit/debit bank account to visualize the actual flow of payments and in order to highlight the financing aspect of the two forest transitions. This allows us to show how the annuity of the net timber income during and after the forest transition can be interpreted as the maximum annual payout from investment.

For the second part of our analysis, we repeat both the periodic and continuous enterprise transitions under imperfect capital market conditions. By using our external source/sink for financing and investing with our integrated capital market interest rate model, we adjust the interest rate curve of borrowing and lending rates and calculate the maximum annual payout for an increasingly imperfect capital market.

\subsection{Age-class development of the forest enterprise transitions}

The analysis begins with the initial fully regulated normal forest enterprise of 100 ha and a rotation age of 80 years. The 100 ha of the forest enterprise are divided into 8 age-classes, which are each 12.5 ha in size. The rotation age of the forest enterprise is adjusted from 80 to 90 years. Fig. 4 shows the development of the forest enterprise area for both the periodic and the continuous transition.

After the first decade of the periodic transition, all age-classes grow 10 years older as the forest stands remain untouched except for regular pre-harvesting (thinning). After 10 years, the forest enterprise now 

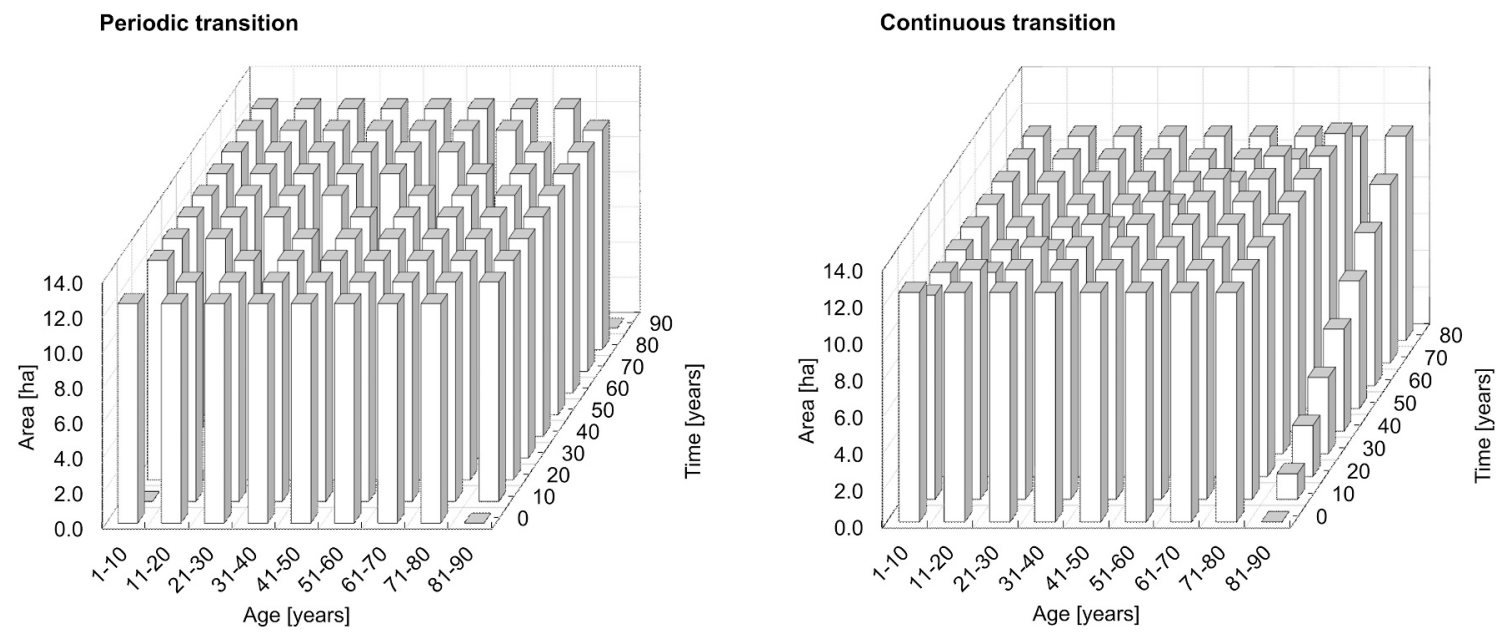

Fig. 4. Age-class transition of the normal forest enterprise from the initial starting situation with a rotation age of 80 years to a rotation age of 90 years. The transition is done periodically (left) and continuously (right).

consists of 8 fully stocked age-classes of initial size (12.5 ha) as well as a missing 1st age-class creating a moving age-class gap throughout the development of the forest enterprise in the decades that follow. The transition is never really completed, as the initial normal forest is now turned to a non-normal forest stand structure.

The continuous transition on the other hand is completed after 80 years. During the first 80 years, the initial normal forest enterprise temporarily loses its normal structure, as it is gradually turned into a new normal forest enterprise with an extra age-class. This is achieved, as the annually harvested area decreases from initially 1.25 ha to 1.11 ha, so that a gradually increasing portion of the 71-80-year age-class grows into the 81-90-year age-class. This leads to an overall decrease in areal size per age-class from 12.5 ha to 11.1 ha in the course of 80 years.

\subsection{Net timber income development of the forest enterprise transitions}

Initially, the forest enterprise produced an annual constant net timber income of $255.62 € \mathrm{ha}^{-1} \mathrm{a}^{-1}$ as described in section 2.3 (Table 3). Expectedly, the periodic and continuous transition yield two different net timber income streams that deviate from the initial constant net timber income as seen in Fig. 5.

Fig. 5 shows the development of the net timber income during and after the forest enterprise transitions.

For the periodic transition, the net timber income decreases for the first 10 years as no forest stands are harvested. In fact, in the first 10 years the net timber income is negative due to stand tending and fixed overhead costs. After 10 years, the first 90-year-old mature stands are harvested. Since the average age of the forest stands has now increased (it is now at its highest point), the net timber income is higher compared to the initial 80-year-old normal forest (also due to higher revenues from thinning and no stand tending costs). The initial continuous flow of net

Table 4

Net present value and annuity of net timber income for the periodic and continuous forest enterprise transitions compared to the initial normal forest enterprise.

\begin{tabular}{llllll}
\hline & Interest rate 1\% & & $\begin{array}{l}\text { Initial } \\
\text { state }\end{array}$ & $\begin{array}{l}\text { Periodic } \\
\text { transition }\end{array}$ & $\begin{array}{l}\text { Continuous } \\
\text { transition }\end{array}$ \\
\hline 1 & Rotation age & years & 80 & 90 & 90 \\
2 & $\begin{array}{l}\text { NPV of net } \\
\text { timber income }\end{array}$ & $€$ ha $^{-1}$ & 25,562 & 26,187 & 25,996 \\
3 & $\begin{array}{l}\text { Annuity of net } \\
\text { timber income }\end{array}$ & $€$ & $\mathbf{2 5 5 . 6 2}$ & $\mathbf{2 6 1 . 8 7}$ & $\mathbf{2 5 9 . 9 6}$ \\
\hline
\end{tabular}

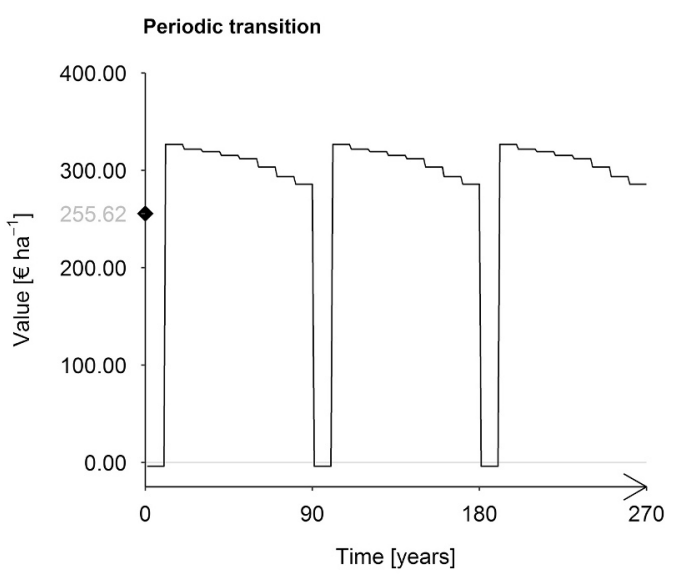

- Net timber income prior to transition

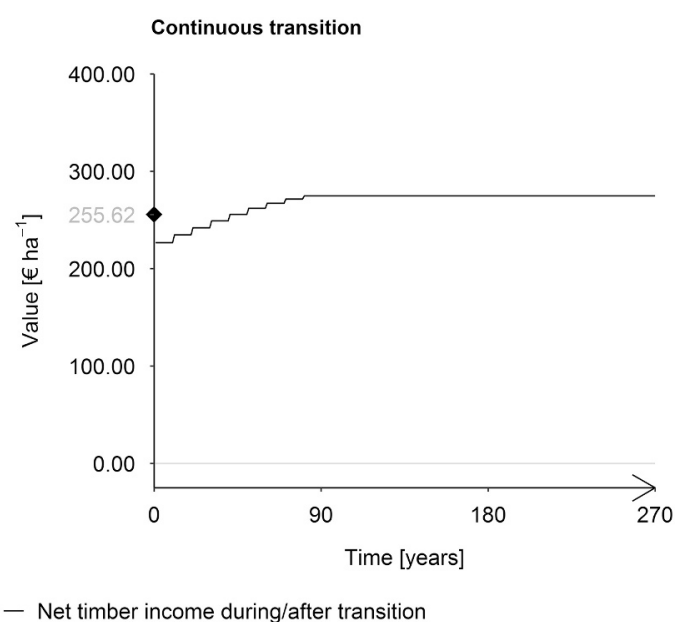

Fig. 5. Development of the net timber income resulting from the periodic transition (left) and the continuous transition (right). 


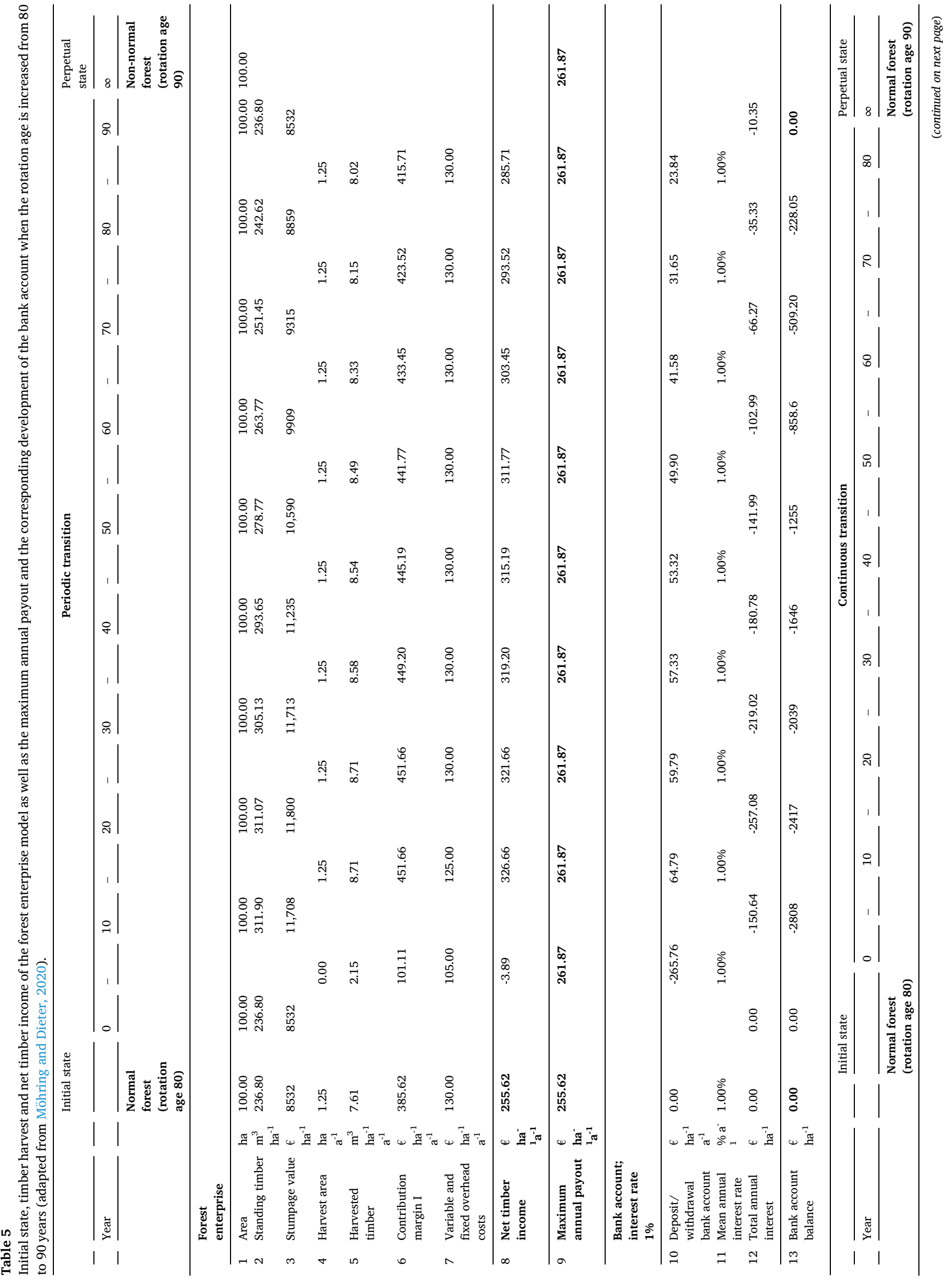




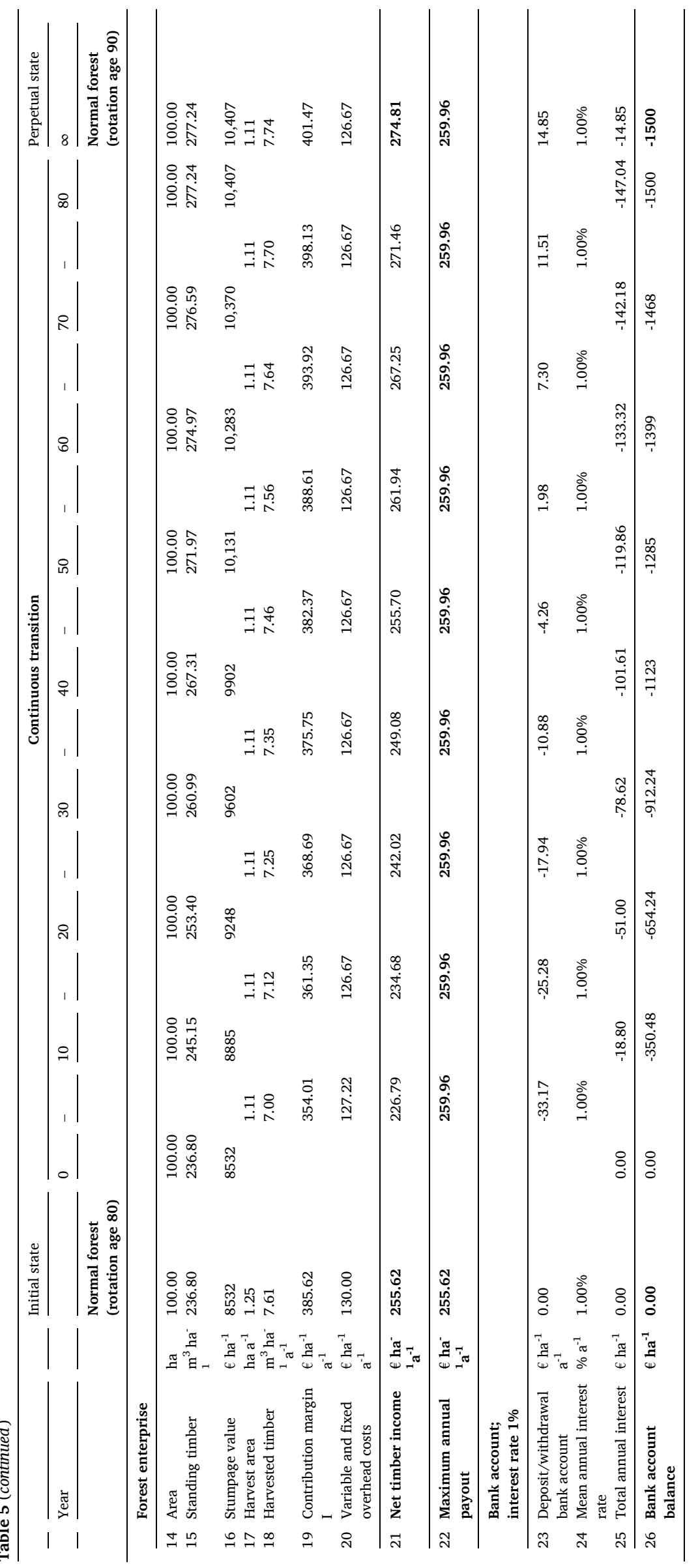




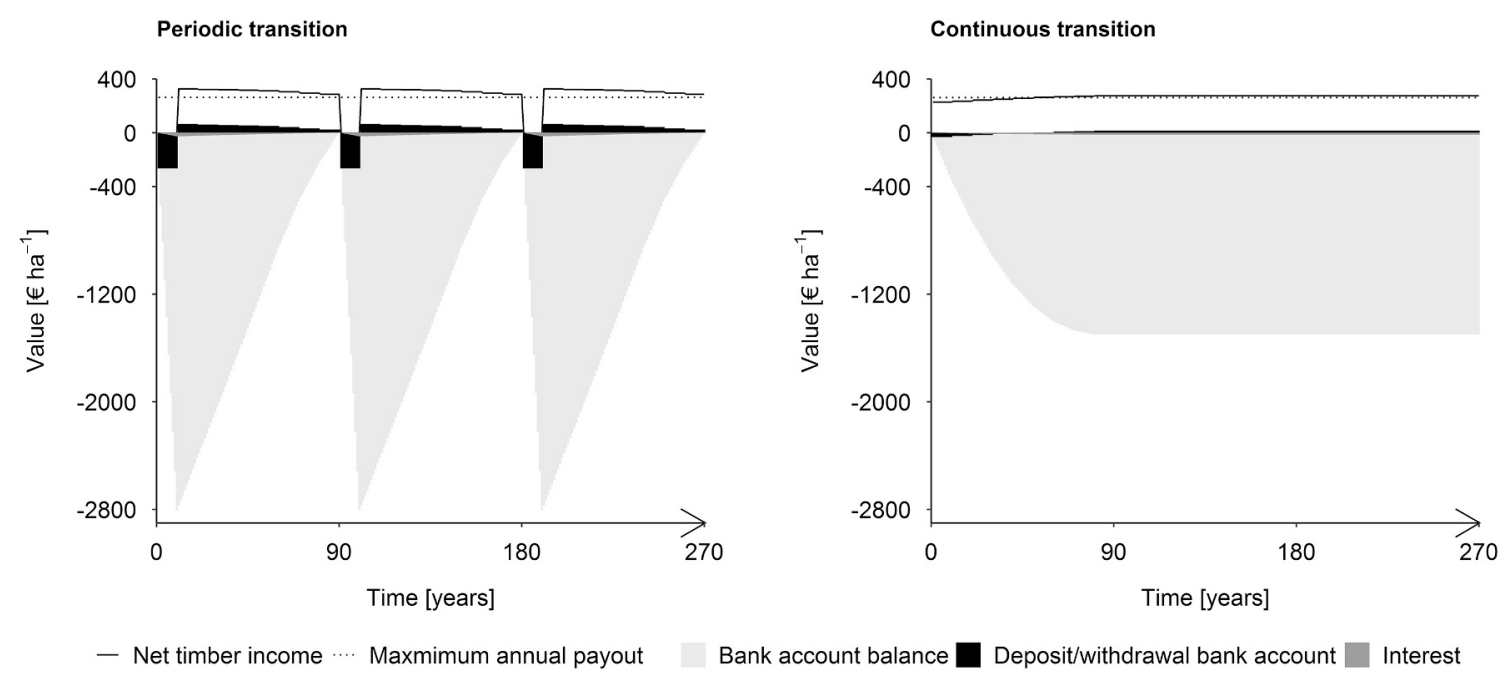

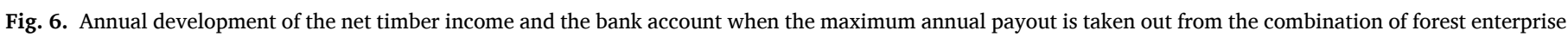
and financial investment.

timer income is turned into a 90-year cycle of irregular income which repeats in perpetuity.

During the first four decades of the continuous transition, the net timber income from thinning and final harvest of a smaller portion of forest stands is now lower than the initial net timber income but still positive. After 80 years, as the continuous transition is completed, the forest enterprise reaches its highest net timber income in a new normal forest of 90 years.

\subsection{Perfect capital market}

\subsubsection{Net present value and annuity of net timber income}

For the infinite stream of net timber income illustrated in Fig. 5, the NPV and the annuity is calculated at a $1 \%$ interest rate (see Table 4).

Compared to the NPV of the initial state, both the periodic and continuous transition lead to an increase in NPV, which indicates the financial benefit from increasing the rotation age from 80 to 90 years at an interest rate of $1 \%$. The periodic transition following the FPOharvesting-pattern is however economically favorable compared to the continuous transition. These results are conforming to investment theory as NPV/annuity of the cash flow is higher when only mature stands are harvested (see Mitra and Wan, 1985). Immature harvest in the case of the continuous transition lead to an overall lower economic performance on a perfect capital market due to inefficient investment and financing costs.

The results also illustrate a key element behind Fisher's separation theorem, as the profitability of the investment can be determined without defining an investment objective or considering consumption/ income preferences as maximized wealth (NPV) coincides with maximized income (annuity).

\subsubsection{Maximum annual payout from investment}

While still within the perfect capital market framework, we add the aspect of an alternative external source/sink for financing/investing (debit/credit bank account) with a fixed 1\% interest rate for borrowing and lending capital, as described in section 2.4. The objective is to illustrate the conformity between the maximum annual payout (taken out from the combination of forest enterprise and bank account) and the annuity of the net timber income of the forest enterprise transitions (as of Table 4). Since the maximum annual payout is the amount that can be taken out of the investment without jeopardizing the investments ability to produce this payout, we are looking for the monetary amount that can be taken out of the investment so that the combination of forest enterprise and bank account reach a state of equilibrium in an infinite time horizon. Table 5 shows the development of the forest enterprise and the bank account of the periodic transition (top) and continuous transition (bottom). In Table 5 (lines 1-8 and 14-21) the initial state of the 80-year normal forest enterprise can be seen on the left-hand side (as of Table 3 in section 2.3). Below the forest enterprise (Table 5, lines $10-13$ and 23-26), is the bank account with an initial starting capital of $0.00 €$. Figuratively in between the two (Table 5, lines 9 and 22) is the maximum annual payout (i.e. the annuity of net timber income as of Table 4).

Moving from left to right in Table 5, the transitions of the forest enterprise and the corresponding movements in the bank account develop. Each year the same monetary amount is payed-out from the combined investment. When the net timber income of the forest enterprise is lower than the annual payout, it is compensated with capital taken from the bank account. Alternatively, if the annual payout is lower than the net timber income, the income surplus is invested into the bank account. For the periodic transition, the bank account balance (Table 5, line 13) fluctuates strongly due to no timber income during the first 10 years and goes back to $0.00 €$ after 90 years and the next rotation begins. The bank account balance for the continuous transition (Table 5, line 26) decreases moderately and reaches $-1500 € \mathrm{ha}^{-1}$ where it remains in perpetuity. The interest rates (Table 5, lines 11 and 24) are constant at $1 \%$. Both states of equilibrium of the combination of the forest enterprise and the bank account are visualized in Fig. 6.

In section 2.2 we mentioned that the net soil rent as an annuity is the monetary amount that can be annually withdrawn from the forest stand development and that this annuity at $0 \%$ interest is equal to the net timber income of the normal forest enterprise. When the regular flow of net timber income is repeatedly or temporary disrupted-as in case of the two forest enterprise transitions-a new annuity can be calculated from the stream of net timber income. This annuity corresponds to the maximum monetary amount annually withdrawn, i.e. the maximum annual payout. Again the periodic transition following the FPOharvesting-pattern is economically more profitable. The large income gaps are simply funded by the bank account so that no immature stands need to be harvested to guarantee the maximum annual payout.

\subsection{Imperfect capital market}

\subsubsection{Maximum annual payout from investment}

Next we apply the imperfect capital market model of section 2.4 (Fig. 3 and Eq. (2)) to the forest enterprise transitions and calculate the 


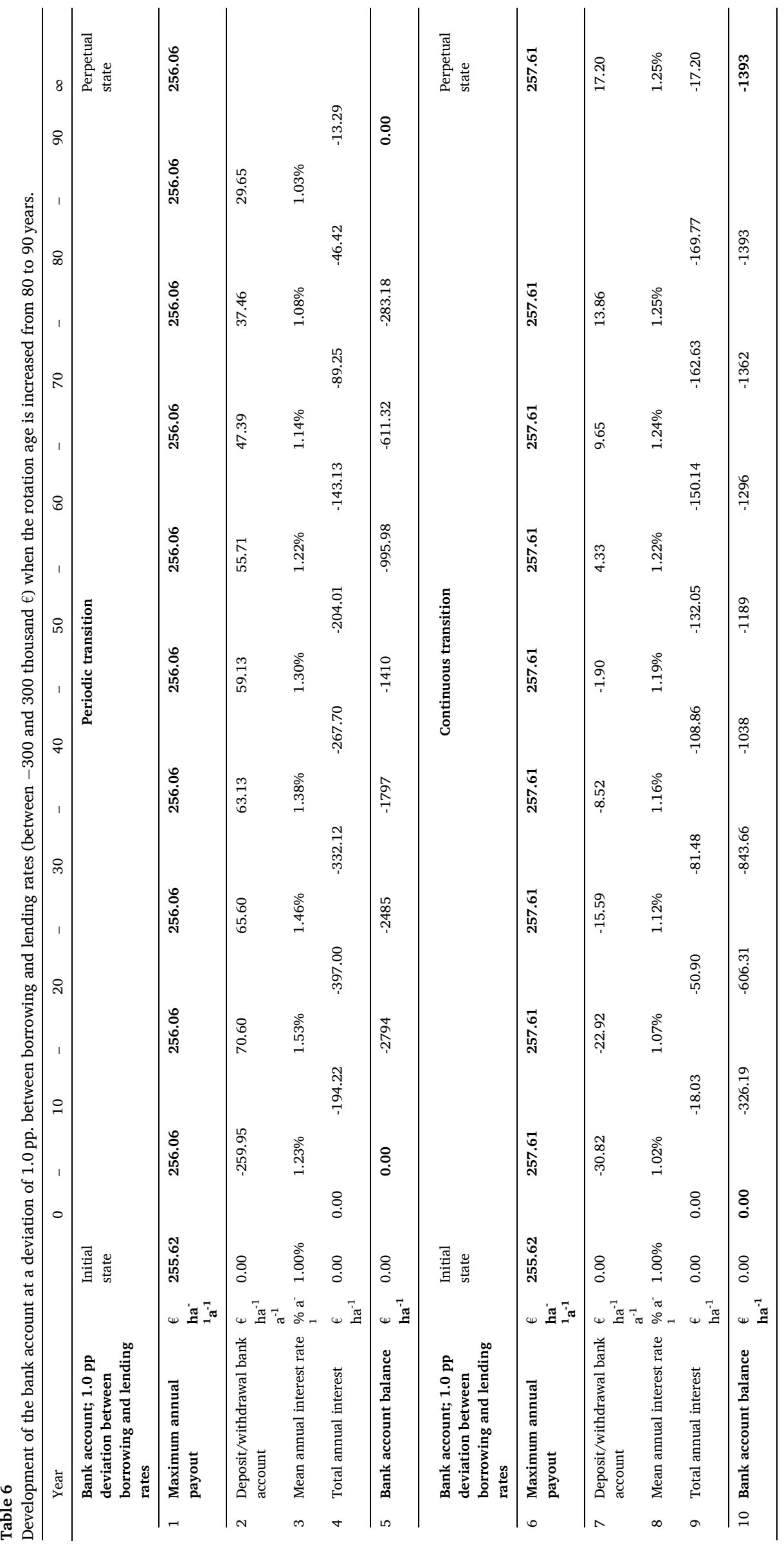




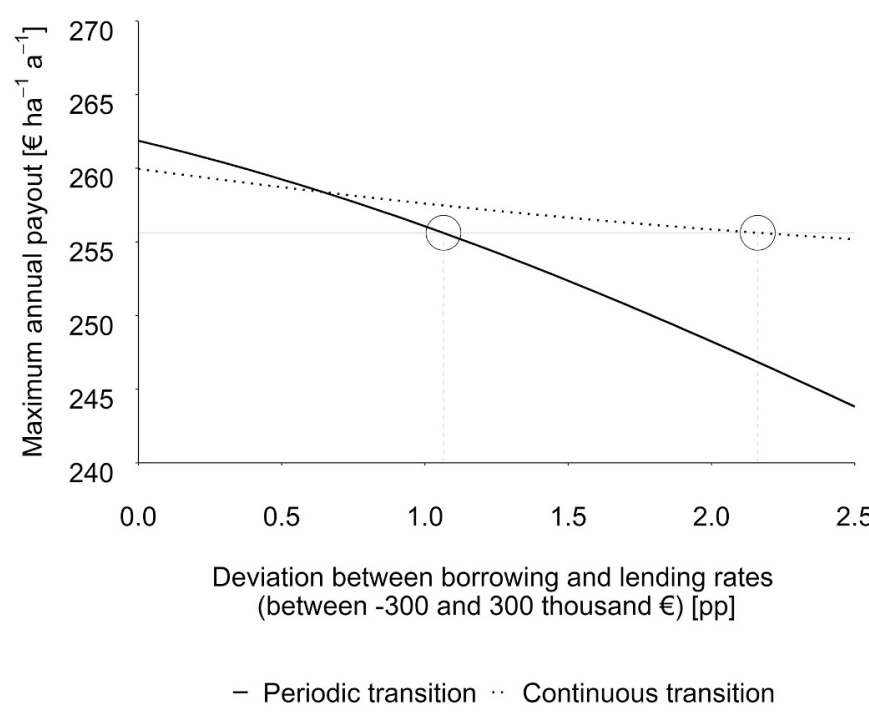

Fig. 7. Maximum annual payout from the periodic and continuous transition. The deviation between borrowing and lending rates between -300 and 300 thousand $€$ indicate the degree of capital market imperfection starting from a $0.00 \mathrm{pp}$ deviation (perfect capital market). The horizontal gray line indicates the initial maximum annual payout of $255.62 € \mathrm{ha}^{-1} \mathrm{a}^{-1}$ prior to transition. The circles indicate the point until the transitions no longer increase profitability.

maximum annual payout just as in section 3.3.2. As there are infinite intensities or degrees of capital market imperfection, we illustrate the development of the bank account for an exemplary deviation between borrowing and lending rates (between -300 and 300 thousand euros) of $1.0 \mathrm{pp}$ in Table 6.

The annual interest rates in Table 6 (lines 3 and 8) are no longer constant at $1 \%$ but are determined endogenously depending on the bank account balance of the previous year. The interest rate (line 3) and the interest payment (line 4) of the periodic transition are more volatile than for the continuous transition (lines 8 and 9). However, even at an interest rate deviation of $1.0 \mathrm{pp}$, both transitions yield a higher maximum annual payout compared to the initial situation prior to transition. Identical to our calculations in Table 6 , we calculate the maximum annual payout for all degrees of capital market imperfection, starting from a $0.0 \mathrm{pp}$ deviation between interest rates (perfect capital market) up to a 2.5 pp deviation. Fig. 7 shows the maximum annual payout for each degree of capital market imperfection.

Fig. 7 shows that with increasing deviation between the borrowing and lending rates the maximum annual payout decreases for both the periodic as well as the continuous transition. In the perfect capital market (at a $0.00 \mathrm{pp}$ deviation between the borrowing and lending rates), the maximum annual payout of both transitions is equal to the annuity and the periodic transition is advantageous. The maximum annual payout decreases for both transitions because the mean interest on borrowed capital increases in an unbiased manner. However, already at a small deviation of approximately $0.5 \mathrm{pp}$, the maximum annual payout of the continuous transition becomes more favorable compared to the periodic transition. As the deviation between interest rates continues to increase, the maximum annual payout of the periodic transition drops below the initial maximum annual payout prior to transition. At this point, the decision to transform the forest enterprise from 80 to 90 years would no longer be rational. The continuous transition remains profitable even at greater deviations between borrowing and lending rates, but eventually drops below the initial maximum annual payout as well.

Our results show, that the premise of constant interest rates in the perfect capital market is responsible for the profitability of the periodic transition with irregular timber income. If we relax this assumption even to a small degree (already at a deviation of approximately $0.5 \mathrm{pp}$. between the here relevant borrowing and lending rates) the continuous transition with a long-term constant flow of timber income becomes economically more favorable. This illustrates, that the capital market assumptions have a substantial influence on the relative profitability of alternative forest management regimes.

\section{Discussion and concluding remarks}

\subsection{Discussion of results}

The aim of the study was to support the statement that the profitability of irregular timber income associated with following the FPOrule of optimal timber maturity is conditional to the assumption of constant interest rates within the model of a perfect capital market.

In this regard, we examined the profitability of a periodic versus a continuous forest enterprise transition of a normal forest enterprise towards an increasing forest stand rotation age that maximizes net soil rent (or LEV). Our results show that the periodic transition is economically advantageous in terms of NPV/annuity of net timber income when we assume an exogenous constant interest rate within a perfect capital market. The continuous transition also yields an economically profitable flow of income compared to the initial enterprise state, but it isn't as favorable as forest stands are harvested too early (inefficient financing costs) for the sake of creating the new normal forest structure. In a second step, we extended the forest enterprise model and introduced an external source for financing and investment. This was done to illustrate the question of where the capital to finance the forest enterprise transitions is coming from. The combination of the forest enterprise and the bank account allowed us to show the consistency between the annuity of net timber income and the maximum annual payout from the combination of forest enterprise and bank account.

Because of the lower NPV/annuity when creating a normal forest structure, within the scope of a perfect capital market, it is often considered to be a "costly" restriction which comes at the price of diminishing income. The aim of this paper was therefore to shift the capital market perspective from the perfect capital market, with a constant interest rate, to the imperfect capital market with non-constant interest rates, to resolve the contradiction between sustainability and economic profitability. In this context the literature often refers to "incentives" to smooth forest income (see Tahvonen and Viitala, 2006). In our interpretation, this "incentive" is rather a more realistic assumption towards the capital market. By introducing differing borrowing and lending rates, which are dependent on capital availability, the investment is no longer separated from the financing source. The relevant interest rate becomes an endogenous value within a general equilibrium problem, where financing and investing are interdependent.

In this context it should be mentioned, that the applied model can run into a minor conflict within the imperfect capital market scenario: The initial incentive to transform the forest enterprise is a consequence of the interest rate of $1 \%$ as a constant guiding price for the investor within the perfect capital market (see Hering, 2017, p. 3 f.). Applying the model of the imperfect capital market, where the costs for financing increase and the interest on invested capital decreases dependent on capital availability, the profitability to transform the forest enterprise 
from 80 to 90 years decreases and possibly becomes unprofitable. As the maximum annual payout shifts below the initial maximum annual payout (in our example of $255.62 € \mathrm{ha}^{-1} \mathrm{a}^{-1}$, see Fig. 7), increasing the rotation age from 80 to 90 years would not be economical and the forest enterprise would be better off with keeping the initial rotation age. The most important insight of this analysis is, however, that the continuous transition from 80 to 90 years becomes-in comparison-increasingly favorable compared to the periodic transition (relative profitability). This means, the more imperfect the capital market gets, the more favorable the continuous transition becomes. The continuous transition also remains economically favorable longer (compared to the initial state) as the capital market imperfection increases. This shows, that the normal forest structure and a steady flow of income is beneficial in a financial environment which describes reality more closely.

\subsection{Implications of results for self-financing}

It is worth noting, that the observed fundamental results of our analysis can be transferred to a situation where capital is partially borrowed "out of the own pocket" in addition to an external source of funding. Imagine for example that the starting budget of the normal forest enterprise is 50 thousand euros, which are initially invested in a bank account at our given capital-volume dependent interest rate function (Eq. (2) and Fig. 3). Because of the extra 50 thousand euros, the maximum annual payout is larger compared to the initial situation where the starting budget is 0 within the perfect capital market (compare Fig. 7 and Fig. A1 at a 0.00 pp deviation between borrowing and lending rates). As the capital market becomes increasingly imperfect, the maximum annual payout decreases (Fig. A1). The relative profitability of the continuous transition now occurs at a greater deviation between borrowing and lending rates (between the relevant -300 and 300 thousand euros) (compare Fig. 7 and Fig. A1). For both transitions the capital costs (interest rate and corresponding payments) are reduced due to the starting budget. However, as the periodic transition sill requires a larger amount of capital to be borrowed compared to the continuous transition (Table A1, lines 2 and 7), the continuous transition becomes more profitable.

\subsection{Model limitations and concluding remarks}

We are aware that the model is still very limited by assumptions that are far away from describing actual capital and timber market conditions. The model still assumes that there is no restriction to the amount of capital borrowed (there is merely a price). The model also assumes the simplified condition of a constant environment meaning that timber growth and prices are constant. Biotic or market risk are also not considered in the model. Despite its simplicity, the applied model and analysis is suitable to achieve the initial aim and scope of this study, which was to support our statement in the introduction section. It becomes apparent that the profitability of irregular timber income is conditional to the perfect capital market assumption. Regular timber income can become more profitable when capital-volume dependent interest rates are considered in the forest stand establishment and harvesting decision.

\section{Funding}

The study was funded in support of academic qualification at the University of Göttingen.

\section{Declaration of Competing Interest}

None.

\section{Acknowledgements}

We would like to thank Dr. Roman Koster and Jasper Fuchs (M.Sc.) for their contribution to the forest model as well as Dr. Kai Husmann and the reviewers for helpful corrections and comments improving the quality of our manuscript. We thank the supervising editor and the editorial team for their professional support throughout the publication process.

\section{Appendix A}

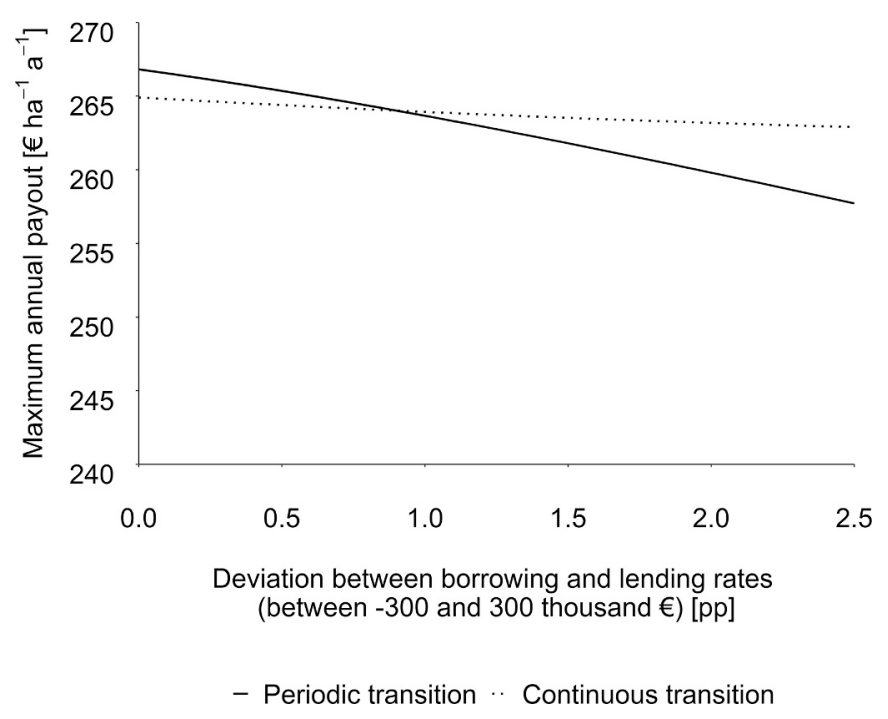

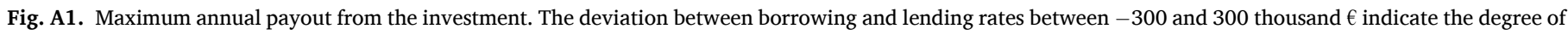
capital market imperfection starting from a $0.00 \mathrm{pp}$ deviation (perfect capital market). 
章

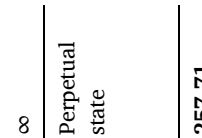

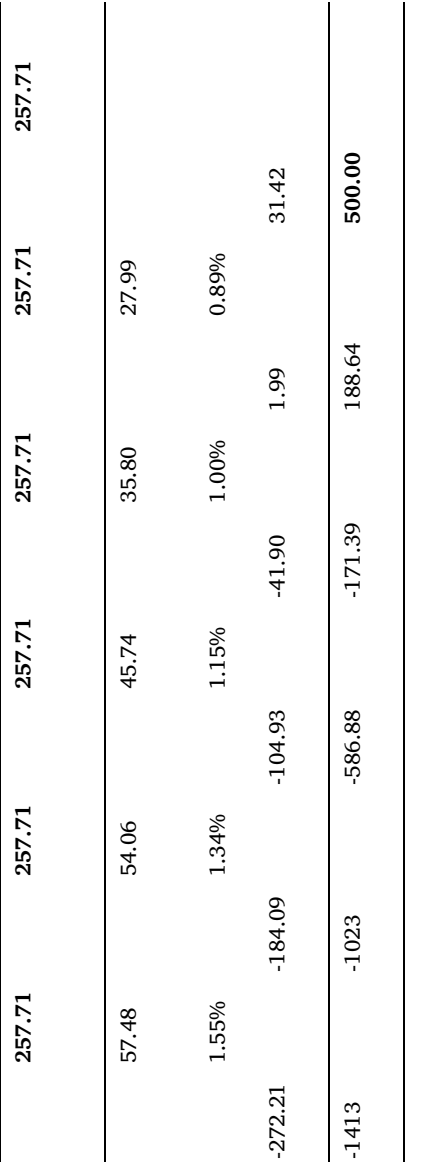

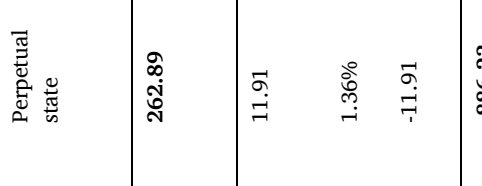

这

$i$

:

跣

ํㅡㅇ

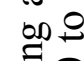

달.

要

可

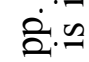

(n)

के

政

$\circ$

, '

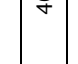

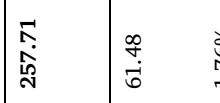

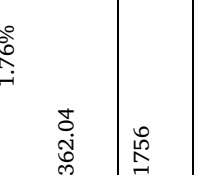

:.

ֻูป

高

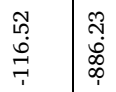

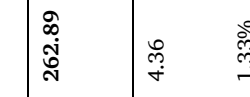

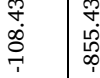

ไู่

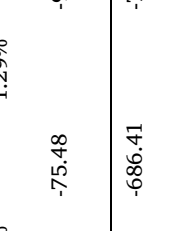

बें

กิ

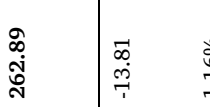

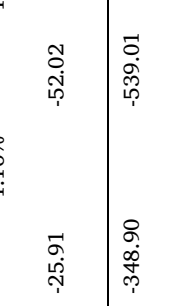

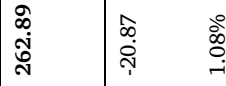

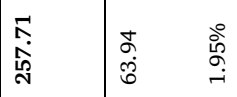

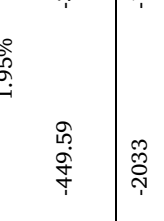

每

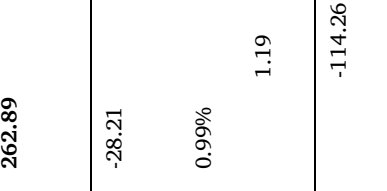

of

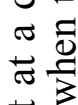

妾空

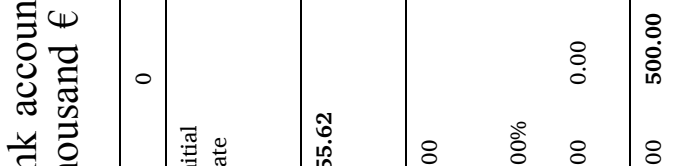

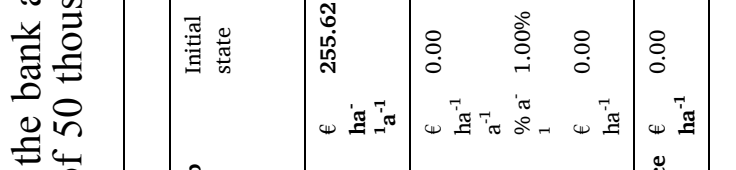

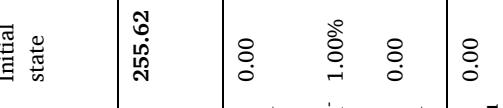

政

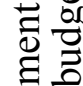

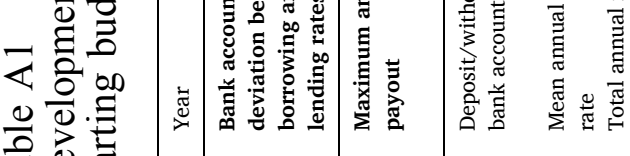

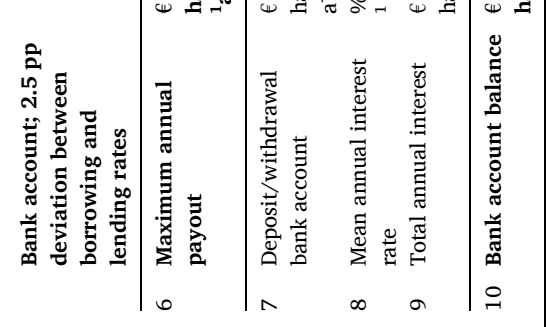




\section{References}

Aronsson, T., Löfgren, K.-G., 1999. Renewable resources: forestry. In: van den Bergh, J.C. J.M. (Ed.), Handbook of Environmental and Resource Economics. Edward Elgar Publishing. Cheltenham, Northampton, MA, pp. 122-140.

Binkley, C.S., 1981. Timber Supply from Private Nonindustrial Forests: A microeconom. Analysis of Landowner Behavior. Yale University, New Haven, p. 97.

Bodelschwingh, H.v., 2018. Ökonomische Potentiale von Waldbeständen. J. D. Sauerländer's Verlag, Bad Orb, p. 241.

Brazee, R.J., 2003. The Volvo theorem: from myth to behavior model. In: Helles, F., Strange, N., Wichmann, L. (Eds.), Recent Accomplishments in Applied Forest Economics Research, Vol. 74. Springer Netherlands, Dordrecht, pp. 39-48.

Brazee, R., Mendelsohn, R., 1988. Timber harvesting with fluctuating prices. For. Sci. 34 (2), 359-372. https://doi.org/10.1093/forestscience/34.2.359.

Comolli, P.M., 1981. Principles and policy in forestry economics. Bell J. Econ. 12 (1), 300-309. https://doi.org/10.2307/3003526.

Faustmann, M., 1849. Berechnung des Werthes, welchen Waldboden, sowie Berechnung des Werthes, welchen Waldboden, sowie noch nicht haubare Holzbestände für die Waldwirtschaft besitzen. Allgemeine Forst- und Jagdzeitung 441-445.

Fisher, I., 1930. The Theory of Interest: As Determined by Impatience to Spend Income and Opportunity to Invest it. Macmillan, New York, p. 566.

Gerst, J., 2015. Der Grenzzins als Entscheidungskriterium in der Forstwirtschaft: Methodisches Konzept und empirische Evidenz. J. D. Sauerländer's Verlag, Bad Orb, p. 120.

Hahn, W.A., Härtl, F., Irland, L.C., Kohler, C., Moshammer, R., Knoke, T., 2014 Financially optimized management planning under risk aversion results in even-flow sustained timber yield. Forest Policy Econ. 42, 30-41. https://doi.org/10.1016/j. forpol.2014.02.002.

Hartman, R., 1976. The harvesting decision when a standing Forest has value. Econ. Inq. 14 (1), 52-58. https://doi.org/10.1111/j.1465-7295.1976.tb00377.x.

Hering, T., 2017. Investitionstheorie, 5th ed. de Gruyter Oldenbourg, Berlin, Boston, p. 461.

Heyer, C., 1841. Die Waldertrags-Regelung. Ferber, Gießen, p. 264.

Hirshleifer, J., 1958. On the theory of optimal investment decision. J. Polit. Econ. 66 (4), 329-352. https://doi.org/10.1086/258057.

Hultkrantz, L., 1991. A note on the optimal rotation period in a synchronized normal forest. For. Sci. 37 (4), 1201-1206. https://doi.org/10.1093/forestscience/ 37.4.1201.

Hundeshagen, J.C., 1826. Die Forstabschätzung auf neuen, wissenschaftlichen Grundlagen, nebst einer Charakteristik und Vergleichung aller bisher bestandenen Forsttaxations-Methoden. In: zwei Abteilungen. Laupp, Tübingen, p. 428.

Johansson, P.-O., Löfgren, K.-G., 1985. The Economics of Forestry and Natural Resources. Basil Blackwell, New York, Oxford, p. 292.

Klemperer, W.D., 1996. Forest Resource Economics and Finance. McGraw Hill, New York, p. 551.

Kruschwitz, L., Lorenz, D., 2019. Investitionsrechnung, 15th ed. de Gruyter Oldenbourg, Berlin, Boston, p. 427.

Kuuluvainen, J., Salo, J., 1991. Timber supply and life cycle harvest of nonindustrial private Forest owners: an empirical analysis of the Finnish case. For. Sci. 37 (4), 1011-1029. https://doi.org/10.1093/forestscience/37.4.1011.

Mitra, T., Wan, H.Y., 1985. Some theoretical results on the economics of forestry. Rev. Econ. Stud. 52 (2), 263-282. https://doi.org/10.2307/2297621.

Möhring, B., 1994. Über ökonomische Kalküle für forstliche Nutzungsentscheidungen: Ein Beitrag zur Förderung des entscheidungsorientierten Ansatzes der forstlichen Betriebswirtschaftslehre. J. D. Sauerländer's Verlag, Frankfurt am Main, p. 217.
Möhring, B., 2001. Nachhaltige Forstwirtschaft und Rentabilitätsrechnung - ein Widerspruch? Allgemeine Forst- und Jagdzeitung 172 (4), 61-66.

Möhring, B., 2010. Optimierung forstlicher Produktion unter Beachtung von finanziellen Restriktionen. Schweiz. Z. Forstwes. 161 (9), 346-354. https://doi.org/10.3188/ szf.2010.0346.

Möhring, B., Dieter, M., 2020. Zins - Fluch oder Segen in der forstlichen Planung? Allgemeine Forst- und Jagdzeitung 190 (5-6), 101-120. https://doi.org/10.23765/ afjz0002041.

Möhring, B., Rüping, U., Leefken, G., Ziegeler, M., 2006. Die Annuität - ein "missing link" der Forstökonomie? Allgemeine Forst- und Jagdzeitung 177 (2), 21-29.

Murphy, P.A., Fortson, J.C., Bethune, J.E., 1977. Timber management decision making under imperfect capital markets. Am. J. Agric. Econ. 59 (2), 302-310. https://doi. org $/ 10.2307 / 1240020$

Newman, D.H., 1988. The Optimal Forest Rotation: A Discussion and Annotated Bibliography. USDA Forest Service, Southeastern Forest Experiment Station, Asheville, NC, p. 50

Norstrøm, C.J., 1975. A stochastic model for the growth period decision in forestry. Swed. J. Econ. 77 (3), 329. https://doi.org/10.2307/3438965.

Oderwald, R.G., Duerr, W.A., 1990. König-Faustmannism: A Critique. For. Sci. 36 (1), 169-174. https://doi.org/10.1093/forestscience/36.1.169.

Ovaskainen, V., 1992. Forest taxation, timber supply, and economic efficiency. Acta Forestalia Fennica (233), 1-88. https://doi.org/10.14214/aff.7679.

Salo, S., Tahvonen, O., 2002a. On equilibrium cycles and Normal forests in optimal harvesting of tree vintages. J. Environ. Econ. Manag. 44 (1), 1-22. https://doi.org/ 10.1006/jeem.2001.1224.

Salo, S., Tahvonen, O., 2002b. On the optimality of a normal forest with multiple land classes. For. Sci. 3 (48), 530-542. https://doi.org/10.1093/forestscience/48.3.530.

Samuelson, P.A., 1976. Economics of forestry in an evolving society. Econ. Inq. 14 (4), 466-492. https://doi.org/10.1111/j.1465-7295.1976.tb00437.x.

Schober, R., 1995. Ertragstafeln wichtiger Baumarten bei verschiedener Durchforstung, 4th ed. J. D. Sauerländer's Verlag, Frankfurt am Main, p. 166.

Smaltschinski, T., 2001. Regionale Waldwachstumsprognose. Schriftenreihe Freiburger forstliche Forschung. Forstwissenschaftliche Fakultät der Universität Freiburg, Forstliche Versuchs- und Forschungsanstalt Baden-Württemberg, Freiburg, p. 121.

Speidel, G., 1972. Planung im Forstbetrieb: Grundlagen und Methoden der Forsteinrichtung. Parey, Hamburg, p. 267.

Spellmann, H. (Ed.), 2017. Nachhaltiges Landmanagement im Norddeutschen Tiefland. Beiträge Aus Der Nordwestdeutschen Forstlichen Versuchsanstalt. Universitätsverlag Göttingen, Göttingen, p. 432.

Tahvonen, O., 1998. Bequests, credit rationing and in situ values in the FaustmannPressler-Ohlin forestry model. Scand. J. Econ. 100 (4), 781-800. https://doi.org/ 10.1111/1467-9442.00136.

Tahvonen, O., Viitala, E.-J., 2006. Does Faustmann rotation apply to fully regulated forests? For. Sci. 52 (1), 23-30. https://doi.org/10.1093/forestscience/52.1.23.

Tahvonen, O., Salo, S., Kuuluvainen, J., 2001. Optimal forest rotation and land values under a borrowing constraint. J. Econ. Dyn. Control. 25 (10), 1595-1627. https:// doi.org/10.1016/S0165-1889(99)00065-2.

Uusivuori, J., Kuuluvainen, J., 2001. Benefits of Forest-owner collaboration and imperfect capital markets. For. Sci. 47 (3), 428-436. https://doi.org/10.1093/ forestscience/47.3.428.

Wiedemann, E. 1936/42. Ertragstafel für die Baumart Fichte. In: Schober, R. (Ed.), Ertragstafeln wichtiger Baumarten bei verschiedener Durchforstung, 4th ed. J. D. Sauerländer's Verlag, Frankfurt am Main. 


\section{Complete list of references}

Arnim, G. v. (2020). Finanzierung in privaten forstbetrieben bei kalamität [Master's thesis]. GeorgAugust-Universität Göttingen, Göttingen

Arnim, G. V., Möhring, B., \& Paul, C. (2021, unpublished). Constrained liquidity in times of forest disturbances: A study on adaptation in private forest enterprises in Germany. Austrian Journal of Forest Science (under review).

Arnim, G. V., Wildberg, J., \& Möhring, B. (2020, July 10). Liquiditätssicherung privater forstbetriebe bei kalamität. Holz-Zentralblatt, 146(28), pp. 520-521.

Aronsson, T., \& Löfgren, K.-G. (1999). Renewable resources: Forestry. In J. C. J. M. van den Bergh (Ed.), Handbook of environmental and resource economics (pp. 122-140). Edward Elgar Publishing. https://doi.org/10.4337/9781843768586.00019

Beinhofer, B. (2009). Zur Anwendung der Portfoliotheorie in der Forstwissenschaft - Finanzielle Optimierungsansätze zur Bewertung von Diversifikationseffekten [Doctoral thesis]. Technische Universität München, Freising.

Binkley, C. S. (1981). Timber Supply From Private Nonindustrial Forests: A Microeconomic Analysis of Landowner Behavior. Yale School of Forestry and Environmental Studies Bulletin Series. 7.

BMEL. (October 2014). Der Wald in Deutschland: Ausgewählte Ergebnisse der dritten Bundeswaldinventur. Berlin. Bundesministerium für Ernährung und Landwirtschaft. https://www.bmel.de/SharedDocs/Downloads/DE/Broschueren/bundeswaldinventur3.pdf;jse ssionid=76F3A9CC26DD9D4764290652369B8C69.live832?_blob=publicationFile \&v=3

BMEL. (December 2016). Ergebnisse der Bundeswaldinventur 2012. Berlin. Bundesministerium für Ernährung und Landwirtschaft. https://www.bundeswaldinventur.de/fileadmin/SITE_MASTER/content/Downloads/BMEL_B WI_Bericht_Ergebnisse_2012_RZ02_web-4.pdf

BMEL. (September 2017). Waldbericht der Bundesregierung 2017. Bonn. Bundesministerium für Ernährung und Landwirtschaft. https://www.bmel.de/SharedDocs/Downloads/DE/Broschueren/Waldbericht2017.pdf;jsessio nid=148CE6708F67FC3B9CC034980A907F73.live832?_blob=publicationFile\&v=3

BMEL. (January 2018). Die wirtschaftliche Lage der forstwirtschaftlichen Betriebe: Buchführungsergebnisse des Forstwirtschaftsjahres 2016. Bonn. Bundesministerium für Ernährung und Landwirtschaft. https://www.bmel-statistik.de/fileadmin/daten/BFB-01130022016.pdf

Bodelschwingh, H. v. (2018). Ökonomische Potentiale von Waldbeständen: Konzeption und Abschätzung im Rahmen einer Fallstudie in hessischen Staatswaldflächen. Schriften zur Forst- und Umweltökonomie: Vol. 47. J. D. Sauerländer's Verlag.

Bolte, A. (2016). Chancen und risiken der buche im klimawandel. AFZ-DerWald, 71(12), 17-19.

Bolte, A., Hilbrig, L., Grundmann, B., Kampf, F., Brunet, J., \& Roloff, A. (2010). Climate change impacts on stand structure and competitive interactions in a southern swedish spruce-beech forest. European Journal of Forest Research, 129(3), 261-276. https://doi.org/10.1007/s10342-0090323-1 
Borchert, H. (2002). The Economically Optimal Amount of Timber Cut in Forests: An approach by Control Theory. Schriften zur Forstökonomie: Vol. 24. J. D. Sauerländer's Verlag.

Borchert, H. (2004). Ökonomische folgen des trockenjahres 2003 und kosten des waldumbaus. LWF Aktuell, 43, 31-32.

Brandl, H. (2002). The economic situation of family-farm enterprises in the southern black forest. Small-Scale Forestry, 1(1), 13-24. https://doi.org/10.1007/s11842-002-0002-2

Brandl, H. (2011). Experiences in collecting data on farm forest enterprises over more than three decades. Small-Scale Forestry, 10(2), 135-147. https://doi.org/10.1007/s11842-011-9158-y

Brazee, R. (2003). The volvo theorem: From myth to behavior model. In F. Helles, N. Strange, \& L. Wichmann (Eds.), Forestry Sciences: Vol. 74. Recent Accomplishments in Applied Forest Economics Research (pp. 39-48). Springer. https://doi.org/10.1007/978-94-017-0279-9_3

Brazee, R., \& Mendelsohn, R. (1988). Timber harvesting with fluctuating prices. Forest Science, 34(2), 359-372. https://doi.org/10.1093/forestscience/34.2.359

Brockwell, P. J., \& Davis, R. A. (2016). Introduction to Time Series and Forecasting (3rd ed.). Springer Texts in Statistics. Springer International Publishing. https://doi.org/10.1007/978-3-319-298542

Brunette, M., Dragicevic, A., Lenglet, J., Niedzwiedz, A., Badeau, V., \& Dupouey, J.-L. (2014). Portfolio management of mixed-species forests, [University works] auto-saisine. hal-01589694

Bürgi, P., \& Pauli, B. (2012). Schweizer waldwirtschaft vor großen herausforderungen. Wald Und Holz, 93(5), 19-21.

Bürgi, P., Sekot, W., Ermisch, N., Pauli, B., Möhring, B., \& Toscani, P. (2016). Forstbetrieblicher kennzahlenvergleich deutschland - österreich - schweiz [forest enterprise key figure comparison Germany - Austria - Switzerland]. Schweizerische Zeitschrift Für Forstwesen, 167(2), 73-81. https://doi.org/10.3188/szf.2016.0073

Cheng, P., \& Roulac, S. E. (2007). Measuring the effectiveness of geographical diversification. The Journal of Real Estate Portfolio Management, 13(1), 29-44.

Choueifaty, Y., \& Coignard, Y. (2008). Toward maximum diversification. The Journal of Portfolio Management, 35(1), 40-51. https://doi.org/10.3905/JPM.2008.35.1.40

Clasen, C., Griess, V. C., \& Knoke, T. (2011). Financial consequences of losing admixed tree species: A new approach to value increased financial risks by ungulate browsing. Forest Policy and Economics, 13(6), 503-511. https://doi.org/10.1016/j.forpol.2011.05.005

Comolli, P. M. (1981). Principles and policy in forestry economics. The Bell Journal of Economics, 12(1), 300-309. https://doi.org/10.2307/3003526

Dög, M., \& Möhring, B. (2017). Ergebnisse des forstlichen privatwald-betriebsvergleichs westfalenlippe im jahr 2016. Die Waldbauern in NRW, 6, 14-15.

Dög, M., Möhring, B., \& Wrede, E. v. (2016). Der privatwald-betriebsvergleich westfalen-lippe im wj 2015. AFZ-DerWald, 71(23), 32-34. 
Dög, M., Möhring, B., Wrede, E. v., \& Ellermann, W. (2017). Privatwald-betriebsvergleich westfalenlippe im jahr 2016. AFZ-DerWald, 72(23), 31-33.

Dög, M., Wildberg, J., \& Möhring, B. (2018). Analysis of a long-term forest accountancy network to support management and controlling. Open Agriculture, 3(1), 155-162. https://doi.org/10.1515/opag-2018-0016

Dragicevic, A., Lobianco, A., \& Leblois, A. (2016). Forest planning and productivity-risk trade-off through the markowitz mean-variance model. Forest Policy and Economics, 64, 25-34. https://doi.org/10.1016/j.forpol.2015.12.010

Ermisch, N., Seintsch, B., \& Dieter, M. (2013). Holzartengruppe fichte 2003 bis 2011 konstant mit höchstem erlösbeitrag. AFZ-DerWald, 68(23), 6-9.

EUWID. (2020, November 5). Schadholz-Prognosen regional deutlich korrigiert [Press release]. Europäischer Wirtschaftsdienst. https://www.euwidholz.de/news/rundholzschnittholz/einzelansicht/Artikel/schadholz-prognosen-regionaldeutlich-korrigiert.html

Faustmann, M. (1849). Berechnung des werthes, welchen waldboden, sowie noch nicht haubare holzbestände für die waldwirtschaft besitzen. Allgemeine Forst- Und Jagdzeitung, 441-445.

Figge, F. (2004). Bio-folio: Applying portfolio theory to biodiversity. Biodiversity and Conservation, 13(4), 827-849. https://doi.org/10.1023/B:BIOC.0000011729.93889.34

Fillbrandt, T. (2005). Das testbetriebsnetz forstwirtschaft als instrument der politik und der betriebsführung.

https://www.waldwissen.net/de/waldwirtschaft/betriebsfuehrung/organisation-undplanung/testbetriebsnetze-in-der-forstwirtschaft

Fisher, I. (1930). The theory of interest: As Determined by Impatience To Spend Income and Opportunity To Invest It. Macmillan.

Gamfeldt, L., Snäll, T., Bagchi, R., Jonsson, M., Gustafsson, L., Kjellander, P., Ruiz-Jaen, M. C., Fröberg, M., Stendahl, J., Philipson, C. D., Mikusiński, G., Andersson, E., Westerlund, B., Andrén, H., Moberg, F., Moen, J., \& Bengtsson, J. (2013). Higher levels of multiple ecosystem services are found in forests with more tree species. Nature Communications, 4, 1340. https://doi.org/10.1038/ncomms2328

Gerst, J. (2015). Der Grenzzins als Entscheidungskriterium in der Forstwirtschaft: Methodisches Konzept und empirische Evidenz. Schriften zur Forst- und Umweltökonomie: Vol. 41. J. D. Sauerländer's Verlag.

Gibson, R. C. (1990). Asset Allocation: Balancing Financial Risk. Dow Jones-Irwin.

Griess, V. C., \& Knoke, T. (2013). Bioeconomic modeling of mixed Norway spruce-European beech stands: Economic consequences of considering ecological effects. European Journal of Forest Research, 132(3), 511-522. https://doi.org/10.1007/s10342-013-0692-3

Gutsche,C.C. (2014). Entwicklung strategischer Marketingkonzepte für Forstbetriebe: Eine zielgruppenspezifische Analyse am Beispiel Hessen-Forst. Schriften zur Forst- und Umweltökonomie: Vol. 40. J. D. Sauerländer's Verlag. 
Hahn, W. A., Härtl, F., Irland, L. C., Kohler, C., Moshammer, R., \& Knoke, T. (2014). Financially optimized management planning under risk aversion results in even-flow sustained timber yield. Forest Policy and Economics, 42, 30-41. https://doi.org/10.1016/j.forpol.2014.02.002

Hanewinkel, M., Cullmann, D. A., Schelhaas, M.-J., Nabuurs, G.-J., \& Zimmermann, N. E. (2013). Climate change May cause severe loss in the economic value of European forest land. Nature Climate Change, 3, 203-207. https://doi.org/10.1038/NCLIMATE1687

Hartman, R. (1976). The harvesting decision when a standing forest has value. Economic Inquiry, 14(1), 52-58. https://doi.org/10.1111/j.1465-7295.1976.tb00377.x

Hering, T. (2017). Investitionstheorie (5th ed.). de Gruyter Oldenbourg.

Heyer, C. (1841). Die Waldertrags-Regelung. Ferber.

Hight, G. N. (2009). A new way to look at correlations: The incremental diversification effect measure. Journal of Indexes, 44-49.

Hight, G. N. (2010). Diversification effect: Isolating the effect of correlation on portfolio risk. Journal of Financial Planning, 23(5), 54-61.

Hirshleifer, J. (1958). On the theory of optimal investment decision. Journal of Political Economy, 66(4), 329-352. https://doi.org/10.1086/258057

Hogg, J. N., \& Jöbstl, H. A. (1997). Zum stand des forstlichen rechnungswesens in einigen europäischen ländern [on the state of forestry accounting in some European countries]. Centralblatt Für Das Gesamte Forstwesen, 114(2/3), 73-95.

Holthausen, N. (2006). Ökonomische Bedeutung und Management von Naturrisiken im Wald: Theoretische Grundlagen und empirische Analysen nach dem Sturm Lothar (1999) in der Schweiz (1st ed.). Schriften aus dem Institut für Forstökonomie der Universität Freiburg: Vol. 26. Verlag des Instituts für Forstökonomie der Universität Freiburg.

Hultkrantz, L. (1991). A note on the optimal rotation period in a synchronized normal forest. Forest Science, 37(4), 1201-1206. https://doi.org/10.1093/forestscience/37.4.1201

Hundeshagen, J. C. (1826). Die Forstabschätzung auf neuen, wissenschaftlichen Grundlagen, nebst einer Charakteristik und Vergleichung aller bisher bestandenen Forsttaxations-Methoden: In zwei Abteilungen. Laupp.

Johansson, P.-O., \& Löfgren, K.-G. (1985). The Economics of Forestry and Natural Resources. Basil Blackwell.

Kaul, R., \& Leefken, G. (2001). Der forstliche betriebsvergleich westfalen-lippe. In Ministerium für Umwelt und Naturschutz, Landwirtschaft und Verbraucherschutz des Landes NordrheinWestfalen (Ed.), 30 jahre forstlicher betriebsvergleich (pp. 5-14). Druck- und Verlagshaus Bitter $\mathrm{GmbH} \& \mathrm{Co}$.

Klemperer, W. D. (1996). Forest Resource Economics and Finance. McGraw Hill.

Knoke, T. (2008). Mixed forests and finance - methodological approaches. Ecological Economics, 65(3), 590-601. https://doi.org/10.1016/j.ecolecon.2007.08.009

Knoke, T. (2009). Die ökonomische zukunft der fichte. LWF Wissen(63), 16-21. 
Knoke, T. (Ed.). (2012). Forstbetriebsplanung als Entscheidungshilfe. Ulmer.

Knoke, T., Ammer, C., Stimm, B., \& Mosandl, R. (2008). Admixing broadleaved to coniferous tree species: A review on yield, ecological stability and economics. European Journal of Forest Research, 127(2), 89-101. https://doi.org/10.1007/s10342-007-0186-2

Knoke, T., Stimm, B., Ammer, C., \& Moog, M. (2005). Mixed forests reconsidered: A forest economics contribution on an ecological concept. Forest Ecology and Management, 213(1-3), 102-116. https://doi.org/10.1016/j.foreco.2005.03.043

Knoke, T., \& Wurm, J. (2006). Mixed forests and a flexible harvest policy: A problem for conventional risk analysis? European Journal of Forest Research, 125(3), 303-315. https://doi.org/10.1007/s10342-006-0119-5

Koellner, T., \& Schmitz, O. J. (2006). Biodiversity, ecosystem function, and investment risk. BioScience, $\quad 56(12), \quad$ 977-985. $\quad$ https://doi.org/10.1641/00063568(2006)56[977:BEFAIR]2.0.CO;2

Kölling, C., Zimmermann, L., \& Walentowski, H. (2007). Klimawandel: Was geschieht mit buche und fichte? AFZ-DerWald, 62(11), 584-588.

Kruschwitz, L., \& Lorenz, D. (2019). Investitionsrechnung (15th ed.). de Gruyter Oldenbourg.

Kuuluvainen, J., \& Salo, J. (1991). Timber supply and life cycle harvest of nonindustrial private forest owners: An empirical analysis of the finnish case. Forest Science, 37(4), 1011-1029. https://doi.org/10.1093/forestscience/37.4.1011

Lehmann, N. (2020, November 20). Schadholz überflutet den holzmarkt. Darum will der bundesrat den einschlag von fichten beschränken. agrarheute. https://www.agrarheute.com/management/betriebsfuehrung/bundesrat-will-holzeinschlagper-verordnung-reduzieren-575570

Lohner, P., Appel, V., Dieter, M., \& Seintsch, B. (2016). Das tbn-forst: Ein datenschatz für die deutsche forstwirtschaft. AFZ-DerWald, 71(17), 10-11.

Lukomnik, J., \& Hawley, J. P. (2021). Moving Beyond Modern Portfolio Theory: Investing That Matters. Routledge.

Markowitz, H. (1952). Portfolio selection. The Journal of Finance, 7(1), 77-91. https://doi.org/10.2307/2975974

Marutani, T. (2010). The effect of site quality on economically optimal stand management. Journal of Forest Economics, 16(1), 35-46. https://doi.org/10.1016/j.jfe.2009.05.001

Matthies, B. D., Jacobsen, J. B., Knoke, T., Paul, C., \& Valsta, L. (2019). Utilising portfolio theory in environmental research - new perspectives and considerations. Journal of Environmental Management, 231, 926-939. https://doi.org/10.1016/j.jenvman.2018.10.049

Mitra, T., \& Wan, H. Y. (1985). Some theoretical results on the economics of forestry. The Review of Economic Studies, 52(2), 263-282. https://doi.org/10.2307/2297621

Möhring, B. (1994). Über ökonomische Kalküle für forstliche Nutzungsentscheidungen: Ein Beitrag zur Förderung des entscheidungsorientierten Ansatzes der forstlichen Betriebswirtschaftslehre. Schriften zur Forstökonomie: Vol. 7. J. D. Sauerländer's Verlag. 
Möhring, B. (2001). Nachhaltige forstwirtschaft und rentabilitätsrechnung - ein widerspruch? Allgemeine Forst- Und Jagdzeitung, 172(4), 61-66.

Möhring, B. (2004). Betriebswirtschaftliche analyse des waldumbaus. Forst Und Holz, 59(11), 523530.

Möhring, B. (2010). Optimierung forstlicher produktion unter beachtung von finanziellen restriktionen. Schweizerische Zeitschrift Für Forstwesen, 161(9), 346-354. https://doi.org/10.3188/szf.2010.0346

Möhring, B., Bitter, A., Bub, G., Dieter, M., Dög, M., Hanewinkel, M., Hatzfeldt, N. G. v., Köhler, J., Ontrup, G., Rosenberger, R., Seintsch, B., \& Thoma, F. (2021, March 5). Schadenssumme insgesamt 12,7 mrd. Euro: abschätzung der ökonomischen schäden der extremwetterereignisse der jahre 2018 bis 2020 in der forstwirtschaft. Holz-Zentralblatt, 9, pp. 155-158.

Möhring, B., Burkhardt, T., Gutsche, C., \& Gerst, J. (2011). Berücksichtigung von überlebensrisiken in den modellen der waldbewertung und der forstlichen entscheidungsfindung. Allgemeine ForstUnd Jagdzeitung, 182(7/8), 160-171.

Möhring, B., \& Dieter, M. (2020). Zins - fluch oder segen in der forstlichen planung? Allgemeine ForstUnd Jagdzeitung, 190(5-6), 101-120. https://doi.org/10.23765/afjz0002041

Möhring, B., \& Dög, M. (2019). Die bedeutung von betriebsvergleichsdaten. AFZ-DerWald, 74(17), 1215.

Möhring, B., \& Mitarbeiter. (2019). Betriebswirtschaftliche planungs- und entscheidungsmethoden: ws 2019/20 [Lecture script]. Georg-August-Universität Göttingen, Göttingen.

Möhring, B., Rüping, U., Leefken, G., \& Ziegeler, M. (2006). Die annuität - ein „missing link“ der forstökonomie? Allgemeine Forst- Und Jagdzeitung, 177(2), 21-29.

Möhring, B., Wilhelm, S., \& Dög, M. (2016). Tbn-daten für betriebssteuerung, forschung und politikberatung. AFZ-DerWald, 71(17), 12-15.

Möhring, B., Wilhelm, S., \& Dög, M. (2018). The relevance of economic data from forest accountancy networks for forest management, research and politics consultation. Small-Scale Forestry, 17(1), 25-40. https://doi.org/10.1007/s11842-017-9373-2

Murphy, P. A., Fortson, J. C., \& Bethune, J. E. (1977). Timber management decision making under imperfect capital markets. American Journal of Agricultural Economics, 59(2), 302-310. https://doi.org/10.2307/1240020

Neuner, S., Albrecht, A., Cullmann, D., Engels, F., Griess, V. C., Hahn, W. A., Hanewinkel, M., Härtl, F., Kölling, C., Staupendahl, K., \& Knoke, T. (2015). Survival of Norway spruce remains higher in mixed stands under a dryer and warmer climate. Global Change Biology, 21(2), 935-946. https://doi.org/10.1111/gcb.12751

Neuner, S., Beinhofer, B., \& Knoke, T. (2013). The optimal tree species composition for a private forest enterprise - applying the theory of portfolio selection. Scandinavian Journal of Forest Research, 28(1), 38-48. https://doi.org/10.1080/02827581.2012.683038

Neuner, S., \& Knoke, T. (2017). Economic consequences of altered survival of mixed or pure Norway spruce under a dryer and warmer climate. Climatic Change, 140(3-4), 519-531. https://doi.org/10.1007/s10584-016-1891-y 
Newman, D. H. (1988). The Optimal Forest Rotation: A Discussion and Annotated Bibliography. Asheville, NC. USDA Forest Service, Southeastern Forest Experiment Station. https://doi.org/10.2737/SE-GTR-48

Norstrøm, C. J. (1975). A stochastic model for the growth period decision in forestry. The Swedish Journal of Economics, 77(3), 329-337. https://doi.org/10.2307/3438965

Oderwald, R. G., \& Duerr, W. A. (1990). König-faustmannism: A critique. Forest Science, 36(1), 169174. https://doi.org/10.1093/forestscience/36.1.169

Önal, H. (1997). Trade-off between structural diversity and economic objectives in forest management. American Journal of Agricultural Economics, 79(3), 1001-1012. https://doi.org/10.2307/1244439

Ovaskainen, V. (1992). Forest taxation, timber supply, and economic efficiency. Acta Forestalia Fennica, 233, 1-88. https://doi.org/10.14214/aff.7679

Panferov, O., Kreilein, H., Meesenburg, H., Eichhorn, J., \& Gravenhorst, G. (2009). Climatic condition at three beech forest sites in central Germany. In R. Brumme \& P. K. Khanna (Eds.), Ecological Studies: Vol. 208. Functioning and Management of European Beech Ecosystems (pp. 13-32). Springer. https://doi.org/10.1007/b82392_3

Perold, A. F. (2004). The capital asset pricing model. Journal of Economic Perspectives, 18(3), 3-24. https://doi.org/10.1257/0895330042162340

Pressler, M. R. (1860). Zur verständigung über den reinertragswaldbau und dessen betriebsideal. Allgemeine Forst- Und Jagdzeitung(36), 41-55.

Pretzsch, H. (2009). Forest Dynamics, Growth and Yield: From Measurement to Model. Springer.

Roessiger, J., Griess, V. C., Härtl, F., Clasen, C., \& Knoke, T. (2013). How economic performance of a stand increases due to decreased failure risk associated with the admixing of species. Ecological Modelling, 255, 58-69. https://doi.org/10.1016/j.ecolmodel.2013.01.019

Salo, S., \& Tahvonen, O. (2002a). On equilibrium cycles and normal forests in optimal harvesting of tree vintages. Journal of Environmental Economics and Management, 44(1), 1-22. https://doi.org/10.1006/jeem.2001.1224

Salo, S., \& Tahvonen, O. (2002b). On the optimality of a normal forest with multiple land classes. Forest Science, 3(48), 530-542. https://doi.org/10.1093/forestscience/48.3.530

Samuelson, P. A. (1976). Economics of forestry in an evolving society. Economic Inquiry, 14(4), 466492. https://doi.org/10.1111/j.1465-7295.1976.tb00437.x

Schober, R. (Ed.). (1995). Ertragstafeln wichtiger Baumarten bei verschiedener Durchforstung (4th ed.). J. D. Sauerländer's Verlag.

Sekot, W. (2008). Interfirm comparison and benchmarking exercises within the framework of a forest accountancy data network. In L. Cesaro, P. Gatto, \& D. Pettenella (Eds.), EFI proceedings: Vol. 55, The multifunctional role of forests - policies, methods and case studies (pp. 161-169). European Forest Institute. 
Sekot, W. (2017). Forest accountancy data networks as a means for investigating small-scale forestry: A European perspective. Small-Scale Forestry, 16(3), 435-449. https://doi.org/10.1007/s11842017-9371-4

Sekot, W., Fillbrandt, T., \& Zesiger, A. (2011). Improving the international compatibility of accountancy data: The 'dach-initiative'. Small-Scale Forestry, 10(2), 255-269. https://doi.org/10.1007/s11842-010-9134-y

Sekot, W., \& Hoffmann, C. (2007). Zur weiterentwicklung des forstlichen betriebsvergleichs mit hilfe der data envelopment analysis [extension of interfirm comparison of forest enterprises by means of data envelopment analysis]. Austrian Journal of Forest Science, 124(1), 37-64.

Selchert, F. W. (1997). Einführung in die Betriebswirtschaftslehre in Übersichtsdarstellungen (6th ed.). Oldenbourg.

Shannon, C. E., \& Weaver, W. (1948). A mathematical theory of communication. The Bell System Technical Journal, 27(3), 379-423. https://doi.org/10.1002/j.1538-7305.1948.tb01338.x

Sharpe, W. F. (1964). Capital asset prices: A theory of market equilibrium under conditions of risk. The Journal of Finance, 19(3), 425-442. https://doi.org/10.2307/2977928

Smaltschinski, T. (2001). Regionale Waldwachstumsprognose. Schriftenreihe Freiburger forstliche Forschung. Forstwissenschaftliche Fakultät der Universität Freiburg, Forstliche Versuchs- und Forschungsanstalt Baden-Württemberg.

Speidel, G. (1967). Forstliche Betriebswirtschaftslehre: Eine Einführung. Verlag Paul Parey.

Speidel, G. (1972). Planung im Forstbetrieb: Grundlagen und Methoden der Forsteinrichtung. Verlag Paul Parey.

Spellmann, H. (Ed.). (2017). Beiträge aus der Nordwestdeutschen Forstlichen Versuchsanstalt: Vol. 18. Nachhaltiges Landmanagement im Norddeutschen Tiefland. Universitätsverlag Göttingen.

Statistisches Bundesamt. (2019). Verbraucherpreisindizes für deutschland: lange reihen ab 1948. https://www.destatis.de/DE/Themen/Wirtschaft/Preise/Verbraucherpreisindex/Publikatione n/Downloads-Verbraucherpreise/verbraucherpreisindex-lange-reihen-pdf5611103.pdf;jsessionid=32DEA7001E239C1BEA605E047F2854D3.live732?_blob=publication File

Tahvonen, O. (1998). Bequests, credit rationing and in situ values in the faustmann-pressler-ohlin forestry model. Scandinavian Journal of Economics, 100(4), 781-800. https://doi.org/10.1111/1467-9442.00136

Tahvonen, O., Salo, S., \& Kuuluvainen, J. (2001). Optimal forest rotation and land values under a borrowing constraint. Journal of Economic Dynamics and Control, 25(10), 1595-1627. https://doi.org/10.1016/S0165-1889(99)00065-2

Tahvonen, O., \& Viitala, E.-J. (2006). Does faustmann rotation apply to fully regulated forests? Forest Science, 52(1), 23-30. https://doi.org/10.1093/forestscience/52.1.23

Toscani, P. (2016). Methodische aspekte und informationspotentiale forstlicher testbetriebsnetze in österreich [Doctoral thesis]. Universität für Bodenkultur Wien, Vienna. 
Toscani, P., \& Sekot, W. (2015). Assessing the economy of small scale farm forestry at the national scale: The case of Austria. Small-Scale Forestry, 14(2), 255-272. https://doi.org/10.1007/s11842-015-9286-x

Toscani, P., \& Sekot, W. (2018). Forest accountancy data networks-a European approach of empirical research, its achievements, and potentials in regard to sustainable multiple use forestry. Forests, 9(4), 220. https://doi.org/10.3390/F9040220

Toscani, P., Sekot, W., \& Holzleitner, F. (2020). Forest roads from the perspective of managerial accounting-empirical evidence from Austria. Forests, 11(4), 378. https://doi.org/10.3390/F11040378

Ungerböck, E., Sekot, W., \& Toscani, P. (2015). Looking beyond timber: Empirical evidence for the diversification of forest enterprises and the profitability of auxiliary activities in Austria. Forest Policy and Economics, 54, 18-25. https://doi.org/10.1016/j.forpol.2014.12.013

Uusivuori, J., \& Kuuluvainen, J. (2001). Benefits of forest-owner collaboration and imperfect capital markets. Forest Science, 47(3), 428-436. https://doi.org/10.1093/forestscience/47.3.428

Wense, W.-H.v.d. (1990). Der Betriebsvergleich in der Forstwirtschaft: Methoden zur Analyse betriebswirtschaftlicher Kennziffern am Beispiel des Privatwaldvergleichs Westfalen-Lippe [Doctoral thesis]. Georg-August-Universität Göttingen, Göttingen.

Wiedemann, E. (1936/42). Ertragstafel für die Baumart Fichte. In R. Schober (Ed.), Ertragstafeln wichtiger Baumarten bei verschiedener Durchforstung. J. D. Sauerländer's Verlag.

Wildberg, J., \& Möhring, B. (2019). Empirical analysis of the economic effect of tree species diversity based on the results of a forest accountancy data network. Forest Policy and Economics, 109, 101982. https://doi.org/10.1016/j.forpol.2019.101982

Wildberg, J., \& Möhring, B. (2021). Continuous timber harvest - costly restriction or profitable $\begin{array}{lllll}\text { solution? Forest Policy and Economics, } 123, & 102349 .\end{array}$ https://doi.org/10.1016/j.forpol.2020.102349

Wilhelm, S., \& Möhring, B. (2014). Der beitrag verschiedener baumarten zum ökonomischen erfolg von forstbetrieben [the contribution of different tree species to the economic success of mixed forest enterprises in a continuously changing environment]. In E. Schiberna \& M. Stark (Eds.), Adaptation in forest management under changing framework conditions (pp.235-247). Foundation for Sustainable Forest Management. 


\section{Eigenständigkeitserklärung}

Hiermit erkläre ich, dass die vorliegende Arbeit ohne unzulässige Hilfe und ohne Benutzung anderer als der angegebenen Hilfsmittel selbstständig angefertigt wurde und dass die aus fremden Quellen direkt oder indirekt übernommenen Gedanken in der Arbeit als solche kenntlich gemacht worden sind. Alle genutzten fremden Quellen sind im Literaturverzeichnis gelistet.

Johannes Wildberg

Göttingen, April 2021 